Evaluation of the Geologic and Hydrologic Factors Related to the Waste-Storage Potential of Mesozoic Aquifers in the Southern Part of the Atlantic Coastal Plain, South Carolina and Georgia

GEOLOGICALSURVEY PROFESSIONAL PAPER 1088
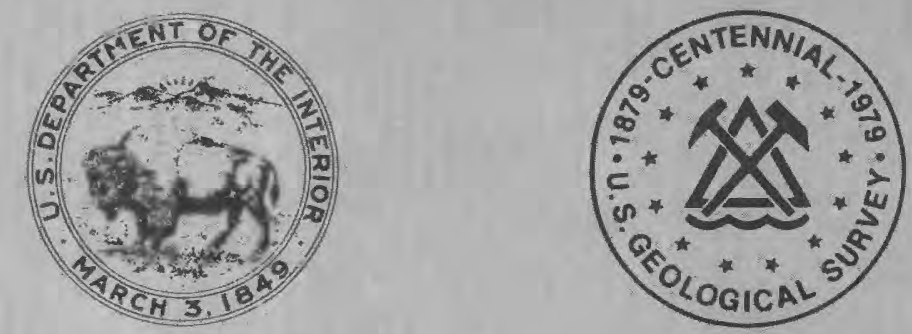


\section{Evaluation of the Geologic and Hydrologic Factors Related to the Waste-Storage Potential of Mesozoic Aquifers in the Southern Part of the Atlantic Coastal Plain, South Carolina and Georgia}

By PHILIP M. BROWN, DONALD L. BROWN, MARJORIE S. REID, and ORVILLE B. LLOYD, JR.

$\begin{array}{lllll}\text { GEOLOGICAL SURVEY PROFESIONAL PAPER } & 1088\end{array}$

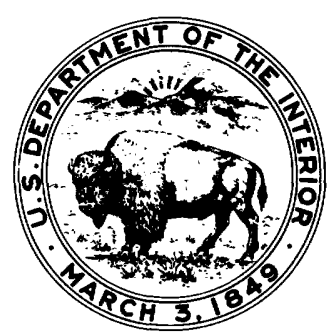




\section{UNITED STATES DEPARTMENT OF THE INTERIOR \\ CECIL D. ANDRUS, Secretary}

\section{GEOLOGICAL SURVEY}

H. William Menard, Director

United States. Geological Survey.

Evaluation of the geologic and hydrologic factors related to the waste-storage potential of Mesozoic aquifers in the southern part of the Atlantic Coastal Plain, South Carolina and Georgia.

(Geological Survey professional paper; 1088)

Includes bibliographical references.

1. Waste disposal in the ground-Southern States. 2. Aquifers--Southern States. I. Brown, Philip Monroe.

II. Title. III. Series: United States. Geological Survey. Professional Paper; 1088.

TD796.7.U55 $1978 \quad 628^{\prime} .445 \quad 78-606091$

For sale by the Superintendent of Documents, U.S. Government Printing Office

Washington, D.C. 20402

Stock Number 024-001-03152-3 


\section{CONTENTS}

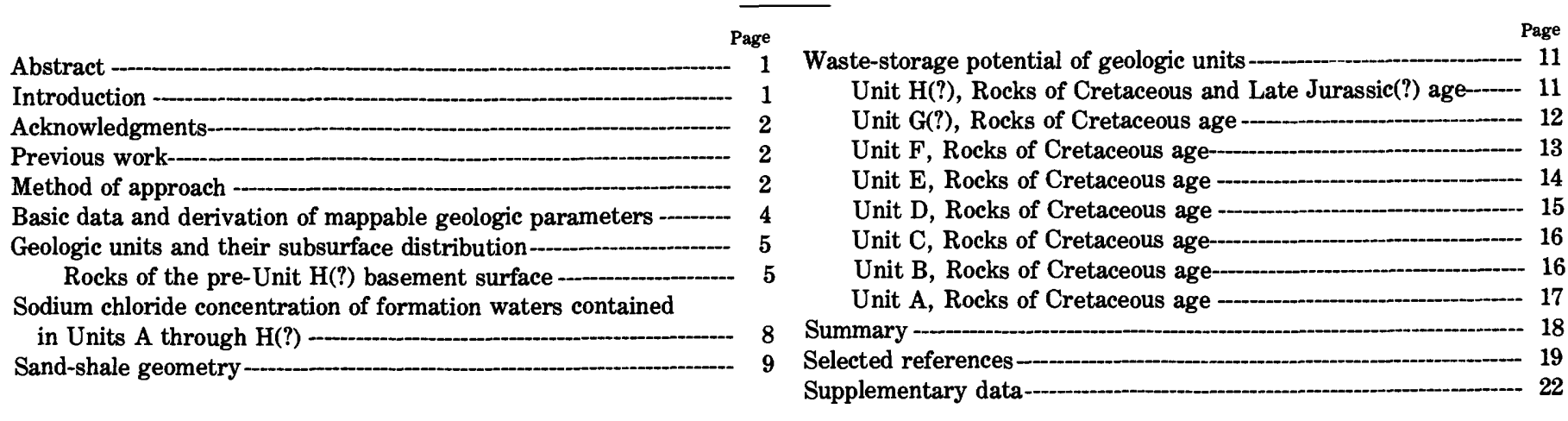

\section{ILLUSTRATIONS}

[Plates are in separate case]

Plate 1. Representative stratigraphic cross sections, Atlantic Coastal Plain, South Carolina and Georgia.

2. Geologic map of the Atlantic Coastal Plain, South Carolina and Georgia.

A. Structural top of the pre-Unit $\mathrm{H}($ ?) basement surface.

B. Thickness, Units $\mathrm{F}$ through $\mathrm{H}(?)$.

C. Thickness, Units A through E.

3. Geohydrologic maps, Unit H(?) of Cretaceous and Late Jurassic(?) age, Atlantic Coastal Plain, South Carolina and Georgia.

A. Structural top of Unit H(?).

B. Thickness and isochlor map, Unit $H(?)$.

C. Sand-shale distribution map, Unit $\mathrm{H}($ ?).

4. Geohydrologic maps, Unit G(?) of Cretaceous age, Atlantic Coastal Plain, South Carolina and Georgia.

A. Structural top of Unit G(?).

B. Thickness and isochlor map, Unit G(?).

C. Sand-shale distribution map, Unit G(?).

5. Geohydrologic maps, Unit F of Cretaceous age, Atlantic Coastal Plain, South Carolina and Georgia.

A. Structural top of Unit F.

B. Thickness and isochlor map, Unit F.

C. Sand-shale distribution map, Unit F.

6. Geohydrologic maps, Unit E of Cretaceous age, Atlantic Coastal Plain, South Carolina and Georgia.

A. Structural top of Unit E.

B. Thickness and isochlor map, Unit E.

C. Sand-shale distribution map, Unit E.

7. Geohydrologic maps, Unit D of Cretaceous age, Atlantic Coastal Plain, South Carolina and Georgia.

A. Structural top of Unit D.

B. Thickness and isochlor map, Unit D.

C. Sand-shale distribution map, Unit D.

8. Geohydrologic maps, Unit C of Cretaceous age, Atlantic Coastal Plain, South Carolina and Georgia.

A. Structural top of Unit C.

B. Thickness and isochlor map, Unit $\mathrm{C}$.

9. Geohydrologic maps, Unit B of Cretaceous age, Atlantic Coastal Plain, South Carolina and Georgia.

A. Structural top of Unit B.

B. Thickness and isochlor map, Unit B.

C. Sand-shale distribution map, Unit B.

10. Geohydrologic maps, Unit A of Cretaceous age, Atlantic Coastal Plain, South Carolina and Georgia.

A. Structural top of Unit A.

B. Thickness and isochlor map, Unit A.

C. Sand-shale distribution map, Unit A. 
PLATE 11. Maps showing distribution of usable and nonusable ground waters in Units A through H(?).

Usable ground-water-sodium chloride values less than $10,000 \mathrm{mg} / \mathrm{L}$.

Nonusable ground-water-sodium chloride values $10,000 \mathrm{mg} / \mathrm{L}$ or greater.

Page

FIGURE 1. Map of project area showing the location of principal structural features - 7

\section{TABLES}

Page

2. Comparative salinity/depth data for Units A through $\mathrm{H}($ ?) in Georgia

3. Number of reservoir sands and wells with waste-storage potential in Units A through $H(?)$ in Georgia

4. Summary of selected data for waste-storage parameters, Units A through $\mathrm{H}($ ?) in Georgia

5. Summary distribution of sand-shale ratio values for Units A through $H(?)$ in Georgia -

6. Well number, name, location, elevation, depth, and stratigraphic data for the 88 wells that make up the key-well network -------22

7. Geohydrologic data for the 18 wells judged to have waste-storage potential -

8. Approximate sodium chloride concentration of ground water in Units A through $\mathrm{H}($ ?) in wells forming the key-well network ---.-. 36 


\title{
EVALUATION OF THE GEOLOGIC AND HYDROLOGIC FACTORS RELATED TO THE WASTE-STORAGE POTENTIAL OF MESOZOIC AQUIFERS IN THE SOUTHERN PART OF THE ATLANTIC COASTAL PLAIN, SOUTH GAROLINA AND GEORGIA
}

\author{
By Philip M. Brown, Donald L. Brown, Marjorie S. Reid, and Orville B. Lloyd, Jr.
}

\begin{abstract}
This report describes the subsurface distribution of rocks of Cretaceous to Late Jurassic(?) age in the Atlantic Coastal Plain, South Carolina, and Georgia, and examines their potential for deep-well waste storage. For mapping purposes, a waste-storage "operational unit" is established and defined. It is a sand or sandstone layer, 20 feet or more in thickness, that is immediately overlain and underlain by a layer of shale or clay, 20 feet or more in thickness, and which occurs in regional chronostratigraphic units (Units A, B, C, D, E, F, G(?), and H(?)) of Mesozoic age in areas where each of these units contains nonusable ground water. Nonusable ground water is defined as water that contains sodium chloride in excess of $10,000 \mathrm{mg} / \mathrm{L}$.

Using a group of geohydrologic parameters derived from or combining 21 categories of basic data, established from study and interpretation of well cuttings and geophysical logs, a series of 32 regional maps and 8 stratigraphic cross sections was constructed. For each of the eight geologic units delineated in the subsurface, the maps illustrate the distribution of waste-storage potential in terms of areal extent, depth below land surface, sand-shale geometry, and the approximate sodium chloride concentration of a unit's nonusable ground water.

In areas where the geologic units contain nonusable ground water, the depth below land surface and the thickness of potential waste-storage reservoir and reservoir-seal combinations are variable. The range in variability appears to be broad enough to meet the need for a wide choice among the geologic requirements that would normally be considered in selecting specific waste-storage sites for detailed examination.
\end{abstract}

\section{INTRODUCTION}

As part of the U.S. Geological Survey's waste-storage research program, a series of studies is being conducted in the Atlantic Coastal Plain. Their purpose is to assess potential for the deep-well emplacement of liquid waste into the part of the regional sediment mass which lies below the deepest zones containing usable ground waters. For purposes of the current study, usable ground water is considered to be that which contains less than $10,000 \mathrm{mg} / \mathrm{L}$ dissolved solids.

South Carolina has a policy that forbids issuing permits for waste injection wells, and no permits have been issued in Georgia (Walker and Cox, 1976, p. 49 and 79).
The U.S. Geological Survey does not advocate that waste be stored in the subsurface, but it does recognize that, in some cases, injection of industrial wastes may be the most environmentally acceptable alternative available to a waste generator or regulator.

This report presents the results of the study conducted in parts of South Carolina and Georgia (fig. 1). The report assesses the region-wide potential for waste storage in the deep subsurface. It contains interpretations and conclusions derived from analysis, synthesis, and extrapolation of structural, stratigraphic, and hydrologic data. These data were obtained from a relatively small number of widely scattered boreholes, chiefly oil tests, in a sparsely drilled region. The study is a continuation of previous studies undertaken in the area extending from New York through North Carolina (See Brown and others, 1972; Brown and Reid, 1976).

In the northern part of the Atlantic Coastal Plain, North Carolina through New Jersey, the geohydrologic conditions are such that the chief waste-storage target sections occur in rocks of Comanchean and Coahuilan age in areas where these rocks lie at depths greater than 1,500 feet below mean sea level (Brown and Reid, 1976). In the southern part of the Atlantic Coastal Plain, South Carolina through Georgia, different geohydrologic conditions prevail. For example, in the southern part some rocks of Gulfian age contain nonusable ground water, whereas to the north they contain usable ground water in onshore areas. Also, and except in a small area in southwestern Georgia, rocks of Coahuilan age are absent and rocks of Comanchean age either have a limited areal distribution or a limited thickness in many areas where they contain nonusable ground waters. Because of the different geohydrologic conditions that prevail in the northern and southern segments of the Atlantic Coastal Plain, Gulfian, as well as Comanchean and Coahuilan, rocks are included in the southern-segment, waste-storage study whereas only Comanchean and Coahuilan rocks were included in the northern-segment study. 


\section{ACKNOWLEDGMENTS}

Frederick M. Swain, project micropaleontologist, studied and identified Ostracoda from selected wells, prepared lists of faunal occurrence and charts of environmental significance, and provided other valuable services that aided the mapping program. Richard N. Benson, project micropaleontologist, provided similar data, with respect to the Foraminifera, as well as other services. George E. Siple, who was assigned to the project for a limited time prior to retirement, prepared location maps and lithologic descriptions for some wells in South Carolina. Among colleagues of the U.S. Geological Survey, Harold Gill and Lin Pollard, Georgia, and Allen Zack, South Carolina, provided well locations and helped to assemble well cuttings and geophysical logs. Joseph Hazel, Paleontology and Stratigraphy Branch, furnished useful data from the Geological Survey's cored section in Dorchester County, South Carolina. Richard Cifelli, U.S. National Museum, made available the unpublished notes and records of the late Esther R. Applin.

Sam M. Pickering, Jr., State Geologist, Earth and Water Division, Georgia Department of Natural Resources, and Norman K. Olson, State Geologist, South Carolina State Development Board, Division of Geology, and members of their staffs, were helpful in making well data available for study.

Most of the cores, cuttings, geophysical logs, and other data used in the study were obtained through the cooperation of several companies that included Chevron Oil Co., Cities Service Oil Co., Exxon Corp., Layne Atlantic Co., Mobil Oil Co., and Sydnor Hydrodynamics, Inc.

\section{PREVIOUS WORK}

In the project area numerous local and multicounty reports have been published that describe and discuss elements of the region's hydrogeologic system. In Georgia, the various publications of P. L. and E. R. Applin and of S. M. Herrick are of particular importance in that they contain the basic elements of interpretive subsurface structure and stratigraphy that customarily have been used by subsequent investigators to describe the subsurface geology of the Georgia Coastal Plain. In South Carolina little quantitative information of mappable quality is available for the deep subsurface. In general, this is due to the lack of deep oil tests, the lack of cores and cuttings from all but a few "key" wells, and obscure or nonexistent well records for many of the deep water wells drilled throughout the South Carolina Coastal Plain. Of the publications that discuss the geology of the project area in a regional context, those of Grover E. Murray, Jr., and John C. Maher are particularly important contributions.
Original accounts and reviews of both local and regional structure and subsurface stratigraphy in the project area include, among others, the publications of Applin and Applin $(1944,1947,1964,1965,1967)$, E. R. Applin (1955), P. L. Applin (1951), Arden (1974), Bonini and Woolard (1960), Bridge and Berdan (1952), Brown (1974), Callahan (1964), Cramer (1969, 1974), Forgotson (1958, 1963), Herrick (1961), Herrick and Vorhis (1963), Hull (1962), King (1961), Maher (1965, 1971), Marine and Siple (1974), Marsalis (1970), McLean (1960), Milton (1954), Milton and Hurst (1965), Milton and Grasty (1969), Murray (1956, 1961), Olson and Glowacz (1977), Patterson and Herrick (1971), Pressler (1947), Prettyman and Cave (1923), Rainwater (1968, 1970a, 1970b), Richards (1945, 1948, 1967), Sever (1964, 1965), Siple (1958, 1959, 1967), Stephenson $(1914,1928)$, and Woolard, Bonini, and Meyer (1957).

Brown, Miller, and Swain (1972) described the structural-stratigraphic framework and spatial distribution of permeability for the northern half of the Atlantic Coastal Plain, New York to North Carolina. Basic data, concepts, and conclusions from that report were used by Brown and Reid (1976) to evaluate the waste-storage potential of selected segments of the Mesozoic aquifer system in the northern half of the Atlantic Coastal Plain. The present report extends and incorporates elements of these two previous reports-it extends into South Carolina and Georgia the Mesozoic segments of the stratigraphic framework described by Brown, Miller, and Swain (1972) and it incorporates the technique used to evaluate waste-storage potential that was introduced and implemented by Brown and Reid (1976).

\section{METHOD OF APPROACH}

In sedimentary basins that may have deep-well, waste-storage potential, a fundamental geologic requirement is the presence, below zones of usable ground water, of porous and permeable strata, that are suffciently thick and capable of receiving a given type and volume of waste, and that are immediately overlain and underlain by relatively impermeable strata, sufficiently thick and capable of retarding the migration of waste into overlying and underlying segments of a ubiquitous hydrologic system. The determinant criteria-position, permeability, and thickness-are mutually applicable to strata that have either reservoir or reservoir-seal potential.

When investigating the geologic potential of specific waste-storage sites in situations where type and volume of waste are known, the geologic information required by management for making an evaluation of each site is obtained by assessment and quantification of data available regionally and from drilling and testing several 
closely spaced, onsite boreholes. When, as in the present case, the problem is to assess the variable geologic potential for waste storage, as it may or may not exist, in a sparsely drilled, multistate area and in situations where type and volume of potential waste are unknown, a different type of exploration technique must be used. One such technique (Brown and Reid, 1976) consists of selecting and defining a widely distributed combination of strata with both reservoir and reservoir-seal potential for a seemingly wide variety of waste types and showing its subsurface distribution and physical attributes by means of maps, charts, and graphs. The purpose of this technique is to screen extensive geographic areas in order to delineate areas that do and do not have wastestorage potential so that limited waste-exploration budgets can be used to best advantage in the areas that have the greatest potential.

In most sedimentary basins several types and combinations of strata with reservoir and reservoir-seal potential can be identified in individual boreholes. The reasons for their occurrence are manifold and often complex in a geologic sense. However, one such combination usually is dominant and widely distributed throughout large segments of any basin. Its dominance and relative widescale distribution are a function of the interaction of tectonic forces and the sedimentologic responses that characterize each particular basin. A reconnaissance study of cuttings and geophysical logs from a few widely scattered wells in a basin generally is sufficient for purposes of recognizing the dominant combination.

From such a reconnaissance study in the project area (fig. 1), the dominant combination of strata with wastestorage potential was judged to consist of porous and permeable sand or sandstone that is immediately overlain and underlain by relatively-impermeable clay or shale. For practical reasons and in consideration of economic and safety constraints, an arbitrary thickness value of 20 feet or more may be assigned to both types of strata that make up the potential reservoir and reservoir-seal combination. Thus, by preliminary definition, the dominant combinations of strata with waste-storage potential in the project area consists of:

\section{A sand or sandstone layer, 20 feet or greater in thickness, that is directly underlain and overlain by a clay or shale layer, 20 feet or greater in thickness.}

A major constraint inherent in the process of delineating potential waste-storage reservoirs within an aquifer system is that the potential reservoirs must lie below zones of usable ground water. The distinction between usable and nonusable ground water generally is based on the amount of dissolved solids present in the water. However, there is no specific value that is generally ac- cepted for dissolved solids which serves to differentiate usable from nonusable ground waters. For purposes of this report, usable ground water is defined as water that contains less than $10,000 \mathrm{mg} / \mathrm{L}$ dissolved solids-a little less than one-third of the approximately $35,000 \mathrm{mg} / \mathrm{L}$ dissolved solids present in sea water.

In the deeply-buried parts of what is essentially a noncarbonate, sand-shale (aquifer-aquiclude) system in the project area, the amount of dissolved solids in ground water is about equivalent to the amount of sodium chloride for all practical purposes. Therefore, it follows that in order for aquifers to have waste-storage potential in the project area, they must contain water with a sodium chloride concentration greater than $10,000 \mathrm{mg} / \mathrm{L}$.

On the basis of their distribution in the subsurface, their sand-shale geometry, and calculation of the sodium chloride concentration of their contained waters, eight geologic units of Mesozoic age were judged to have some possible potential for waste storage in the project area. They are the regional chronostratigraphic units A, B, C, $\mathrm{D}, \mathrm{E}, \mathrm{F}, \mathrm{G}$, and $\mathrm{H}$. These units in the northern part of the Atlantic Coastal Plain range in age from Late Cretaceous to Early Cretaceous and Jurassic(?); they were defined, described, mapped, and illustrated by Brown, Miller, and Swain (1972). They were mapped throughout the subsurface in South Carolina and Georgia during this study, and their areal distribution, thickness, and wastereservoir potential are shown on the maps and stratigraphic sections in this report. Previously, Brown and Reid (1976) described and illustrated the waste-storage potential of Units $F, G$, and $H$ in the northern part of the Atlantic Coastal Plain.

With the selection of specific geologic units and establishment of a limiting value for the sodium chloride concentration in aquifer waters having waste-storage potential, our original definition of a sand-shale combination with reservoir potential can be amended so as to define a potential waste-storage reservoir "operational unit" for mapping purposes in the project area as follows:

A sand or sandstone layer, 20 feet or greater
in thickness, that is directly underlain and
overlain by a shale or clay layer, 20 feet or
greater in thickness, and which occurs in
Units A, B, C, D, E, F, G, or H, where each
of these units contains waters that have a
sodium chloride concentration greater than
$10,000 \mathrm{mg} / \mathrm{L}$.

Once defined, the extent and distribution of the wastestorage "operational unit" can be determined by mapping units A through $\mathrm{H}$ in the subsurface, by determining the relative position and thickness of their sand-shale layers, and by determining the concentration of sodium chloride in their contained waters. 
Using these procedures, the purposes of this report are to determine the presence or absence of the wastestorage operational unit in the project area and to list and evaluate some of the geohydrologic factors that control its incidence of occurrence and distribution.

\section{BASIC DATA AND DERIVATION OF MAPPABLE GEOLOGIC PARAMETERS}

Compilation and interpretation of the data for the several segments of the project were made jointly or separately by the authors.

Philip M. Brown planned the project, directed the work, correlated the sections, and wrote the report. Donald L. Brown calculated the salinities of formation waters from calibrated geophysical logs, determined the sand-shale geometry in key wells, and was chiefly responsible for preparation of the maps, some of which were modified from computer-drawn maps derived from basic project data. Marjorie S. Reid organized the basic well data, prepared the stratigraphic cross sections, the well-data tables, and other illustrative material. Orville B. Lloyd, Jr., assisted in the calculation of map values and preparation of the maps and was chiefly responsible for determining the accuracy of final map copy.

Subsurface data, derived from the study of well records, well cuttings and cores, and geophysical logs for about 400 wells, were examined during the course of the investigation. Eighty-eight wells were selected as having representative data of specific value for either regional mapping or waste-storage purposes. They make up the key-well network. Their location is shown in figure 1. Geohydrologic data for wells in the key-well network are listed on the well-data sheets in this report. On those sheets and throughout the report, the wells are identified in the manner described by Brown, Miller, and Swain (1972, p. 35-36). Because of space limitations, State and County names used in the well citations are abbreviated throughout the report. The abbreviations used for the counties in which key wells are located are as follows:

\begin{tabular}{|c|c|}
\hline \multicolumn{2}{|c|}{ Georgia } \\
\hline Ippling-.. & Dougher \\
\hline Atkinson -..... AT & Early \\
\hline Brantley - BRA & Echols-_-_-_- \\
\hline Brooks - & Glynn - \\
\hline Calhoun - & Houston--.-..-. \\
\hline Camden - CAM & Jeff Davis --.. \\
\hline Charlton------ & Laurens--- \\
\hline Chatham -........... & Liberty -........ \\
\hline Clinch--.---.--.-. & Lowndes-- \\
\hline Coffee--............ & Mitchell -- \\
\hline 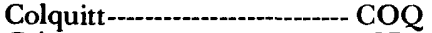 & Montgomery -............ \\
\hline Crisp - - & Pierce -.-.-- \\
\hline Decatur---------- & Pulaski - \\
\hline Dodge--.-...... & Screven --- \\
\hline 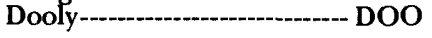 & Seminole - \\
\hline
\end{tabular}

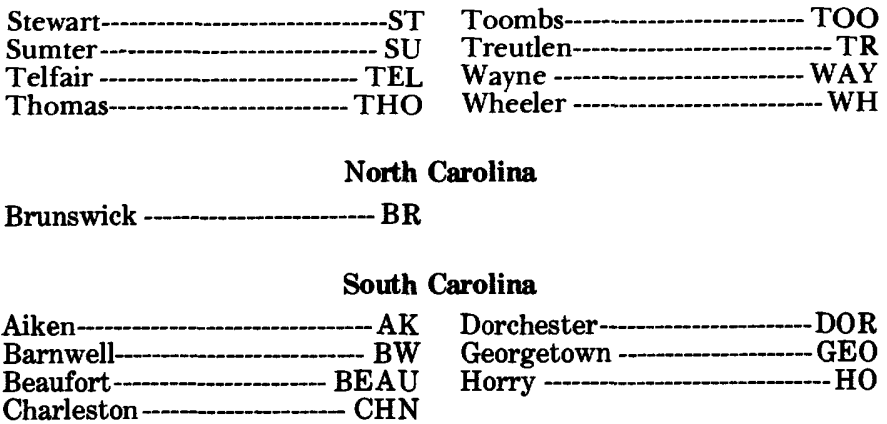

Using a combination of lithologic, paleontologic, and geophysical-log data, top and thickness values were established for the eight regional chronostratigraphic units (Units A through Unit $\mathrm{H}($ ?)) that occur in the wells which make up the key-well network. These values were then used to prepare eight stratigraphic cross sections as well as structure and isopach maps for each of the regional chronostratigraphic units and an isopach map combining the thickness of Units A through $\mathrm{E}$ and F through $\mathrm{H}($ ?). The structure and isopach maps were prepared using both mechanical and interpretive contouring methods. In many parts of South Carolina, where control was sparse, and lithic, paleontologic, or log markers were vague, it was necessary to invoke interval-correlation methods in some instances. In general, the overall correlation methods employed were judged to be sufficiently accurate for purposes of a regional waste-storage feasibility study.

Sand and shale lines were established on the SP (Self Potential) curve of electric logs. The thickness values for individual sand and shale layers were scaled off the logs and compared with thicknesses values and lithic characteristics shown on strip logs prepared from our examination of cuttings and cores from many of the wells in the key-well network. Sand-shale ratios were calculated from these thickness values. The sand and shale thickness values and the position of the sand and shale layers within the various chronostratigraphic units determined the presence or absence of the potential wastestorage "operational unit" in each well when used in conjunction with drill-stem test data and log-calculated sodium chloride values for formation water in individual geologic units. The log-calculated values for the approximate amount of sodium chloride present in formation waters in the deep subsurface were obtained using the SP and Resistivity methods described by Brown (1971). For most calculations, the SP rather than the Resistivity method was used because the latter method requires the use of porosity logs and they were available for only a few wells. Sodium chloride values obtained from both drill-stem tests and log calculation were used in determining the position of the isochlors drawn on the several maps in the report. Where calculated values for sodium chloride were available from more than one interval 
within a given geologic unit in any one well, the values were averaged and the resulting value was used in determining the position of the isochlors for a given geologic unit. (See supplementary-data section of report and table 8).

\section{GEOLOGIC UNITS AND THEIR SUBSURFACE DISTRIBUTION}

In the project area, eight geologic units were evaluated for waste-storage potential. They are designated informally by the letters $\mathrm{H}$ to $\mathrm{A}$. They range in age from Jurassic(?) to Late Cretaceous. Together, they make up one of the three determinant elements of the waste-storage "operational unit" as defined on page 3 . These letterdesignated geologic sequences were established and first mapped in the northern part of the Atlantic Coastal Plain, where a type-reference section in the subsurface was established for each sequence (Brown and others, 1972, pl. 3). The sequences comprise informal chronostratigraphic units of regional extent; each unit contains a lithology or lithologies judged to be of the same age.

During the present study, the lateral extension of most of these subsurface units into the southern part of the Atlantic Coastal Plain was based upon lithologic continuity, lithologic association, and faunal control, as interpreted from the study of well cuttings and cores and supplemented by interpretation of borehole geophysical logs. Correlation is judged to be consistent with the boundaries of depositional sequences that are extant in both the northern and southern segments of the Atlantic Coastal Plain. Correlation is consistent with, but not necessarily bounded by, elements of the faunal-control framework established for the northern part of the Atlantic Coastal Plain (Brown and others, 1972, p. 35, pl. 2), and the framework is extended to the south in the present study.

As mapped in the project area, Unit $\mathrm{G}(?)$ and Unit $\mathrm{H}(?)$ are considered to be questionably equivalent to Units $G$ and $\mathrm{H}$, respectively, as they are recognized in the northern part of the Atlantic Coastal Plain. Because these units occupy only a small area in southwestern Georgia and were not found to contain fossils, they could not be extended geographically from their type area into the project area on the basis of lithologic continuity and faunal control. Their presence in southwestern Georgia was established on the basis of electric-log correlation with well sections in southern Florida, first described by Applin and Applin (1965). The well sections in Florida have lithologic compositions and microfaunas similar to those occurring in Unit $\mathrm{G}$ and Unit $\mathrm{H}$ in North Carolina.

The eight letter-designated units mapped in the subsurface and their approximate relation to Provincial Series and Stages recognized in the Gulf Coast region (Mur- ray, 1961) are listed in table 1. As used in this report for purposes of discussion and cartographic presentation, Units $\mathrm{F}$ through $\mathrm{H}$ are considered Lower Cretaceous to Jurassic(?), and Units A through E, Upper Cretaceous. This is a natural grouping based on similarity of depositional sequences. The grouping is consistent with the usual and practical placement of the Upper CretaceousLower Cretaceous boundary so as to coincide with the Gulfian-Comanchean boundary in the Gulf and Atlantic Coast region (Murray, 1961, p. 331).

The subsurface distribution of the geologic units mapped is shown in this report on maps and stratigraphic cross sections (pl. 1).

Four principal regional structural features, all or parts of which are located in the project area, have affected the distribution, thickness, and lithology of the geologic units judged to have waste-storage potential. Previously known and described under various names, they are the Cape Fear Arch, the Savannah (Southeast Georgia) basin, the Central Georgia uplift, and the Apalachicola (Southwest Georgia) embayment (fig. 1). Among others, Murray (1961), Applin and Applin (1965, 1967), and Maher (1971) have discussed one or more of these structural features in some detail and described their influence in shaping the geometry of sediments that overlie them. In this report, their presence and their influence on geologic units judged to have waste-storage potential are indicated by structural contours on the top of the preUnit $H(?)$ basement surface and by structural top and thickness maps drawn for Units H(?) through A.

\section{ROCKS OF THE PRE-UNIT H(?) BASEMENT SURFACE}

As indicated on the cross sections and in well-data tables in this report, the geologic units judged to have waste-storage potential lie on a basement surface composed of a complex of different types of igneous, sedimentary, and metamorphic rocks that range in age from Precambrian(?) and early Paleozoic to Triassic(?).

Terrestrial red beds of probable Triassic age, interlayered with basalt and intruded by diabase, appear to have the most widespread distribution among those rocks that form the basement floor. They occur within and help to define a broad, northeast-trending rift belt that extends across central Georgia (section E-E', pl. 1) and into South Carolina. The maximum thickness of Triassic(?) rock penetrated in wells that make up the key-well network was 3,682 feet in a well (GA-PU-OT-1, section E-E', pl. 1) in Pulaski County, Ga.

Unmetamorphosed Paleozoic strata, consisting chiefly of quartzitic sandstone and black to maroon micaceous shale, have been described from a few wells in southern and western Georgia (see Applin and Applin, 1964 and 
TABLE 1.-Generalized correlation chart of upper Mesozoic units, Atlantic Coastal Plain, New York to Georgia

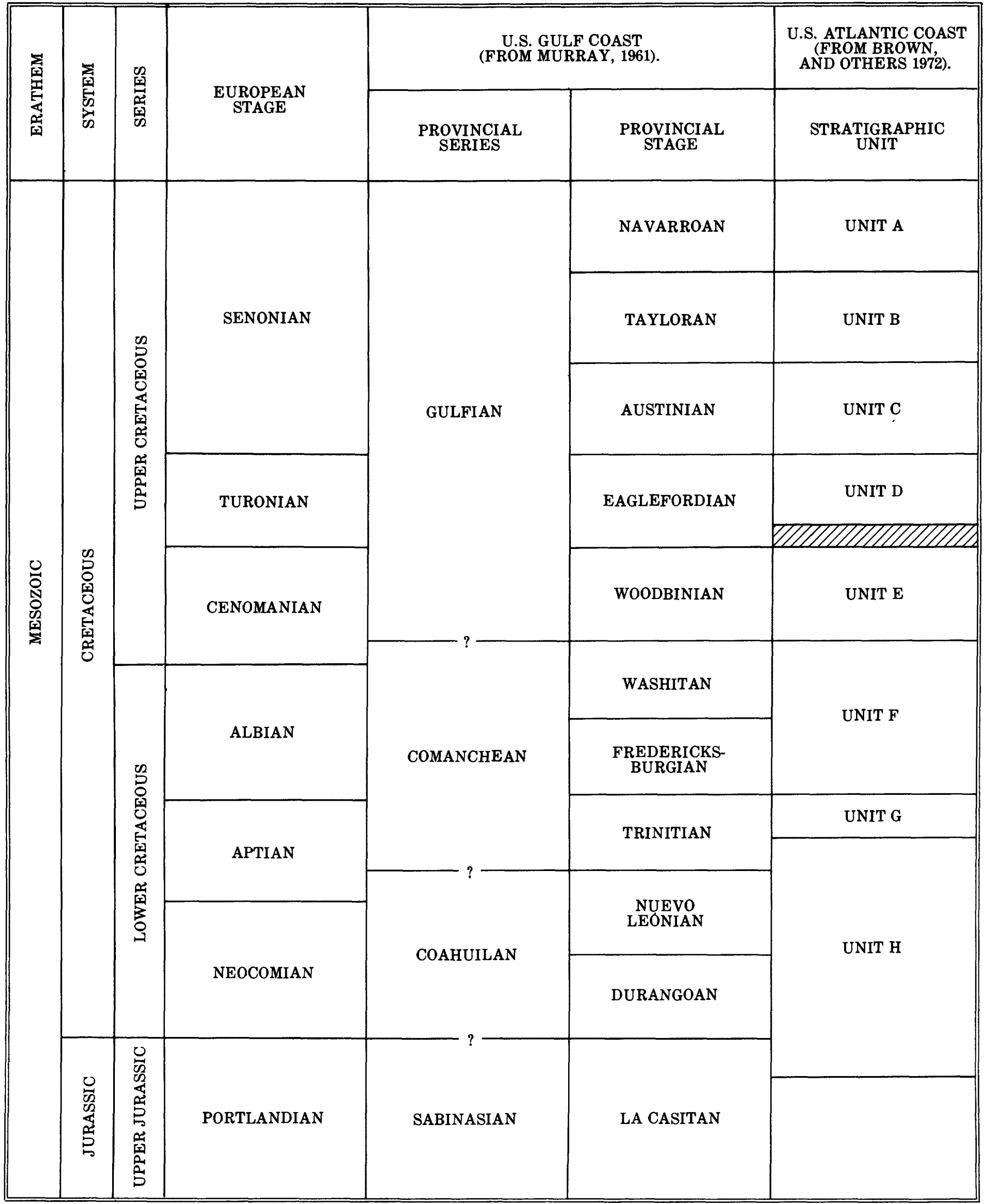




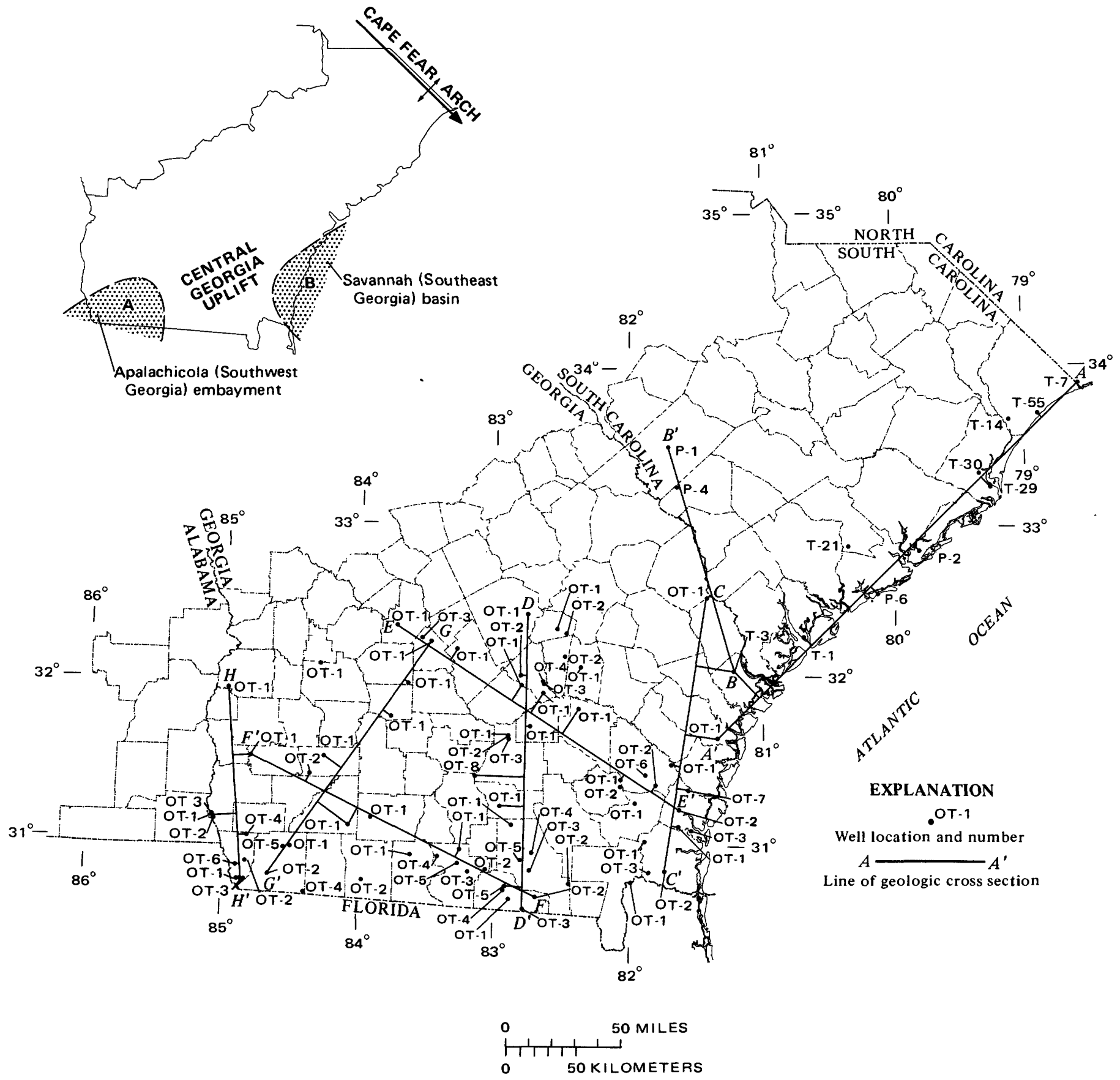

Figure 1-The location of principal structural features in the project area.

Marsalis, 1970). Wells that penetrate Paleozoic rock are located predominantly, but not exclusively, in Lowndes and Echols Counties, Ga. (section F-F', pl. 1). The maximum thickness of Paleozoic rock penetrated in wells that make up the key-well network was 3,080 feet in a well (GA-LOW-OT-1, section F-F', pl. 1) in Lowndes County, Ga.

Milton and Hurst (1965) provide a detailed description of some of the "basement" rocks encountered in wells in the Georgia Coastal Plain.
A map of the structural surface of pre-Unit $\mathrm{H}($ ?) basement rock is shown on plate $2 \mathrm{~A}$. The map shows that the basement descends rather evenly toward the southeast from the Cape Fear Arch to the vicinity of the Savannah (Southeast Georgia) basin wherein the maximum depth to the top of basement is greater than 4,600 feet below mean sea level in parts of Brantley, Camden and Glynn Counties, Ga. (See sections A-A' and C-C', pl. 1.) The two major depocenters in the project area, the Savannah (Southeast Georgia) basin and the Apalachicola (South- 
west Georgia) embayment, are separated by the saddleshaped area shown on the map, the Central Georgia uplift. In the project area the maximum depth to the top of basement, about 7,000 feet below mean sea level, occurs in southwestern Seminole County, Ga. (section $\mathrm{H}-\mathrm{H}$, pl. 1), located in the Apalachicola (Southwest Georgia) embayment.

The total thicknesses for Lower Cretaceous to Jurassic(?) rocks and for Upper Cretaceous rocks that overlie the pre-Unit $\mathrm{H}($ ?) basement and which were evaluated for their waste-storage potential are shown on plate $2 B$ and $2 \mathrm{C}$. Lower Cretaceous to Jurassic(?) rocks, that range from about 1,000 to 3,600 feet in thickness, occur chiefly within and peripheral to the Apalachicola (Southwest Georgia) embayment. Throughout most of the project area and except where a fault-bounded trough may be present locally, these rocks generally are less than 500 feet thick. From this thickness-distribution pattern, it can be inferred that most of the project area, including the Savannah (Southeast Georgia) basin, was positive relative to the actively subsiding Apalachicola (Southwest Georgia) embayment during Early Cretaceous to Jurassic(?) time.

As may be seen from comparison of plates $2 \mathrm{~B}$ and $2 \mathrm{C}$, the overall thickness-distribution pattern for the Upper Cretaceous rocks is significantly different than that shown for the Lower Cretaceous to Jurassic(?) rocks. In general the Upper Cretaceous rocks attain a maximum thickness of from 2,000-2,300 feet in a northeasterly to easterly trending zone across central Georgia from whence they thin toward both the northwest and the southeast. From the thickness-distribution pattern shown for Upper Cretaceous rocks, it can be inferred that the two major depocenters in the project area, the Savannah (Southeast Georgia) basin and the Apalachicola (Southwest Georgia) embayment, were not areas of major subsidence relative to adjacent geographic areas during Late Cretaceous time.

Assuming that waste-storage potential may be greatest where geologic units with such potential are the thickest, the Apalachicola (Southwest Georgia) embayment may have the greatest waste-storage potential insofar as its Lower Cretaceous to Jurassic(?) rocks are concerned. Similarly, the linear northeast-trending belt across central Georgia may have the greatest waste-storage potential insofar as its Upper Cretaceous rocks are concerned.

Information that pertains to the areal distribution of individual geologic units evaluated for waste-storage potential is combined with other data and shown on a series of maps (pls. 3 through 10). Maps prepared for each of the eight geologic units show the following:

1. The areal distribution of the unit in the subsurface.
2. Structural contours on the top of the unit: mean sea level datum.

3. Delineation of areas within the unit where the calculated sand-shale ratio is one or greater.

4. Delineation of areas where the unit contains nonusable ground water defined as having an approximate sodium chloride concentration of $10,000 \mathrm{mg} / \mathrm{L}$ or greater.

5. Contoured thickness of the unit in areas where it contains nonusable ground water.

6. Contoured values for the approximate sodium choride concentration of its nonusable ground water.

The information presented on the maps is described and interpreted in the section on "Waste-storage Potential of Geologic Units."

\section{SODIUM CHLORIDE CONCENTRATION OF FORMATION WATERS CONTAINED IN UNITS A THROUGH H(?)}

A major constraint imposed on the potential utilization of subsurface geologic units for waste-storage purposes is the amount of sodium chloride in their contained waters. In the project area, and by our definition of usable and nonusable ground waters (See p. 3), formation waters in the various geologic units present in the deep subsurface must contain sodium chloride in excess of $10,000 \mathrm{mg} / \mathrm{L}$ in order for these units to have waste-storage potential. This requirement effectively eliminates all the Cretaceous geologic units (Units A through F) mapped in the subsurface of South Carolina from consideration as potential waste-storage reservoirs. (Units G and $\mathrm{H}$, mapped elsewhere in the Atlantic Coastal Plain, are absent in South Carolina according to available well data.) During our investigation, no formation waters in geologic units of Gulfian and Comanchean age in the subsurface of South Carolina were found to contain as much as $10,000 \mathrm{mg} / \mathrm{L}$ of sodium chloride. Therefore, for purposes of our investigation of the waste-storage potential of some Mesozoic units in the southern part of the Atlantic Coastal Plain and irrespective of their sand-shale geometry, South Carolina is judged to have no wastestorage potential insofar as Units A through $\mathrm{H}($ ?) are concerned. In the following segments of this report there is no additional discussion of waste-storage potential in South Carolina.

In Georgia, all (Units $\mathrm{G}($ ?) and $\mathrm{H}($ ?)) or parts (Units A through F) of the eight chronostratigraphic units mapped in the subsurface contain formation waters that have a sodium chloride concentration in excess of $10,000 \mathrm{mg} / \mathrm{L}$. The areal distribution of this type of formation water for each of the eight geologic units is shown by value-designated isochlors $(10,000 \mathrm{mg} / \mathrm{L}$ and 
greater) on the structure and isopach maps drawn for individual units. In general and as shown on the individual structure maps, the boundary between those parts of each geologic unit that do and do not have waste-storage potential, insofar as the sodium chloride concentration of formation waters is a determinant, appears to be chiefly controlled by structural configuration as might be expected.

In table 2 a numerical value, determined by planimeter measurement, is given for the square mile area where each geologic unit contains formation waters having a sodium chloride concentration in excess of $10,000 \mathrm{mg} /$ $\mathrm{L}$; these are the areas that have waste-storage potential. Comparison of these values indicates that Unit F has the greatest and Unit $\mathrm{H}($ ?) the least waste-storage potential in terms of areal extent without considering the sandshale geometry of each unit or its thickness.

From inspection of the structure maps on which the isochlors are superimposed, the geologic units being evaluated for waste-storage purposes in Georgia appear, in general, to have the greatest overall waste-storage potential in those areas where they lie at least 2,000 feet below mean sea level. In table 2 , a numerical value, determined by planimeter measurement, is given for the square mile area in which each unit lies at a depth greater than 2,000 feet below mean sea level. A percentage value is given for that part of the geologic unit, deeper than 2,000 feet below mean sea level, which contains formation water with a sodium chloride concentration greater than $10,000 \mathrm{mg} / \mathrm{L}$. Comparison of the percentage values indicates that, where segments of each geologic unit lie deeper than 2,000 feet below mean sea level, Unit G(?) and Unit H(?) have the greatest and Unit $\mathrm{D}$ the least waste-storage potential in terms of a depth/ formation-water relation only.

For evaluation and planning purposes and from the depth and calculated salinity data contoured on the structure maps, a similar correspondence may be established for a depth/formation-water relation at different depths

TABLE 2.-Comparative salinity/depth data for Units A through $H($ ?) in Georgia

\begin{tabular}{|c|c|c|c|}
\hline Geologic Unit ${ }^{c}$ & $\begin{array}{c}\text { Area where unit } \\
\text { contains water having } \\
\text { a sodium chloride } \\
\text { concentration greater } \\
\text { than } 10,000 \mathrm{mg} / \mathrm{L} \\
\text { (sq mi) }\end{array}$ & $\begin{array}{c}\text { Area where unit lies } \\
\text { deeper than } 2,000 \\
\text { feet below mean sea } \\
\text { level (sq mi) }\end{array}$ & $\begin{array}{l}\text { Percent of square } \\
\text { mile area where unit } \\
\text { is deeper than } 2,000 \\
\text { feet and contains } \\
\text { water having a } \\
\text { sodium chloride } \\
\text { concentration greater } \\
\text { than } 10,000 \mathrm{mg} / \mathrm{L}\end{array}$ \\
\hline $\begin{array}{l}\mathrm{A}- \\
\mathrm{B}- \\
\mathrm{C}- \\
\mathrm{D} \\
\mathrm{E} \\
\mathrm{F}- \\
\mathrm{G}(?) \\
\mathrm{H}(?)\end{array}$ & $\begin{array}{r}5,824 \\
7,232 \\
8,876 \\
7,240 \\
13,653 \\
16,319 \\
6,236 \\
4,608\end{array}$ & \begin{tabular}{r|}
9,361 \\
12,697 \\
18,433 \\
22,533 \\
25,348 \\
28,109 \\
6,236 \\
4,608
\end{tabular} & $\begin{array}{r}62 \\
57 \\
48 \\
32 \\
54 \\
58 \\
100 \\
100\end{array}$ \\
\hline
\end{tabular}

of burial for given geologic units. If detailed waste-storage studies are undertaken in the project area, it may be convenient to establish such correspondence for specific cases of waste-storage evaluation where depth of burial may constitute a critical risk or economic factor in an overall evaluation of the waste-storage potential of several geologic units which otherwise may have about equal potential.

Beyond providing information that can be used to position a mappable boundary between usable and nonusable formation waters in geologic units judged to have waste-storage potential, the basic information, that pertains to the lateral extent of differentially saline types of both usable and nonusable ground waters, can be used for other purposes. It can be used to indicate the distribution and extent of natural gravity-flow or "flushing" patterns that are characteristic of the geologic units. It can be used to plan the development of or to manage the ground water contained in these geologic units. Also, it can be used for policy-making purposes if local governmental agencies feel the need to establish a more-limiting or less-limiting salinity criterion than the one used in this report for separating usable from nonusable ground waters.

According to our definition of usable and nonusable ground water, Units A through $\mathrm{F}$ contain both types of water. Units $G(?)$ and $H(?)$ contain only nonusable ground water. For comparative purposes isochlor maps for Units A through $\mathrm{H}($ ?) are shown on plate 11. The areal distribution of ground waters that contain sodium chloride in excess of $1,000 \mathrm{mg} / \mathrm{L}$ is shown by isochlors for Units A through F. Similarly, isochlors greater than $25,000 \mathrm{mg} / \mathrm{L}$ are shown for Unit $\mathrm{G}(?)$ and greater than $50,000 \mathrm{mg} / \mathrm{L}$ for Unit $\mathrm{H}(?)$.

From inspection of the maps shown on plate 11, it is apparent that gravity-flow or "flushing" patterns now characteristic of Units A through $F$ have a definite northsouth alinement, and for Units G(?) and H(?) a northeastsouthwest alinement. The maximum concentration of sodium chloride recognized in ground waters in Georgia occurs in Unit F in parts of Brooks and Lowndes Counties; the concentration there is judged to exceed $200,000 \mathrm{mg} / \mathrm{L}$.

\section{SAND-SHALE GEOMETRY}

There are three determinant factors embodied in our definition of a waste-storage "operational unit" for the project area. They are: (1) the distribution of Units A through $\mathrm{H}($ ?) in the subsurface, (2) the distribution of nonusable ground water within each unit, (3) the presence within each unit of sand or sandstone layers, 20 feet or greater in thickness, that are directly overlain and underlain by shale or clay layers, 20 feet or greater in thickness. 
Once spatial distributions for the first two factors have been determined, final determination as to whether or not potential waste-storage reservoirs are present depends entirely on the presence or absence of the sandshale (reservoir, reservoir-seal) combination in individual boreholes that penetrate given geologic units where they contain nonusable ground water. The determination as to the presence or absence of the requisite sand-shale combination is made from geophysical or lithologic-log evaluation of the stratigraphic column present in each available well. The evaluation is made in terms of the number of occurrences and thicknesses of sand, shale, and carbonate components, together with their relative positioning for each of the eight geologic units that might be present in a given borehole. From respective thickness values for the three lithologic components scaled off the logs, and from their geometric arrangement in a stratigraphic column, a judgment is made as to whether the sand-shale combination, required by the definition of the waste-storage "operational unit," is present or absent.

Using the procedures as outlined herein, it was determined that the requisite sand-shale (reservoir, reservoirseal) combination is present one or more times in 15 wells, wherein the geologic units (A through $\mathrm{H}($ ?)) contain nonusable ground waters. Therefore, 17 percent of the 88 wells that make up the key-well network were found to penetrate geologic units judged to have some degree of waste-storage potential. Wells that have this storage potential, together with notation as to the geologic units and number of reservoir sands in each unit that have such potential, are listed in table 3 .

From inspection of the table, it is apparent that Unit $\mathrm{F}$ has the greatest and Unit $\mathrm{C}$ the least waste-storage potential in a regional sense. A combined total of 20 po-

TABLE 3.-Number of reservoir sands and wells with waste-storage potential in Units A through H(?) in Georgia

\begin{tabular}{|c|c|c|c|c|c|c|c|c|}
\hline \multirow{3}{*}{ Wells } & \multicolumn{8}{|c|}{ Geologic Units } \\
\hline & A & B & $\mathbf{C}$ & D & $\mathbf{E}$ & $\mathbf{F}$ & $\mathbf{G}(?)$ & $\mathrm{H}(?)$ \\
\hline & \multicolumn{8}{|c|}{ Number of sands with reservoir potential } \\
\hline 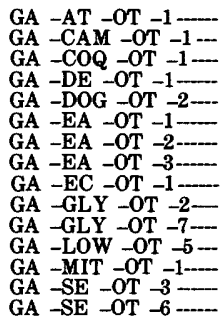 & $\begin{array}{l}\overline{-} \\
\overline{-} \\
\overline{-} \\
\overline{-} \\
\overline{-} \\
\overline{-} \\
\overline{-} \\
\overline{1} \\
\overline{-} \\
\overline{-} \\
\overline{-} \\
\overline{-}\end{array}$ & $\begin{array}{l}\overline{1} \\
\overline{-} \\
\overline{-} \\
\overline{-} \\
\overline{-} \\
\overline{-} \\
\overline{-} \\
\overline{-} \\
\overline{-} \\
\overline{-} \\
\overline{-}\end{array}$ & 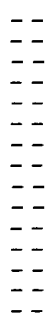 & 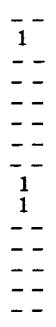 & $\begin{array}{l}\overline{--} \\
\overline{1} \\
-- \\
\overline{1} \\
\overline{-} \\
\overline{-} \\
\overline{-} \\
\overline{-} \\
\overline{-} \\
\overline{-} \\
\overline{-}\end{array}$ & $\begin{array}{l}1 \\
-- \\
\overline{1}- \\
1 \\
1 \\
2 \\
1 \\
-- \\
\overline{-}- \\
1 \\
\overline{1}- \\
2\end{array}$ & $\begin{array}{l}=- \\
=- \\
=- \\
1 \\
=- \\
=- \\
=- \\
=- \\
=- \\
= \\
= \\
=\end{array}$ & $\begin{array}{l}-\overline{-} \\
\overline{-} \\
\overline{-} \\
\overline{-} \\
\overline{-} \\
\overline{-} \\
\overline{-} \\
\overline{-} \\
\overline{1} \\
\overline{-} \\
-\overline{-}\end{array}$ \\
\hline $\begin{array}{l}\text { Total sands with } \\
\text { reservoir } \\
\text { potential--.- } \\
\text { Total wells in } \\
\text { unit with waste- } \\
\text { storage potential }\end{array}$ & 1 & 1 & $\mathbf{0}$ & 3 & 2 & 11 & 1 & 1 \\
\hline
\end{tabular}

tential-reservoir sands are present in 15 wells. Five wells contain two potential-reservoir sands. Ten wells contain one such sand. The 15 wells, judged to have waste-storage potential, are located in 10 different counties. Early County, Ga., contains the greatest number of such wells (3) located in any one county.

Data sheets for wells judged to have waste-storage potential are located in the supplementary data section of the report. Brown and Reid $(1976$, p. 5) previously described the nature of the data and the manner in which they are used as follows:

The entries on the data sheets consist of 20 categories of data that relate either to the depth of occurrence or thickness of geologic units, to the depth of occurrence or thickness of a unit's sand and shale components, or to useful combinations of these data. The 20 categories of data were used directly or were combined or averaged so as to derive quantitative geologic parameters that could be mapped or tabulated to show the occurrence and distribution of potential waste-storage reservoirs in the study area.

For purposes of comparative evaluation of the wastestorage potential of the geologic units mapped, in terms of quantitative elements of their sand-shale geometries, the values listed for 10 categories of data shown on the individual well-data sheets were averaged if a unit contained more than one potential waste-storage interval or was listed individually if only one interval was present in a given unit. The individual or averaged values are listed in table 4 . Values such as these, when considered within a cost-risk-benefit framework, can provide a quantitative basis for assessing the relative waste-storage potential of the different geologic units in the project area. Also, when compared with similar data from outside the project area, such as in the northern part of the Atlantic Coastal Plain (Brown and Reid, 1976, table 2, p. 15), they provide a quantitative basis for a regional assessment of relative waste-storage potential within some of the same geologic units.

If sands are considered to represent permeable zones and shales relatively impermeable zones in the geologic units judged to have waste-storage potential, then the ratio of a unit's sand thickness to its shale thickness indirectly denotes the relation between permeability and permeability-barrier potential in clastic sections considered for waste storage (Brown and Reid, 1976, p. 7). For sections composed of equal thicknesses of sand and shale, the ratio value is one and the total thickness of permeability and permeability-barrier zones in sections considered for waste storage is equal. As the ratio value increases from 1 to infinity, the greater becomes the proportionate thickness of potential permeability zones in the section. Conversely, as the ratio value decreases from 1 to 0 the greater becomes the proportionate thickness of potential permeability-barrier zones in the section. 
TABLE 4. Summary of selected data for waste-storage parameters, Units A through H(?) in Georgia

[Unit C contains no potential waste-storage intervals. Units A, B, G(?), and $H(?)$ each contain one potential waste-storage interval. Units $\mathrm{D}, \mathrm{E}$, and $\mathrm{F}$ each contains more than one potential waste-storage interval]

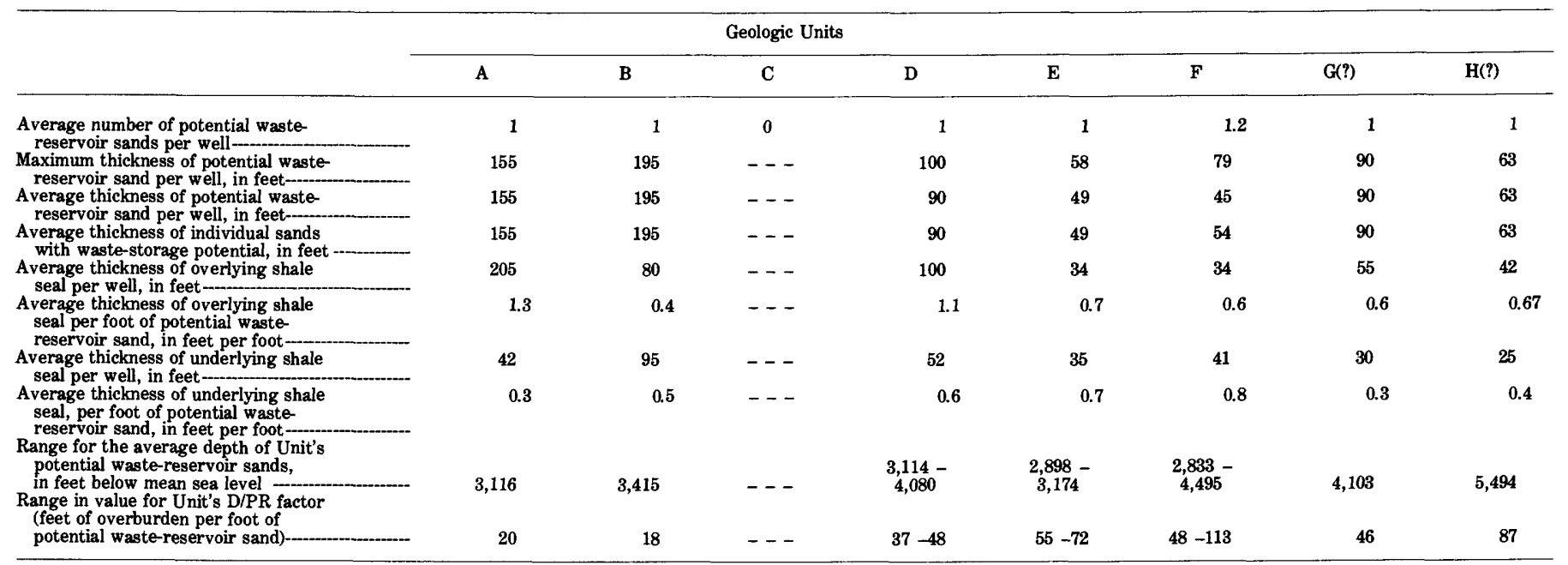

TABLE 5.-Summary distribution of sand-shale ratio values for Units A through H(?) in Georgia

[Formation waters contain concentrations of sodium chloride greater than $10,000 \mathrm{mg} / \mathrm{L}$ ]

\begin{tabular}{|c|c|c|c|c|c|c|c|c|c|c|c|c|}
\hline \multirow{3}{*}{$\begin{array}{c}\text { Geologic } \\
\text { unit }\end{array}$} & \multicolumn{5}{|c|}{ 1. Sand-shale ratio is 1 or greater } & \multicolumn{5}{|c|}{ 2. Sand-shale ratio is less than 1} & \multicolumn{2}{|c|}{$\begin{array}{l}\text { 3. Total of columns } \\
1 \text { and } 2\end{array}$} \\
\hline & \multicolumn{2}{|c|}{ Area } & \multirow{2}{*}{$\begin{array}{l}\text { Average } \\
\text { thickness } \\
\text { (ft) }\end{array}$} & \multicolumn{2}{|c|}{ Volume } & \multicolumn{2}{|c|}{ Area } & \multirow{2}{*}{$\begin{array}{c}\text { Average } \\
\text { thickness } \\
\text { (ft) }\end{array}$} & \multicolumn{2}{|c|}{ Volume } & \multirow{2}{*}{$\begin{array}{c}\text { Area } \\
\begin{array}{c}\text { Square } \\
\text { miles }\end{array}\end{array}$} & \multirow{2}{*}{$\begin{array}{c}\text { Volume } \\
\text { Cubic } \\
\text { miles }\end{array}$} \\
\hline & $\begin{array}{c}\text { Square } \\
\text { miles }\end{array}$ & $\begin{array}{l}\text { Percent } \\
\text { of total }\end{array}$ & & $\begin{array}{l}\text { Cubic } \\
\text { miles }\end{array}$ & $\begin{array}{l}\text { Percent } \\
\text { of total }\end{array}$ & $\begin{array}{l}\text { Square } \\
\text { miles }\end{array}$ & $\begin{array}{l}\text { Percent } \\
\text { of total }\end{array}$ & & $\begin{array}{l}\text { Cubic } \\
\text { miles }\end{array}$ & $\begin{array}{l}\text { Percent } \\
\text { of total }\end{array}$ & & \\
\hline $\begin{array}{l}\mathrm{A}- \\
\mathrm{B}- \\
\mathrm{C} \\
\mathrm{D}- \\
\mathrm{E}- \\
\mathrm{F}- \\
\mathrm{G}(?)-\mathrm{-}-\mathrm{-} \\
\mathrm{H}(?)-\mathrm{-}\end{array}$ & $\begin{array}{r}1,145 \\
1,851 \\
0 \\
2,172 \\
221 \\
8,975 \\
62 \\
0\end{array}$ & $\begin{array}{r}20 \\
26 \\
0 \\
30 \\
2 \\
55 \\
1 \\
0\end{array}$ & $\begin{array}{r}141 \\
260 \\
327 \\
123 \\
774 \\
1,070 \\
\end{array}$ & $\begin{array}{c}30.6 \\
91.1 \\
134 \\
5.1 \\
1,316 \\
12.6 \\
-\end{array}$ & $\begin{array}{r}9 \\
22 \\
28 \\
1 \\
63 \\
1 \\
\end{array}$ & \begin{tabular}{|r|}
, 679 \\
5,381 \\
8,876 \\
5,068 \\
13,432 \\
7,344 \\
6,174 \\
4,608
\end{tabular} & $\begin{array}{r}80 \\
74 \\
100 \\
70 \\
98 \\
45 \\
99 \\
100\end{array}$ & $\begin{array}{l}359 \\
314 \\
380 \\
353 \\
172 \\
549 \\
754 \\
655\end{array}$ & $\begin{array}{l}318 \\
320 \\
639 \\
339 \\
438 \\
764 \\
882 \\
572\end{array}$ & $\begin{array}{r}91 \\
78 \\
100 \\
72 \\
99 \\
37 \\
99 \\
100\end{array}$ & $\begin{array}{r}5,824 \\
7,232 \\
8,876 \\
7,240 \\
13,653 \\
16,319 \\
6,236 \\
4,608\end{array}$ & $\begin{array}{r}\mathbf{3 4 9} \\
\mathbf{4 1 1} \\
639 \\
473 \\
\mathbf{4 4 3} \\
\mathbf{2 , 0 8 0} \\
\mathbf{8 9 5} \\
\mathbf{5 7 2}\end{array}$ \\
\hline
\end{tabular}

Sand-shale ratios were calculated for sections cut in wells that make up the key-well network. The ratio values are plotted on sand-shale distribution maps prepared for individual geologic units. Areas where the sand-shale ratio is one or greater are delineated by a map pattern. These are areas where the thickness of potential permeability zones is equal to, or greater than, the thickness of potential permeability-barrier zones. Conversely, nonpatterned areas on these maps are areas where the thickness of potential permeability-barrier zones is greater than the thickness of potential permeability zones.

For each geologic unit, areas and volumes were computed for the patterned and nonpatterned ratio-value zones shown on the individual sand-shale distribution maps. These data are listed in table 5 . They provide a quantitative basis for evaluating the proportionate permeability and permeability-barrier distribution present in the sediment mass where it is judged to have waste-storage potential.

\section{WASTE-STORAGE POTENTIAL OF GEOLOGIC UNITS}

\section{UNIT H(?), ROCKS OF CRETACEOUS AND LATE JURASSIC(?) AGE}

The designated type-reference section for Unit $\mathrm{H}$ (Brown and others, 1972, p. 38, pl. 50) is a well section, 1,120 feet thick, in Pamlico Sound, Hyde County, N.C.

In the project area, Unit $\mathrm{H}(?)$ is confined to the subsurface. Its occurrence is restricted to a small block of counties in southwestern Georgia (pl. 3A) which lie within and help to define the Apalachicola (Southwest Georgia) embayment (fig. 1). Unit $\mathrm{H}($ ?) is judged to be present in 9 of the 88 wells that make up the key-well network (pl. 3C and table 6). Throughout its extent, Unit $\mathrm{H}($ ?) contains nonusable ground water ( $\mathrm{pl} .3 \mathrm{C}$ ). On the basis of the geometry of its combined sand-shale layers, Unit $\mathrm{H}(?)$ is judged to have waste-storage potential in only one of the nine wells in which it is present (pl. 3C). 
The sediments of Unit H(?) consist of varicolored (maroon, purple, green, and yellow) micaceous sandy clay, medium- to coarse-grained clayey sand and sandstone, and, occasionally, lenses of poorly sorted quartzitic and feldspathic gravel, that may contain diabase pebbles. Applin and Applin (1964) provide detailed lithologic descriptions for sediments in Georgia that we include in Unit $\mathrm{H}(?)$ in this report.

Representative geophysical-log sections and depth of occurrence and thickness-distribution patterns for Unit $\mathrm{H}($ ?) are shown on the stratigraphic cross sections (pl. 1, sections F-F', G-G', and $\left.\mathrm{H}-\mathrm{H}^{\prime}\right)$. The depth to the top of the unit ranges from about 4,200 feet below mean sea level, in parts of Lee, Randolf, Terrell, and Worth Counties, Ga., to about 5,800 feet below mean sea level in parts of Decatur and Seminole Counties, Ga. (pl. 3A). The thickness of Unit $\mathrm{H}($ ?) ranges from less than 100 feet in parts of Lee and Worth Counties, Ga. to more than 1,100 feet in parts of Decatur and Seminole Counties, Ga. (pl. 3B). As shown by contours (pl. 3B), the approximate sodium chloride concentration of ground water in Unit $\mathrm{H}($ ?) ranges from greater than $10,000 \mathrm{mg} /$ $\mathrm{L}$ to greater than $100,000 \mathrm{mg} / \mathrm{L}$. As calculated from structure-contour and isopach maps (pl. 3A and $3 \mathrm{~B}$ ) for areas which contain nonusable ground water (pl. 3B), Unit $H($ ?) covers an area of 4,608 square miles and contains a volume of sediments comprising 572 cubic miles. (See table 5.)

In areas where Unit $\mathrm{H}(?)$ contains nonusable ground water (pl. 3C) and may, therefore, have waste-storage potential, the requisite sand-shale (reservoir, reservoirseal) combination, as defined on page 3 , was present in only one well (GA-MIT-OT-1) in Mitchell County, Ga. (pl. 3C). In this well, the depth to the top of Unit $\mathrm{H}($ ?) is 5,302 feet below mean sea level and the unit is 575 feet thick. The total thickness comprises 75 feet (13 percent) sand and 500 feet ( 87 percent) shale.

One sand layer, 63 feet thick, immediately overlain by a shale layer 42 feet thick and underlain by a shale layer 25 feet thick, was judged to have waste-storage potential, in terms of the criteria for such established in this report. In this well, the depth to the top of the potential waste-reservoir sand is 5,494 feet below mean sea level. The D/PR factor (average depth of potential reservoir sand occurrence/total thickness of Unit's potential reservoir sand) is 87 . The D/PR factor, or depth/potential reservoir factor, shows the comparative thickness of overburden per foot of potential reservoir sand in areas where potential waste-storage reservoirs are present (Brown and Reid, 1976, p. 6). The factor is useful in making a comparative assessment of regional waste-storage potential within a cost-risk-benefit framework.

Geohydrologic data for the one well section in Unit $\mathrm{H}($ ?), judged to have waste-storage potential, are listed in the supplementary-data section of this report. A comparative summary of the data from this and other wells that have sections with waste-storage potential and which penetrate one or more of the geologic units evaluated for waste-storage purposes is listed in table 4.

In general, the absence of waste-storage potential within Unit $\mathrm{H}($ ?) may be attributed to the fact that the sections penetrated are sand-deficient rather than shaledeficient.

\section{UNIT G(?), ROCKS OF CRETACEOUS AGE}

The designated type-reference section for Unit $G$ (Brown and others, 1972, p. 39, pl. 50) is a well section, 942 feet thick, in Carteret County, N.C.

Unit G(?) is confined to the subsurface in the project area. Like Unit $\mathrm{H}($ ?), its occurrence is restricted to a small block of counties in southwestern Georgia (pl. 4A); these counties lie within the Apalachicola (Southwest Georgia) embayment (fig. 1). Unit G(?) is judged to be present in 14 of the 88 wells that make up the key-well network (pl. 4C and table 6). Throughout its extent, Unit $\mathrm{G}(?)$ contains nonusable ground water (pl. 4C). On the basis of the geometry of its combined sand-shale layers, Unit G(?) is judged to have waste-storage potential in only 1 of 14 wells in which it is present.

The sediments of Unit G(?) chiefly consist of mottled, red and brown to tan micaceous shale, fine- to coarsegrained, angular to subrounded quartz sand and sandstone, that may contain red nodular limestone and gray to green nodules of chert. Applin and Applin (1964) provide detailed lithologic descriptions for sediments in Georgia that we include in Unit G(?) in this report.

Representative geophysical-log sections and depth-ofoccurrence and thickness-distribution patterns for Unit $\mathrm{G}(?)$ are shown on the stratigraphic cross sections (pl. 1, sections F-F', G-G', and H-H'). The depth to the top of the unit ranges from about 3,200 feet below mean sea level, in parts of Crisp County, Ga., to about 5,000 feet below mean sea level in parts of Decatur and Grady Counties, Ga. (pl. 4A). The thickness of Unit G(?) ranges from less than 500 feet, in parts of Crisp and Turner Counties, Ga., to more than 1,000 feet in parts of Baker, Miller, Mitchell, and Seminole Counties, Ga. (pl. 4B). As shown by contours (pl. 4B), the approximate sodium chloride concentration of ground waters in Unit G(?) ranges from greater than $10,000 \mathrm{mg} / \mathrm{L}$ to greater than $100,000 \mathrm{mg} / \mathrm{L}$. As calculated from structure-contour and isopach maps (pl. 4A and 4B) for areas where it contains nonusable ground water (pl. 4B), Unit G(?) extends across an area of 6,326 square miles and contains a volume of sediments equivalent to 895 cubic miles. (See table 5.)

In areas where Unit $G(?)$ contains nonusable ground water (pl. 4C) and may, therefore, have potential for 
waste storage, the requisite sand-shale (reservoir, reservoir-seal) combination, as defined on page 3, was present in only one well (GA-DOG-OT-2) in Dougherty County, $\mathrm{Ga}$ (pl. $4 \mathrm{C}$ ). In this well the depth to the top of Unit $G(?)$ is 4,013 feet below mean sea level and the unit is 740 feet thick. The total thickness comprises 170 feet (23 percent) sand and 570 feet (77 percent) shale.

One sand layer, 90 feet thick, immediately overlain by a shale layer 55 feet thick and underlain by a shale layer 30 feet thick, was judged to have waste-storage potential, in terms of the criteria established in this report. In this well the depth to the top of the potential waste-reservoir sand is 4,103 feet below mean sea level. The $D /$ PR factor (average depth of potential reservoir sand occurrence/total thickness of Unit's potential reservoir sand) is 46.

Geohydrologic data for the one well section in Unit $\mathrm{G}($ ?) judged to have waste-storage potential are listed in the supplementary-data section of this report. A comparative summary of the data from this and other wells that have sections with waste-storage potential and which penetrate one or more of the geologic units evaluated for waste-storage purposes is listed in table 4.

\section{UNIT F, ROCKS OF CRETACEOUS AGE}

The designated type-reference section for Unit $F$ (Brown and others, 1972, p. 40, pl. 43) is a well section, 83 feet thick, in Halifax County, N.C.

In the project area, Unit $F$ has a wide distribution that extends from the North Carolina-South Carolina border, southwestward, to the Georgia-Alabama border (pl. 5A). It ranges in thickness from less than 100 feet, over much of the South Carolina and eastern Georgia coastal plains, to more than 1,500 feet, in parts of Early, Miller, and Seminole Counties in southwestern Georgia. The maximum thickness measured, 1,560 feet, is in a well in Early County, Ga. (GA-EA-OT-1, table 6).

Unit $\mathrm{F}$ is present in 81 of the 88 wells that comprise the key-well network (pl. 5A). Unit F contains both usable and nonusable ground water whose distribution is shown on plate 5 and plate 12 . In areas where Unit $F$ contains nonusable ground water, it is judged to be present in 52 of the 88 wells that make-up the key-well network. In 9 of these 52 wells, Unit F is judged to have waste-storage potential on the basis of the geometry of its combined sand-shale layers (pl. 5C).

The sediments of Unit F chiefly consist of gray, brown, and $\tan$ micaceous shale interlayered with poorly sorted, fine- to coarse-grained sandstone or loosely consolidated sand. Rosettes, nodules, and balls of siderite commonly occur in the sediments. Glauconite is present locally in trace amounts. Herrick (1961) and Applin and Applin (1964) provide detailed lithologic descriptions for sediments in Georgia that we include in Unit F in this report.
Representative geophysical-log sections and depth-ofoccurrence and thickness-distribution patterns for Unit $F$ are shown on the eight stratigraphic cross sections assembled on plate 1 . In areas where Unit $F$ contains nonusable ground water, the depth to the top of the unit ranges from about 1,700 feet below mean sea level, in parts of Dooly County, Ga., to about 3,600 feet below mean sea level, in parts of Brooks, Decatur, Grady, and Thomas Counties, Ga. (pl. 5A). Also in areas of nonusable ground water, the thickness of Unit $F$ ranges from less than 100 feet, in parts of eastern Georgia, to more than 1,500 feet, in parts of southwestern Georgia (pl. 5B). As shown by contours (pl. 5B), the approximate sodium chloride concentration of nonusable ground water in Unit $F$ ranges from greater than $10,000 \mathrm{mg} / \mathrm{L}$ to greater than $200,000 \mathrm{mg} / \mathrm{L}$. As calculated from structure-contour and isopach maps (pl. 5A and 5B) for areas where it contains nonusable ground water (pl. 5B), Unit $F$ covers an area of 16,319 square miles and contains a volume of sediments equivalent to 2,080 cubic miles. (See table 5.)

In areas where Unit $F$ contains nonusable ground water (pl. 5C) and may, therefore, have waste-storage potential, the requisite sand-shale (reservoir, reservoirseal) combination, as defined on page 3 , was present in nine wells located in six counties in Georgia (pl. 5C) as follows:

$$
\begin{aligned}
& \text { GA-AT-OT-1 } \\
& \text { GA-DE-OT-1 } \\
& \text { GA-DOG-OT-2 } \\
& \text { GA-EA-OT-1 } \\
& \text { GA-EA-OT-2 } \\
& \text { GA-EA-OT-3 } \\
& \text { GA-LOW-OT-5 } \\
& \text { GA-SE-OT-3 } \\
& \text { GA-SE-OT-6 }
\end{aligned}
$$

In two of the nine wells (GA-EA-OT-2 and GA-SE-OT-6), the sand-shale combination with wastestorage potential occurs twice. In the other seven wells, the combination occurs once. In the nine wells the depth to the top of Unit $F$ ranges from 2,803 feet (GA-D0G-OT-2) to 3,777 feet (GA-AT-OT-1) below mean sea level and averages 3,220 feet. In these wells the total thickness of Unit $F$ ranges from 222 feet (GA-AT-OT-1) to 1,560 feet (GA-EA-OT-1) and averages 1,225 feet.

Total sand thickness for Unit $F$ in the nine wells ranges from 108 feet (GA-AT-0T-1) to 1,228 feet (GA-EA-OT-2) and averages 805 feet. Total shale thickness for Unit $F$ in the nine wells ranges from 114 feet (GA-AT-OT-1) to 767 feet (GA-EA-OT-3) and averages 420 feet.

The thickness of Unit F's potential reservoir sands ranges from 35 feet (GA-LOW-OT-5) to 79 feet 
(GA-EA-OT-2) and averages 54 feet in the nine wells. The thickness of the individual sands range from 25 to 62 feet and averages 44 feet. The thickness of Unit F's potential reservoir seals, that immediately overlie reservoir sands, range from 20 feet (GA-AT-OT-1, GA-EA-OT-3, GA-SE-OT-3, and GA-SE-OT-6) to 40 feet (GA-DE-OT-1) and averages 34 feet. The range in thickness is the same for the individual overlying seals, but the individual average thickness is 28 feet. Similarly, the thickness of underlying reservoir seals ranges from 22 feet (GA-SE-OT-6) to 60 feet (GA-DE-OT-1) and averages 41 feet. Here also the range in thickness of the individual underlying seals is the same but the average thickness is 34 feet.

In wells where Unit $F$ has waste-storage potential, the depth to the top of the potential reservoir sand ranges from 2,833 feet (GA-DOG-OT-2) to 4,495 feet (GA-SE-OT-3) below mean sea level and averages 3,843 feet. For the same wells the DP/R factor (average depth of the individual potential reservoir sand occurrence/total thickness of Unit's potential reservoir sand) ranges from 64 (GA-EA-OT-3) to 154 (GA-EA-OT-2) and averages 94. Lines of equal value for the D/PR factor calculated for Unit $\mathrm{F}$ are shown on plate $5 \mathrm{C}$. In the two wells (EA-OT-2 and SE-OT-6) where the sand-shale combination with waste-storage potential occurs twice, a value for the $D / P R$ factor was determined for each sand occurrence. The two values, one for the upper sand and one for the lower sand, are listed in table 7 for each of the two wells. On plate $5 \mathrm{C}$, the smaller of the two numbers, which is the number representing the D/PR factor for the upper sand, was used to determine the position of lines of equal value for the D/PR factor in Unit $F$.

For the nine wells in which Unit $F$ is judged to have waste-storage potential, geohydrologic data are listed in the supplementary-data section of this report. A comparative summary of geohydrologic data for the geologic units evaluated for waste-storage purposes is given in table 4 .

\section{UNIT E, ROCKS OF CRETACEOUS AGE}

The designated type-reference section for Unit $\mathrm{E}$ (Brown, and others, 1972, p. 42, pl. 51) is a well section, 270 feet thick, in Albermarle Sound, Dare County, N.C.

In the project area, Unit $\mathrm{E}$ is generally absent in South Carolina, except in the parts of Beaufort, Charleston, and Jasper Counties, but it has a widespread distribution throughout central and southern Georgia (pl. $6 \mathrm{~A})$. It ranges in thickness from less than 50 feet in parts of South Carolina and central Georgia to more than 700 feet in parts of Early County in western Georgia. The maximum thickness measured, 713 feet, is in a well in Early County, Ga. (GA-EA-OT-3, table 6).
Unit $E$ is present in 72 of the 88 wells that make up the key-well network (pl. 6A). Unit E contains both usable and nonusable ground water whose distribution is shown on plate 6 and plate 12. In areas where Unit $E$ contains nonusable ground water, it is judged to be present in 48 of the 88 wells that make up the key-well network. In only 2 of these 48 wells is Unit $E$ judged to have waste-storage potential on the basis of the geometry of its combined sand-shale layers (pl. 6C).

The sediments of Unit $\mathrm{E}$ consist chiefly of gray to brownish-gray micaceous shale, intercalated with thin layers of fine- to medium-grained sand and sandstone and containing lenses of leached skeletal-micritic limestone. Phosphorite, pyrite, and glauconite occur commonly in the middle and lower third of the unit. Herrick (1961) and Applin and Applin (1964) provide detailed lithologic descriptions for sediments in Georgia that we include in Unit $\mathrm{E}$ in this report.

Representative geophysical-log sections and depth-ofoccurrence and thickness-distribution patterns for Unit $\mathrm{E}$ are shown on seven of the eight stratigraphic cross sections assembled on plate 1 . In areas where Unit $E$ contains nonusable ground water, the depth to the top of the unit ranges from about 2,000 feet below mean sea level in parts of Dooly County, Ga. to more than 4,400 feet below mean sea level in parts of Camden and Glynn Counties, Ga. (pl. 6A). Also, in areas of nonusable ground water, the thickness of Unit $E$ ranges from less than 100 feet in eastern and west-central Georgia to more than 300 feet in Decatur, Grady, and Seminole Counties, Ga. (pl. 6B). As shown by contours (pl. 6B), the approximate sodium chloride concentration of nonusable ground water in Unit $\mathrm{E}$ ranges from greater than $10,000 \mathrm{mg} / \mathrm{L}$ to greater than $100,000 \mathrm{mg} / \mathrm{L}$. As calculated from structure-contour and isopach maps (pl. 6A and $6 \mathrm{~B}$ ) for areas where it contains nonusable ground water (pl. 6B), Unit E covers an area of 13,653 square miles and contains a volume of sediments equivalent to 443 cubic miles. (See table 5.)

In areas where Unit $\mathrm{E}$ contains nonusable ground water (pl. 6C) and may, therefore, have waste-storage potential, the requisite sand-shale (reservoir, reservoirseal) combination, as defined on page 3, was present in two wells in Georgia as follows:

$$
\begin{array}{ll}
\text { GA-COQ-OT-1 } & \text { Colquitt County } \\
\text { GA-EA-OT-1 } & \text { Early County }
\end{array}
$$

In each well the sand-shale combination occurs once in Unit $\mathrm{E}$. The depth to the top of Unit $\mathrm{E}$ ranges from 2,738 feet (GA-EA-OT-1) to 3,040 feet (GA-COQ-OT-1) below mean sea level and averages 2,889 feet. The total thickness of Unit $E$ in these wells ranges from 200 feet (GA-COQ-OT-1) to 215 feet (GA-EA-OT-1) and averages 208 feet. 
Total sand thickness for Unit $\mathrm{E}$ in the two wells ranges from 40 feet (GA-EA-OT-1) to 58 feet (GA-COQ-OT-1) and averages 49 feet. Total shale thickness for Unit $\mathrm{E}$ in the same wells ranges from 142 feet (GA-COQ-OT-1) to 175 feet (GA-EA-OT-1) and averages 159 feet.

The thickness of Unit E's potential reservoir sands ranges from 40 feet (GA-EA-OT-1) to 58 feet (GA-COQ-OT-1) and averages 49 feet.

Unit E's potential reservoir seals, that immediately overlie reservoir sands, are about 34 feet thick in each of the two wells. Similarly, the thickness of underlying reservoir seals ranges from 20 feet (GA-COQ-OT-1) to 50 feet (GA-EA-OT-1) and averages 35 feet.

The underlying shale seals for potential reservoir sands also extend from Unit $E$ into the upper part of Unit F.

In wells where Unit $\mathrm{E}$ has waste-storage potential, the depth to the top of the potential reservoir sand ranges from 2,898 feet (GA-EA-OT-1) to 3,174 feet (GA-COQ-OT-1) below mean sea level and averages 3,036 feet. For the same wells the D/PR factor (average depth of potential reservoir sand occurrence/total thickness of Unit's potential reservoir sand) ranges from 55 (GA-COQ-OT-1) to 72 (GA-EA-OT-1) and averages 64 .

For the two wells in which Unit $E$ is judged to have waste-storage potential, geohydrologic data are listed in the supplementary-data section of this report. A comparative summary of geohydrologic data for the geologic units evaluated for waste-storage purposes is given in table 4 .

\section{UNIT D, ROCKS OF CRETACEOUS AGE}

The designated type-reference section for Unit D (Brown and others, 1972, p. 42, pl. 48) is a well section, 310 feet thick, in Washington County, N.C.

In the project area, Unit D extends from the North Carolina-South Carolina border, southwest to the Georgia-Alabama border (pl. 7A). It ranges in thickness from less than 20 feet, along the inner margin of the Georgia and South Carolina coastal plains, to more than 600 feet in parts of Beaufort and Jasper Counties, S.C. and in a block of counties in west-central Georgia. The maximum thickness measured, 678 feet, is in a well in Dooly County, Ga. (GA-DOO-OT-1, table 6).

Unit $D$ is present in 85 of the 88 wells that make up the key-well network (pl. 7A). Unit D contains both usable and nonusable ground water whose distribution is shown on plate 7 and plate 12 . In areas where Unit D contains nonusable ground water, it is judged to be present in 85 of the 88 wells that make up the key-well network. In only 3 of these 85 wells is Unit D judged to have waste-storage potential on the basis of the geometry of its combined sand-shale layers (pl. 7C).
The sediments of Unit D consist chiefly of white, gray, red, or purple, poorly sorted sand, quartzose sandstone and sandy mudstone interlayered with micaceous shale. Carbonaceous material, glauconite, pyrite, and siderite may be sparse to abundant locally. Herrick (1961) and Applin and Applin (1964) provide detailed lithologic descriptions for sediments in Georgia that we include in Unit D in this report.

Representative geophysical-log sections and depth-ofoccurrence and thickness-distribution patterns for Unit $D$ are shown on the eight stratigraphic cross sections assembled on plate 1 . In areas where Unit D contains nonusable ground water, the depth to the top of the unit ranges from about 2,300 feet below mean sea level, in parts of Baker and Mitchell Counties, Ga., to more than 4,200 feet below mean sea level in parts of Camden and Glynn Counties, Ga (pl. 7A). In areas of nonusable ground water, the thickness of Unit $D$ ranges from about 100 to 500 feet (pl.7B). As shown by contours (pl. 7B), the approximate sodium chloride concentration of nonusable ground water in Unit D ranges from greater than $10,000 \mathrm{mg} / \mathrm{L}$ to greater than $50,000 \mathrm{mg} / \mathrm{L}$. As calculated from structure-contour and isopach maps (pl. 7A and 7B) for areas where it contains nonusable ground water (pl. 7B), Unit D covers an area of 7,240 square miles and contains a volume of sediment equivalent to 473 cubic miles. (See table 5 .)

In areas where Unit $D$ contains nonusable ground water (pl. 7C) and may, therefore, have waste-storage potential, the requisite sand-shale (reservoir, reservoirseal) combination, as defined on page 3, was present in three wells located in three counties in Georgia (pl. 7C) as follows:

$\begin{array}{ll}\text { GA-CAM-OT-1 } & \text { Camden County } \\ \text { GA-EC-OT-1 } & \text { Echols County } \\ \text { GA-GLY-OT-2 } & \text { Glynn County }\end{array}$

In each of the three wells, the sand-shale combination occurs once in Unit D. In these wells the depth to the top of Unit D ranges from 3,124 (GA-EC-OT-1) to 4,080 feet (GA-GLY-OT-2) below mean sea level and averages 3,758 feet. In these wells the total thickness of Unit $D$ ranges from 200 feet (GA-EC-OT-1) to 395 feet (GA-GLY-OT-2) and averages 287 feet.

Total sand thickness for Unit $D$ in the three wells ranges from 85 feet (GA-EC-OT-1 and GA-CAM-OT-1) to 181 feet (GA-GLY-OT-2) and averages 117 feet. Total shale thickness for Unit $D$ in the same wells ranges from 115 feet (GA-EC-OT-1) to 214 feet (GA-GLY-OT-2) and averages 170 feet.

The thickness of Unit D's potential reservoir sands ranges from 85 feet (GA-EC-OT-1 and GA-CAM-OT-1) to 100 feet (GA-GLY-OT-2) and averages 90 feet. The thickness of Unit D's potential reservoir seals, that immediately overlie reservoir sands, range from 30 feet 
(GA-EC-OT-1) to 140 feet (GA-GLY-OT-2) and averages 100 feet. Similarly, the thickness of underlying reservoir seals ranges from 40 feet (GA-EC-OT-1) to 70 feet (CA-CAM-OT-1) and averages 52 feet.

In one well (GA-EC-OT-1) the sand considered to have waste-storage potential occurs principally at the top of Unit D but also extends 10 feet into overlying Unit C. The overlying shale seal for this sand occurs in Unit $\mathrm{C}$ also. For purposes of description and tabulation, the sand is listed as being within Unit $\mathrm{D}$. The overlying shale unit for well GA-CAM-OT-1 lies partly in Unit C and the overlying shale unit for well GA-GLY-OT-2 lies entirely in Unit $\mathbf{C}$.

In wells where Unit $D$ has waste-storage potential, the depth to the top of the potential reservoir sand ranges from 3,114 feet (GA-EC-OT-1) to 4,080 feet (GA-GLY-OT-2) below mean sea level and averages 3,756 feet. For the same wells the D/PR factor (depth of potential reservoir sand occurrence/total thickness of Unit's potential reservoir sand) ranges from 37 (GA-EC-OT-1) to 48 (GA-CAM-OT-1) and averages 42.

For the three wells in which Unit $D$ is judged to have waste-storage potential, geohydrologic data are listed in the supplementary-data section of this report. A comparative summary of geohydrologic data for the geologic units evaluated for waste-storage purposes is given in table 4.

\section{UNIT C, ROCKS OF CRETACEOUS AGE}

The designated type-reference section for Unit $\mathrm{C}$ (Brown and others, 1972, p. 43, pl. 25) is a well section, 410 feet thick, in Pender County, N.C.

In the project area, Unit $\mathrm{C}$ extends from the North Carolina-South Carolina border, southwest to the Georgia-Alabama border (plate $8 \mathrm{~A}$ ). It attains a maximum thickness of greater than 500 feet, chiefly in Clay, Randolf, Terrell, and Lee Counties, Ga. Elsewhere in the project area, it ranges in thickness from less than 20 to about 400 feet. The maximum thickness measured, 641 feet, is in a well in Wayne County, Ga. (GA-WAY-OT-6, table 6).

Unit $\mathrm{C}$ is present in 84 of the 88 wells that make up the key-well network (pl. 8A). Unit C contains both usable and nonusable ground water whose distribution is shown on plate 8 and plate 12 . In areas where Unit C contains nonusable ground water, it is judged to be present in 39 of the 88 wells that make up the key-well network. On the basis of the geometry of its combined sandshale layers, Unit $C$ was judged to have no waste-storage potential in the areas where it contains nonusable ground water.

In one well (GA-CAM-OT-1) a shale interval in Unit $\mathrm{C}$ is part of an underlying shale seal for a sand with reservoir potential in Unit B.
The sediments of Unit $\mathrm{C}$ consist chiefly of black- to gray or buff-colored micaceous marl and fine- to mediumto coarse-grained, highly glauconitic sand. In central and southern Georgia the marl exhibits a chalky character in many well sections. Herrick (1961) and Applin and Applin (1964) provide detailed lithologic descriptions for sediments in Georgia that we include in Unit $\mathrm{C}$ in this report.

Representative geophysical-log sections and depth-ofoccurrence and thickness- distribution patterns for Unit $\mathrm{C}$ are shown on the eight stratigraphic cross sections assembled on plate 1 . In areas where Unit $C$ contains nonusable ground water, the depth to the top of the unit ranges from about 1,900 feet below mean sea level in Miller and Mitchell Counties, Ga., to more than 3,700 feet below mean sea level in Camden and Glynn Counties, Ga. (pl. 8A). In areas of nonusable ground water, the thickness of Unit $\mathrm{C}$ ranges from 300 to 500 feet, except locally in a part of Wayne County, Ga., where the unit may attain a thickness of about 600 feet (plate 8B). As shown by contours (plate $8 \mathrm{~B}$ ), the approximate sodium chloride concentration of nonusable ground water in Unit $\mathrm{C}$ ranges from greater than $10,000 \mathrm{mg} / \mathrm{L}$ to greater than $15,000 \mathrm{mg} / \mathrm{L}$. As calculated from structure-contour and isopach maps (pl. 8A and 8B) for areas where it contains nonusable ground water, Unit $C$ covers an area of 8,876 square miles and contains a volume of sediment equivalent to 639 cubic miles. (See table 5.)

In none of the 39 wells drilled in areas where Unit C contained nonusable ground water did the unit contain at least 20-foot thick layers of sand or sandstone overlain and underlain by at least 20-foot thick layers of clay or shale. Therefore, for purposes of this report, Unit $\mathrm{C}$ is judged to have no waste-storage potential in the project area.

\section{UNIT B, ROCKS OF CRETACEOUS AGE}

The designated type-reference section of Unit $B$ (Brown and others, 1972, p. 44, pl. 48) is a well section, 468 feet thick, in Carteret County, N.C.

In the project area, Unit B extends from the North Carolina-South Carolina border, southwest to the Georgia-Alabama border (pl. 9A). The unit attains a maximum thickness of from 600 to 750 feet in two northeasttrending depocenters, located in west-central and eastcentral Georgia, from whence it thins to both the northwest and the southeast. It is relatively thin across segments of the central Georgia uplift where it ranges in thickness from 100 to $\mathbf{4 0 0}$ feet. The maximum thickness measured, 715 feet, is in a well in Dougherty County, Ga. (GA-DOG-OT-1, table 6).

Unit $B$ is present in 85 of the 88 wells that make up the key-well network (pl. 9A). Unit B contains both us- 
able and nonusable ground water whose distribution is shown on plate 9 and plate 11. In areas where Unit B contains nonusable ground water, it is judged to be present in 27 of the 88 wells that make up the key-well network (pl. 9B). In only 1 of these 27 wells is Unit B judged to have waste-storage potential on the basis of the geometry of its combined sand-shale layers (pl. 9C).

The sediments of Unit B consist chiefly of light-gray to brown micaceous marl, gray sandy clay and shale, and fine- to coarse-grained quartz sand. Carbonaceous material is present in most sections, some individual layers may contain as much as 80-90 percent. Locally, sandy, micritic-skeletal limestone may be present as thin beds. Glauconite usually is present in trace amounts but may constitute as much as 50 percent of some 10 -foot sample intervals. Nodular black and brown phosphorite is present in trace amounts in some sand layers. Herrick (1961) and Applin and Applin (1964) provide detailed lithologic descriptions for sediments in Georgia that we include in Unit B.

Representative geophysical-log sections and depth-ofoccurrence and thickness- distribution patterns for Unit B are shown on the eight stratigraphic cross sections assembled on plate 1 . In areas where Unit B contains nonusable ground water, the depth to the top of the unit ranges from about 1,700 feet below mean sea level, in parts of Decatur and Grady Counties, Ga., to more than 3,400 feet below mean sea level, in parts of Camden and Glynn Counties, Ga. (pl. 9A). In areas of nonusable ground water, the thickness of Unit B ranges from about 100 feet to more than 500 feet (pl. 9B). As shown by contours (pl. 9B), the approximate sodium chloride concentration of nonusable ground water in Unit $B$ ranges from greater than $10,000 \mathrm{mg} / \mathrm{L}$ to greater than 50,000 $\mathrm{mg} / \mathrm{L}$. As calculated from structure-contour and isopach maps (pl. 9A and 9B) for areas where it contains nonusable ground water, Unit B covers an area of 7,232 square miles and contains a volume of sediments equivalent to 411 cubic miles. (See table 5.)

In areas where Unit B contains nonusable ground water (pl. 9C) and may, therefore, have waste-storage potential, the requisite sand-shale (reservoir, reservoirseal) combination, as defined on page 3 , was present in only one well (GA-CAM-OT-1) in Camden County, Ga. (pl. 9C). In this well the depth to the top of Unit B is 3,315 feet below mean sea level and the unit is 310 feet thick. The total thickness comprises 115 feet (37 percent) shale and 195 feet (63 percent) sand.

One sand layer, 195 feet thick, immediately overlain by a shale layer 80 feet thick and underlain by a shale layer 95 feet thick, was judged to have waste-storage potential. In this well the depth to the top of the potential waste-reservoir sand, that is present in the middle and lower thirds of Unit $B$, is 3,415 feet below mean sea level. The D/PR factor (average depth of potential reservoir sand occurrence/total thickness of Unit's potential reservoir sand) is $\mathbf{1 7 . 5}$.

Geohydrologic data for the one well section in Unit B judged to have waste-storage potential are listed in the supplementary-data section of this report. A comparative summary of the data from this and other wells that have sections with waste-storage potential and which penetrate one or more of geologic units evaluated for waste-storage purposes is listed in table 4.

\section{UNIT A, ROCKS OF CRETACEOUS AGE}

The designated type-reference section for Unit A (Brown and others, 1972, p. 45, pl. 24) is a well section, 386 feet thick, in New Hanover County, N.C.

In the project area, Unit A extends from the North Carolina-South Carolina border, southwest to the Georgia-Alabama border (pl. 10A). The unit attains a maximum thickness, greater than 1,000 feet, in parts of Glynn and McIntosh Counties, Ga., that lie within the Savannah (Southeast Georgia) basin (fig. 1). Unit A is absent or less than 50 feet thick in a tier of counties in southern Georgia that border Florida. Throughout western and central Georgia and the ocean-bordering counties in South Carolina, Unit A ranges in thickness from about 200 to 400 feet. The maximum thickness measured, 925 feet, is in a well in Glynn County, Ga. (GA-GLY-OT-7, table 6).

Unit A is present in 77 of the 88 wells that make up the key-well network (pl. 10A). Unit A contains both usable and nonusable ground water whose distribution is shown on plate 10 and plate 11 . In areas where Unit $A$ is judged to contain nonusable ground water, it is present in 17 of the 88 wells that make up the key-well network. In only 1 of these 17 wells is Unit A judged to have waste-storage potential on the basis of the geometry of its combined sand-shale layers.

The sediments of Unit A consist chiefly of grày, sandy, micaceous clay interlayered with gray to white mediumto fine-grained quartz sand and gray marl. Algal limestone and chalk are the dominant sediments in Unit A in parts of southeast Georgia. Thin beds of sandy, skeletal limestone containing phosphorite pebbles occur commonly. Most sections are sparsely to heavily glauconitic. Herrick (1961) and Applin and Applin (1964) provide detailed lithologic descriptions for sediments in Georgia that we include in Unit A in this report.

Representative geophysical-log sections and depth-ofoccurrence and thickness-distribution patterns for Unit $A$ are shown on the eight stratigraphic cross sections assembled on plate 1 . In areas where Unit A contains nonusable ground water, the depth to the top of the unit ranges from about 1,500 feet below mean sea level, in 
parts of Colquitt County, Ga., to more than 3,100 feet below mean sea level, in parts of Camden and Charlton Counties, Ga. (pl. 10A). In areas of nonusable ground water, the thickness of Unit A ranges from 100 to 400 feet except in a local depocenter in parts of Glynn and McIntosh Counties, Ga. where it may attain a thickness of about 1,000 feet (pl. 10B). As shown by contours (pl. 10B), the approximate sodium chloride concentration of nonusable ground water in Unit A ranges from greater than $10,000 \mathrm{mg} / \mathrm{L}$ to greater than $25,000 \mathrm{mg} / \mathrm{L}$. As calculated from structure-contour and isopach maps (pl.10A and 10B) for areas where it contains nonusable ground water, Unit A covers an area of 5,824 square miles and contains a volume of sediments equivalent to 349 cubic miles. (See table 5.)

In areas where Unit A contains nonusable ground water (pl. 10C) and may, therefore, have waste-storage potential, the requisite sand-shale (reservoir, reservoirseal) combination, as defined on page 3 , was present in only one well (GA-GLY-OT-7) in Glynn County, Ga. (pl. $10 \mathrm{C})$. In this well the depth to the top of Unit A is 2,346 feet below mean sea level and the unit is 925 feet thick. The total thickness is made up of 155 feet (17 percent) sand, 400 feet (43 percent) shale, and 370 feet (40 percent) carbonate rock.

One sand layer, 155 feet thick, immediately overlain by a shale layer 205 feet thick and underlain by a shale layer 42 feet thick, was judged to have waste-storage potential, in terms of the criteria for such established in this report. In this well the depth to the top of the potential waste-reservoir sand is 3,116 feet below mean sea level. The D/PR factor (average depth of potential reservoir sand occurrence/total thickness of Unit's potential-reservoir sand) is 20 .

Geohydrologic data for the one well section in Unit A judged to have waste-storage potential are listed in the supplementary data section of this report. A comparative summary of the data from this and other wells that have sections with waste-storage potential and which penetrated one or more of the geologic units evaluated for waste-storage purposes is listed in table 4.

\section{SUMMARY}

Subsurface data, derived from study of well cuttings, cores, and geophysical logs from about 400 wells, 88 of which make up a key-well network, were used to develop the concept and definition of a waste-storage "operational unit." The component parts of the unit were mapped in the subsurface by direct and indirect methods. The waste-storage "operational unit" is defined as follows:

\begin{abstract}
A sand or sandstone layer, 20 feet or greater in thickness, that is directly underlain and overlain by a shale or clay layer, 20 feet or greater in thickness, and which occurs in Units A, B, C, D, E, F, G, or H, where each of these units contains waters that have a sodium-chloride concentration greater than $10,000 \mathrm{mg} / \mathrm{L}$.
\end{abstract}

For mapping purposes, the definition contains three determinant components. They are: (1) the distribution of the eight regional chronostratigraphic Units (A through $H(?))$ in the subsurface, (2) the distribution within each unit of ground water that has a sodium chloride concentration greater than $10,000 \mathrm{mg} / \mathrm{L}$, and (3) within each unit, the presence or absence of a combination of sand and shale layers that have waste-storage potential.

The distribution and nature of the three determinant components of the waste-storage "operational unit" are shown by means of maps and by tables that contain data derived from interpretation of the maps. The basic set of maps prepared for each of the eight regional chronostratigraphic units judged to have waste-storage potential includes:

1. The areal distribution of the unit in the subsurface.

2. Structural contours on the top of the unit: mean sea level datum.

3. Delineation of areas within the unit where the calculated sand-shale ratio is one or greater.

4. Delineation of areas where the unit contains nonusable ground water defined as having an approximate sodium chloride concentration $10,000 \mathrm{mg} / \mathrm{L}$ or greater.

5. Contoured thickness of the unit in areas where it contains nonusable ground water.

6. Contoured values for the approximate sodium chloride concentration of its nonusable ground water.

The maps, tables, and basic-supportive data make available to management a wide range of quantitative information that can be used to evaluate waste-storage potential in the project area and in component parts of its sediment mass. The information can be used to help select the most favorable areas with waste-storage potential for detailed examination.

As developed in this report, the concept and utilization of an "operational unit" should have value as a quantitative exploration technique in subsurface investigations other than those that involve waste storage. For example, in conjunction with the use of other carefully defined "operational units" that contain mappable geohydrologic parameters, the concept should have particular utility 
for purposes of determining the spatial distribution of the various amounts and types of usable ground water that may be present in both local and regional aquifer systems.

\section{SELECTED REFERENCES}

Applin, E. R., 1955, A biofacies of Woodbine Age in the southeast Gulf Coast regions: U.S. Geol. Survey Prof. Paper 264-I, p. I187-I197, pls. 48, 49.

Applin, E. R., and Applin, P. L., 1964, Logs of selected wells in the coastal plain of Georgia: Georgia Geol. Survey Bull. 74, 229 p.

Applin, P. L., 1951, Preliminary report on buried Pre-Mesozoic rocks in Florida and adjacent states: U.S. Geol. Survey Circ. 91, $28 \mathrm{p}$.

Applin, P. L., and Applin, E. R., 1944, Regional subsurface stratigraphy and structure of Florida and southern Georgia: Am. Assoc. Petroleum Geologists Bull., v. 28, p. 1673-1753.

1947, Regional subsurface stratigraphy and correlation of middle and early Upper Cretaceous rocks in Alabama, Georgia and north Florida: U.S. Geol. Survey Oil and Gas Inv., (Prelim.) Chart 26.

1965, The Comanche Series and associated rocks in the subsurface of central and south Florida: U.S. Geol. Survey Prof. Paper 447, $84 \mathrm{p}$.

- 1967, The Gulf Series in the subsurface in northern Florida and southern Georgia: U.S. Geol. Survey Prof. Paper 524-G, 35 p., 4 figs., 8 pls.

Arden, D. D. Jr., 1974, A geophysical profile in the Suwannee Basin, northwestern Florida, in Symposium on the Petroleum Geology of the Georgia Coastal Plain: Georgia Geol. Survey Bull. 87, p. 111-122.

Bonini, W. E., and Woolard, G. P., 1960, Subsurface geology of the North Carolina-South Carolina Coastal Plain from seismic data: Am. Assoc. Petroleum Geologists Bull., v. 44, p. 298-315.

Bridge, J., and Berdan, J. M., 1952, Preliminary correlations of the Paleozoic rocks from test wells in Florida and adjacent parts of Georgia and Alabama, in Florida Geol. Survey Guidebook: Assoc. Am. State Geologists 44th Ann. Mtg. Field Trip, 1952, p. $29-38$.

Brown, D. L., 1971, Techniques for quality-of-water interpretations from calibrated geophysical logs, Atlantic Coastal Plain: Ground Water, v. 9 , no. $4,14 \mathrm{p}$.

Brown, P. M., 1974, Subsurface correlation of Mesozoic Rocks in Georgia, in Symposium on the Petroleum Geology of the Georgia Coastal Plain: Georgia Geol. Survey Bull. 87, p. 45-59.

Brown, P. M., Miller, J. A., and Swain, F. M., 1972, Structural and stratigraphic framework, and spatial distribution of permeability of the Atlantic Coastal Plain, North Carolina to New York: U.S. Geol. Survey Prof. Paper 796, 79 p., 13 figs., 59 pls.

Brown, P. M., and Reid, M. S., 1976, Geologic evaluation of wastestorage potential in selected segments of the Mesozoic aquifer system below the zone of fresh water, Atlantic Coastal Plain, North Carolina through New Jersey: U.S. Geol. Survey Prof. Paper 881,47 p., 5 figs., 10 pls.

Callahan, J. T., 1964, The yield of sedimentary aquifers of the coastal plain, southeast river basins: U.S. Geol. Survey WaterSupply Paper $1669-\mathrm{W}, 56 \mathrm{p}$.

Cramer, H. R., 1969, Structural features of the Coastal Plain of Georgia: Southeastern Geology, v. 10, no. 2, p. 111-123.

1974, Isopach and lithofacies analysis of the Cretaceous and
Cenozoic rocks of the Coastal Plain of Georgia, in Symposium on the Petroleum Geology of the Georgia Coastal Plain: Georgia Geol. Survey Bull. 87, p. 21-43.

Forgotson, J. M., Jr., 1958, A correlation and regional stratigraphic analysis of the formations of the Trinity Group of the Comanchean Cretaceous of the Gulf Coastal Plain-and the genesis and petrography of the Ferry Lake anhydrite: Gulf Coast Assoc. Geol. Socs. Trans., v. 6, p. 91-108.

1963, Depositional history and paleotectonic framework of the Comanchean Cretaceous Trinity Stage, Gulf Coast area: Am. Assoc. Petroleum Geologists Bull., v. 47, p. 69-103.

Herrick, S. M., 1961, Well logs of the Coastal Plain of Georgia: Georgia Geol. Survey Bull. 70, 462 p.

Herrick, S. M., and Vorhis, R. C., 1963, Subsurface geology of the Georgia Coastal Plain: Georgia Geol. Survey Inf. Circ. 25, 78 p., 28 figs.

Hull, J. P. D., Jr., 1962, Cretaceous Suwannee strait, Georgia and Florida: Am. Assoc. Petroleum Geologists Bull., v. 46, p. 118-122.

King, P. B., 1961, Summary reports on selected wells penetrating Paleozoic rocks in the southeastern states, in Flawn, P. T., and others, the Ouachita system: Texas Univ. Bur. Econ. Geology Pub. 6120, pt. 3 of Appendix, p. 347-361.

McLean, J. D., Jr., 1960, Stratigraphy of the Parris Island area, South Carolina: McLean Paleont. Lab. Rept., no. 4, 70 p.

Maher, J. C., 1965, Correlations of subsurface Mesozoic and Cenozoic rocks along the Atlantic Coast: Am. Assoc. Petroleum Geologists, Cross Sec. Pub. 3, 18 p., 1 fig., 17 pls.

-1971, Geologic framework and petroleum potential of the Atlantic Coastal Plain and Continental Shelf: U.S. Geol. Survey Prof. Paper 659, 98 p., 8 figs., 17 pls.

Marine, I. W., and Siple, G. E., 1974, Buried Triassic basin in the central Savannah River area, South Carolina and Georgia: Geol. Soc. American Bull., v. 85, p. 311-320.

Marsalis, W. E., 1970, Petroleum exploration in Georgia: Georgia Geol. Survey Inf. Circ. 38, 48 p.

Milton, Charles, 1954, Basement cores from Georgia, Alabama and Florida (abs): Geol. Soc. America Bull., v. 65, p. 1364.

Milton, Charles, and Grasty, R., 1969, "Basement" rocks of Florida and Georgia: Am. Assoc. Petroleum Geologists Bull., v. 53, p. 2483-2493.

Milton, Charles, and Hurst, V. A., 1965, Subsurface "Basement" rocks of Georgia: Georgia Geol. Survey Bull. 76, 56 p.

Murray, G. E., Jr., 1956, Relationships of Paleozoic structures to large anomalies of coastal element of eastern North America: Gulf Coast Assoc. Geol. Socs. Trans., v. 6, p. 13-24. 1961, Geology of the Atlantic and Gulf Coastal province of North America: New York, Harper and Row, $692 \mathrm{p}$.

Olson, N. K., and Glowacz, M. E., 1977, Petroleum geology and oil and gas potential of South Carolina: Am. Assoc. Petroleum Geologists Bull., v. 61 , p. 331-343.

Patterson, S. H., and Herrick, S. M., 1971, Chattahoochee anticline, Appalachicola embayment, Gulf trough and related structural features, southwestern Georgia, fact or fiction: Georgia Geol. Survey Inf. Circ. $41,16 \mathrm{p}$.

Pressler, E. D., 1947, Geology and occurrence of oil in Florida: Am. Assoc. Petroleum Geologists Bull., v. 31, p. 1851-1862.

Prettyman, T. M., and Cave, H. A., 1923, Petroleum and natural gas possibilities in Georgia: Georgia Geol. Survey Bull. 40, 167 p.

Rainwater, E. H., 1968, Geological history and oil and gas potential of the central Gulf Coast: Gulf Coast Assoc. Geol. Socs. Trans., v. 18 , p. $124-165$.

1970a, Regional stratigraphy and petroleum potential of the 
Gulf Coast Lower Cretaceous: Gulf Coast Assoc. Geol. Socs. Trans., v. 20, p. 145-157.

$1970 \mathrm{~b}$, Stratigraphy and petroleum potential of peninsular Florida and southern Georgia: Gulf Coast Assoc. Geol. Socs. Trans., v. 20, p. 49-59.

Richards, H. G., 1945, Subsurface stratigraphy of the Atlantic Coastal Plain between New Jersey and Georgia: Am. Assoc. Petroleum Geologists Bull., v. 29, p. 885-955.

1948 , Studies on the geology and paleontology of the Atlantic Coastal Plain: Acad. Nat. Sci. Philadelphia Proc., v. 100, p. 39-76.

1967, Stratigraphy of Atlantic Coastal Plain between Long Island and Georgia: Review: Am. Assoc. Petroleum Geologists Bull., v. 51, p. 2400-2429.

Sever, C. W., Jr., 1964-65, The Chattahoochee anticline in Georgia: Georgia Mineral Newsletter, v. 17, p. 39-43.

1965, Ground-water resources and geology of Seminole, Decatur, and Grady Counties, Georgia: U.S. Geol. Survey WaterSupply Paper $1809-\mathbf{Q}, 30$ p.

Siple, G. E., 1958, Stratigraphic data from selected oil tests and water wells in the South Carolina Coastal Plain: South Carolina
State Devel. Bd., Div. Geology Geol. Notes, v. 2, p. 62-68.

1959, Guidebook for the South Carolina Coastal Plain field trip of the Carolina Geological Society, November 16-17, 1959: South Carolina State Devel. Bd., Div. Geology Bull., no. 24, 27 p.

1967, Geology and ground water of the Savannah River Plant and vicinity, South Carolina: U.S. Geol. Survey Water-Supply Paper 1841, $113 \mathrm{p}$.

Stephenson, L. W., 1914, A deep well at Charleston, South Carolina: U. S. Geol. Survey Prof. Paper 90-H, p. H69-H94.

1928, Structural features of the Atlantic and Gulf Coastal Plain: Geol. Soc. America Bull., v. 39, p. 887-900.

Walker, W. R., and Cox, W. E., 1976, Deep well injection of industrial wastes: Government controls and legal constraints: Virginia Water Resources Research Center, Blacksburg, Virginia, $163 \mathrm{p}$.

Woolard, G. P., Bonini, W. E., and Meyer, R. P., 1957, A seismic refraction study of the subsurface geology of the Atlantic Coastal Plain and continental shelf between Virginia and Florida: Wisconsin Univ. Dept. Geology Rept., Contract N7 ONR-28512, $128 \mathrm{p}$. 
SUPPLEMENTARY DATA 
TABLE 6.-Well number, name, location, elevation, depth, and stratigraphic

\begin{tabular}{|c|c|c|c|c|c|c|c|c|c|}
\hline \multirow[b]{2}{*}{ Well number } & \multirow[b]{2}{*}{ Well name } & $\begin{array}{c}\text { Coordinate } \\
\text { location }\end{array}$ & \multirow[b]{2}{*}{$\begin{array}{c}\text { - Elevation of Elevation } \\
\text { measuring } \\
\text { point (f) ground } \\
\text { level }(\mathbf{\Omega})\end{array}$} & \multirow[b]{2}{*}{$\begin{array}{l}\text { Total depth } \\
\text { (ft) }\end{array}$} & \multicolumn{2}{|c|}{ Unit $\mathrm{H}(?)$} & \multicolumn{2}{|c|}{ Unit $G(?)$} & Unit $F$ \\
\hline & & Long. & & & $\begin{array}{l}\text { Depth to } \\
\text { top below } \\
\text { mean sea } \\
\text { level (ff) }\end{array}$ & $\begin{array}{c}\text { Thickness } \\
(\mathrm{ft})\end{array}$ & $\begin{array}{l}\text { Depth to } \\
\text { top below } \\
\text { mean sea } \\
\text { level (ft) }\end{array}$ & $\begin{array}{c}\text { Thickness } \\
\text { (ft) }\end{array}$ & $\begin{array}{l}\text { Depth to } \\
\text { top below Thickness } \\
\begin{array}{ll}\text { mean sea } & (\mathrm{f})\end{array}\end{array}$ \\
\hline
\end{tabular}

\begin{tabular}{|c|c|c|c|c|c|c|c|c|c|c|c|c|}
\hline & & . & & & & & & & & & & \\
\hline GA-AP-OT-1 & $\begin{array}{l}\text { Felsenthal-Weatherford, } \\
\text { Mrs. W. F. Bradley }\end{array}$ & $31^{\circ} 52^{\prime} 55^{\prime \prime \prime}$ & $\begin{array}{l}82^{\circ} 23^{\prime} 00^{\prime \prime} \\
. \quad .\end{array}$ & 231 & 219 & 4,098 & abs. & - & abs. & - & 3,669 & 175 \\
\hline
\end{tabular}

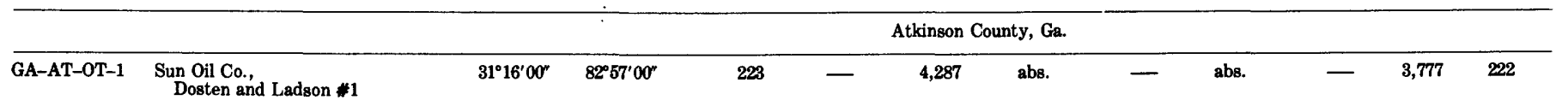

\begin{tabular}{|c|c|c|c|c|c|c|c|c|c|c|c|c|}
\hline \multirow[b]{2}{*}{ GA-BRA-0T-1 } & \multirow[b]{2}{*}{$\begin{array}{l}\text { Humble Oil \& Refining Co. } \\
\text { *ST-1 W. F. Helleman }\end{array}$} & \multicolumn{11}{|c|}{ Brantley County, Ga. } \\
\hline & & $31^{\circ} 17^{\prime} 23^{\prime \prime}$ & $81^{\circ} 57^{\prime} 15^{\prime \prime}$ & 52 & 42 & 4,512 & - & - & - & - & 4,418 & $>42$ \\
\hline & & \multicolumn{11}{|c|}{ Brooks County, Ga. } \\
\hline \multirow[t]{2}{*}{ GA-BRO-OT-1 } & $\begin{array}{l}\text { D. E. Hughes Co., } \\
\text { \#1-B Rogers Sr. }\end{array}$ & $30^{\circ} 57^{\prime} 16^{\prime \prime}$ & $83^{\circ} 36^{\prime} 44^{\prime \prime}$ & 133 & 123 & 3,850 & - & - & - & - & 3,412 & $>305$ \\
\hline & & \multicolumn{11}{|c|}{ Calhoun County, Ga. } \\
\hline GA-CAL-OT-1 & $\begin{array}{l}\text { Sowega Minerals, } \\
\text { J. W. West No. } 1\end{array}$ & $31^{\circ} 33^{\prime} 55^{\prime \prime}$ & $84^{\circ} 48^{\prime} 15^{\prime \prime}$ & 345 & - & 5,265 & 4,365 & 480 & 3,673 & 692 & 2,517 & 1,156 \\
\hline
\end{tabular}

\begin{tabular}{|c|c|c|c|c|c|c|c|c|c|c|c|c|}
\hline \multirow[b]{2}{*}{ GA-CAM-OT-1 } & \multirow[b]{2}{*}{$\begin{array}{l}\text { The California Co, } \\
\text { John A. Buie } * 1\end{array}$} & \multicolumn{11}{|c|}{ Camden County, Ga. } \\
\hline & & $31^{\circ} 02^{\prime} 41^{\prime \prime}$ & $81^{\circ} 53^{\prime} 03^{\prime \prime}$ & 65 & - & 4,947 & abs. & - & abs. & - & 4,385 & 224 \\
\hline GA-CAM-OT-2 & $\begin{array}{l}\text { Pan American Petroleum Corp., } \\
\text { *1-C Union Camp }\end{array}$ & $30^{\circ} 50^{\prime} 42^{\prime \prime}$ & $81^{\circ} 44^{\prime} 10^{\prime \prime}$ & 37 & - & 4,610 & abs. & - & abs. & - & 4,373 & 132 \\
\hline \multirow[t]{2}{*}{ GA-CAM-OT-3 } & $\begin{array}{l}\text { Pan American Petroleum Corp., } \\
\text { \#1-B Union Camp }\end{array}$ & $30^{\prime} 50^{\prime} 45^{\prime \prime}$ & $81^{\circ} 51^{\prime} 30^{\prime \prime}$ & 28 & 14 & 4,710 & abs. & - & abs. & - & 4,347 & 170 \\
\hline & & \multicolumn{11}{|c|}{ Chariton County, Ga. } \\
\hline GA-CHR-OT-1 & $\begin{array}{l}\text { South Penn Oil Co. } \\
\$ 1 \text { 0. C. Mizell }\end{array}$ & $30^{\circ} 47^{\prime} 28^{\prime \prime}$ & $81^{\circ} 59^{\prime} 25^{\prime \prime}$ & 36 & 25 & 4,600 & abs. & - & abs. & - & 4,324 & 130 \\
\hline
\end{tabular}

\begin{tabular}{|c|c|c|c|c|c|c|c|c|c|c|c|c|}
\hline \multirow[b]{2}{*}{ GA-CHA-T-3 } & \multirow[b]{2}{*}{ Savannah Ports Authority } & \multicolumn{11}{|c|}{ Chatham County, Ga. } \\
\hline & & $32^{\circ} 07^{\prime} 01^{\prime \prime}$ & $81^{\circ} 13^{\prime} 19^{\prime \prime}$ & 20 & 20 & 3,440 & - & - & - & - & - & - \\
\hline & & \multicolumn{11}{|c|}{ Clinch County, Ga. } \\
\hline GA-CLI-OT-1 & $\begin{array}{l}\text { Wiley P. Ballard, Jr., } \\
\text { Timber Products Co. \#1-A }\end{array}$ & $31^{\circ} 09^{\prime} 05^{\prime \prime}$ & $82^{\circ} 51^{\prime} 50^{\prime \prime}$ & 215 & 205 & 4,182 & abs. & - & abs. & - & 3,835 & 110 \\
\hline GA-CLI-OT-2 & $\begin{array}{l}\text { Luke Grace Drilling Co., } \\
\text { *1 Lem Griffis }\end{array}$ & $30^{\circ} 47^{\prime} 00^{\prime \prime}$ & $82^{\circ} 26^{\prime} 27^{\prime \prime}$ & 119 & 110 & 4,088 & abs. & - & abs. & - & 3,671 & 53 \\
\hline GA-CLI-OT-3 & $\begin{array}{l}\text { Hunt Oil Co., } \\
\text { Alice Musgrove } \# 1\end{array}$ & $30^{\circ} 51^{\prime} 20^{\prime \prime}$ & $82^{\circ} 43^{\prime} 17^{\prime \prime}$ & 148 & 138 & 4,088 & abs. & - & abs. & 一 & 3,632 & 143 \\
\hline GA-CLI-OT-4 & $\begin{array}{l}\text { Hunt Oil Co. } \\
\text { Alice Musgrove \#2 }\end{array}$ & $305^{\prime} 38^{\prime \prime}$ & $82^{\circ} 42^{\prime} 30^{\circ}$ & 171 & 161 & 3,410 & - & - & - & - & - & - \\
\hline \multirow[t]{2}{*}{ GA-CLI-OT-5 } & $\begin{array}{l}\text { Sun Oil Co. } \\
\text { W. J. Barlow *1 }\end{array}$ & $30^{\circ} 55^{\prime} 42^{\prime \prime}$ & $82^{\circ} 47^{\prime} 53^{\prime \prime}$ & 177 & 167 & 3,848 & abs. & - & abs. & - & 3,601 & 57 \\
\hline & & \multicolumn{11}{|c|}{ Coffee County, Ga. } \\
\hline GA-COF-OT-1 & Carpenter Oil Co., & $31^{\circ} 42^{\prime} 55^{\prime \prime}$ & $82^{\circ} 53^{\prime} 50^{\prime \prime}$ & 304 & 299 & 3,556 & - & - & - & - & - & - \\
\hline GA-COF-OT-2 & $\begin{array}{l}\text { Carpenter Oil Co., } \\
\text { Terrell Thurman } \# 1\end{array}$ & $31^{\circ} 42^{\prime} 45^{\prime \prime}$ & $82^{\circ} 53^{\prime} 39^{\prime \prime}$ & 318 & 308 & 4,129 & abs. & - & abs. & - & 3,417 & 375 \\
\hline GA-COF-OT-3 & $\begin{array}{l}\text { Carpenter Oil Co. } \\
\text { J. H. Knight } \# 1\end{array}$ & $31^{\circ} 41^{\prime} 07^{\prime \prime}$ & $82^{\circ} 53^{\prime} 19^{\prime \prime}$ & 305 & - & 4,151 & abs. & - & abs. & - & 3,367 & 438 \\
\hline \multirow[t]{2}{*}{ GA-COF-OT-8 } & $\begin{array}{l}\text { Chevron Oil Co., } \\
\text { Oveda Fussell }\end{array}$ & $31^{\circ} 27^{\prime} 05^{\prime \prime}$ & $83^{\circ} 08^{\prime} 06^{\prime \prime}$ & 295 & 280 & 4,334 & abs. & - & abs. & - & 3,425 & 580 \\
\hline & & \multicolumn{11}{|c|}{ Colquitt County, Ga. } \\
\hline GA-COQ-OT-1 & $\begin{array}{l}\text { R. T. Adams, } \\
\text { D. G. Arrington \#1 }\end{array}$ & $31^{\circ} 11^{\prime} 0 T^{\prime}$ & $83^{\circ} 54^{\prime} 00^{\prime \prime}$ & 270 & 260 & 4,904 & - & - & 4,150 & $>484$ & 3,240 & 910 \\
\hline
\end{tabular}


data for the 88 wells that make up the key-well network

\begin{tabular}{|c|c|c|c|c|c|c|c|c|c|c|c|c|}
\hline \multirow[b]{2}{*}{ Well number } & \multirow[b]{2}{*}{ Well name } & \multicolumn{2}{|c|}{ Unit $\mathbf{E}$} & \multicolumn{2}{|c|}{ Unit $\mathbf{D}$} & \multicolumn{2}{|c|}{ Unit C } & \multicolumn{2}{|c|}{ Unit B } & \multicolumn{2}{|c|}{ Unit $\mathbf{A}$} & \multirow[b]{2}{*}{ Remarks } \\
\hline & & $\begin{array}{l}\text { Depth to } \\
\text { top below } \\
\text { mean sea } \\
\text { level (ft) }\end{array}$ & $\begin{array}{c}\text { Thickness } \\
\text { (ft) }\end{array}$ & $\begin{array}{l}\text { Depth to } \\
\text { top below } \\
\text { mean sea } \\
\text { level (ft) }\end{array}$ & $\begin{array}{l}\text { Thickness } \\
\text { (ft) }\end{array}$ & $\begin{array}{l}\text { Depth to } \\
\text { top below } \\
\text { mean sea } \\
\text { level (ft) }\end{array}$ & $\begin{array}{c}\text { Thickness } \\
\text { (ft) }\end{array}$ & $\begin{array}{l}\text { Depth to } \\
\text { top below } \\
\text { mean sea } \\
\text { level }(\mathrm{ft})\end{array}$ & $\begin{array}{l}\text { Thickness } \\
\text { (ft) }\end{array}$ & $\begin{array}{l}\text { Depth to } \\
\text { top below } \\
\text { mean sea } \\
\text { level (ft) }\end{array}$ & $\begin{array}{l}\text { Thickness } \\
\text { (ft) }\end{array}$ & \\
\hline & & & \multicolumn{10}{|c|}{ Appling County, Ga. } \\
\hline \multirow[t]{2}{*}{ GA-AP-OT-1 } & $\begin{array}{l}\text { Felsenthal-Weatherford, } \\
\text { Mrs. W. F. Bradley } \# 1\end{array}$ & 3,521 & 148 & 3,209 & 312 & 2,774 & 435 & 2,201 & 573 & 1,819 & 382 & $\begin{array}{l}\text { Section } \mathrm{E}-\mathrm{E}^{\prime} \\
\text { Top, Triassic(?), below } \\
\text { mean sea level } \\
\text { (feet): } 3,844(?)\end{array}$ \\
\hline & & & \multicolumn{10}{|c|}{ Atkinson County, Ga. } \\
\hline GA-AT-OT-1 & $\begin{array}{l}\text { Sun Oil Co., } \\
\text { Dosten and Ladson } * 1\end{array}$ & 3,497 & 280 & 3,031 & 466 & 2,437 & 594 & 2,157 & 280 & 1,582 & 575 & $\begin{array}{l}\text { Section D-D' } \\
\text { Potential waste-storage } \\
\text { section. Top, Paleozoic, } \\
\text { below mean sea level } \\
\text { (feet):3,999 }\end{array}$ \\
\hline
\end{tabular}

\begin{tabular}{|c|c|c|c|c|c|c|c|c|c|c|c|c|}
\hline \multirow[b]{2}{*}{ GA-BRA-OT-1 } & \multirow[b]{2}{*}{$\begin{array}{l}\text { Humble Oil \& Refining Co. } \\
* \text { ST-1 W. F. Helleman }\end{array}$} & \multirow[b]{2}{*}{4,278} & \multicolumn{10}{|c|}{ Brantley County, Ga. } \\
\hline & & & 140 & 4,038 & 240 & 3,628 & 410 & 3,123 & 505 & 2,408 & 715 & \\
\hline & & & \multicolumn{10}{|c|}{ Brooks County, Ga. } \\
\hline \multirow[t]{2}{*}{ GA-BRO-OT-1 } & $\begin{array}{l}\text { D. E. Hughes Co., } \\
\text { \#1-B Rogers Sr. }\end{array}$ & 3,227 & 185 & 2,877 & 350 & 2,467 & 410 & 2,089 & 378 & 2,067 & 22 & \\
\hline & & & \multicolumn{10}{|c|}{ Calhoun County, Ga. } \\
\hline GA-CAL-OT-1 & $\begin{array}{l}\text { Sowega Minerals, } \\
\text { J. W. West No. } 1\end{array}$ & 2,305 & 212 & 1,687 & 618 & 1,205 & 482 & 625 & 580 & 215 & 410 & $\begin{array}{l}\text { Sections } \mathrm{F}-\mathrm{F}^{\prime}, \mathrm{H}-\mathrm{H}^{\prime} \\
\text { Top, Triassic, below } \\
\text { mean sea level } \\
\text { (feet): } 4,845\end{array}$ \\
\hline
\end{tabular}

\begin{tabular}{|c|c|c|c|c|c|c|c|c|c|c|c|c|}
\hline \multirow[b]{2}{*}{ GA-CAM-OT-1 } & \multirow[b]{2}{*}{$\begin{array}{l}\text { The California Co., } \\
\text { John A. Buie } \# 1\end{array}$} & \multirow[b]{2}{*}{4,337} & \multicolumn{10}{|c|}{ Camden County, Ga. } \\
\hline & & & 48 & 4,070 & 267 & 3,625 & 445 & 3,315 & 310 & 3,135 & 180 & $\begin{array}{l}\text { Potential waste-storage } \\
\text { section Top, Triassic(?), } \\
\text { below mean sea level } \\
\text { (feet): } 4,609(?)\end{array}$ \\
\hline GA-CAM-OT-2 & $\begin{array}{l}\text { Pan American Petroleum Corp., } \\
\# 1-C \text { Union Camp }\end{array}$ & 4,283 & 90 & 3,973 & 310 & 3,693 & 280 & 3,313 & 380 & 2,818 & 495 & $\begin{array}{l}\text { Section } C-C^{\prime} \\
\text { Top, Triassic, below mean } \\
\text { sea level (feet): } 4,505\end{array}$ \\
\hline \multirow[t]{2}{*}{ GA-CAM-OT-3 } & $\begin{array}{l}\text { Pan American Petroleum } \\
\text { Corp., } \# 1-B \text { Union Camp }\end{array}$ & 4,294 & 53 & 3,977 & 317 & 3,692 & 285 & 3,324 & 368 & 2,842 & 482 & $\begin{array}{l}\text { Top, Triassic, below mean } \\
\text { sea level (feet): } 4,517\end{array}$ \\
\hline & & & \multicolumn{10}{|c|}{ Charlton County, Ga. } \\
\hline GA-CHR-OT-1 & $\begin{array}{l}\text { South Penn Oil Co. } \\
\quad 1 \text { O.C. Mizell }\end{array}$ & 4,194 & 130 & 3,884 & 310 & 3,574 & 310 & 3,194 & 380 & 2,744 & 450 & $\begin{array}{l}\text { Top, pre-Cretaceous } \\
\text { crystalline rock, below } \\
\text { mean sea level } \\
\text { (feet): } \mathbf{4 , 4 5 4}\end{array}$ \\
\hline
\end{tabular}

\begin{tabular}{|c|c|c|c|c|c|c|c|c|c|c|c|c|}
\hline \multirow[b]{2}{*}{ GA-CHA-T-3 } & \multirow[b]{2}{*}{ Savannah Ports Authority } & \multirow[b]{2}{*}{ - } & \multicolumn{10}{|c|}{ Chatham County, Ga. } \\
\hline & & & - & 2,945 & $>475$ & 2,600 & 345 & 2,140 & 460 & 1,720 & 420 & Sections $\mathbf{A}-\mathbf{A}^{\prime}, \mathrm{B}-\mathrm{B}^{\prime}, \mathrm{C}-\mathrm{C}^{\prime}$ \\
\hline & & & \multicolumn{10}{|c|}{ Clinch County, Ga. } \\
\hline Ga-CLI-OT-1 & $\begin{array}{l}\text { Wiley P. Ballard, Jr., } \\
\text { Timber Products Co. \#1-A }\end{array}$ & 3,557 & 278 & 3,145 & 412 & 2,735 & 410 & 2,497 & 238 & 2,323 & 174 & $\begin{array}{l}\text { Top, Triassic(?), below } \\
\text { mean sea level } \\
\text { (feet): } 3,945\end{array}$ \\
\hline GA-CLI-OT-2 & $\begin{array}{l}\text { Luke Grace Drilling Co., } \\
* 1 \text { Lem Griffis }\end{array}$ & 3,496 & 175 & 3,353 & 143 & 2,986 & 367 & 2,786 & 200 & 2,701 & 85 & $\begin{array}{l}\text { Top, Paleozoic, below } \\
\text { mean sea level } \\
\text { (feet): } 3.724\end{array}$ \\
\hline GA-CLI-OT-3 & $\begin{array}{l}\text { Hunt Oil Co., } \\
\text { Alice Musgrove } \# 1\end{array}$ & 3,492 & 140 & 3,228 & 264 & 2,832 & 396 & 2,712 & 120 & 2,672 & 40 & $\begin{array}{l}\text { Top, Paleozoic, below } \\
\text { mean sea level } \\
\text { (feet): } 3,775\end{array}$ \\
\hline GA-CLI-OT-4 & $\begin{array}{l}\text { Hunt Oil Co. } \\
\text { Alice Musgrove } * 2\end{array}$ & - & - & - & - & 2,899 & $>340$ & 2,799 & 100 & 2,761 & 38 & \\
\hline \multirow[t]{2}{*}{ GA-CLI-OT-5 } & $\begin{array}{l}\text { Sun Oil Co. } \\
\text { W. J. Barlow *1 }\end{array}$ & 3,453 & 148 & 3,183 & 270 & 2,778 & 405 & 2,683 & 95 & abs. & - & $\begin{array}{l}\text { Section D-D' } \\
\text { Top, Paleozoic, below } \\
\text { mean sea level } \\
\text { (feet): } 3,658\end{array}$ \\
\hline & & & \multicolumn{10}{|c|}{ Coffee County, Ga. } \\
\hline GA-COF-OT-1 & Carpenter Oil Co., & 3,186 & $>66$ & 2,898 & 288 & 2,401 & 497 & 1,956 & 445 & 1,526 & 430 & \\
\hline GA-COF-OT-2 & $\begin{array}{l}\text { Carpenter Oil Co., } \\
\text { Terrell Thurman } \# 1\end{array}$ & 3,192 & 225 & 2894 & 298 & 2,397 & 497 & 1,952 & $\mathbf{4 4 5}$ & 1,534 & 418 & $\begin{array}{l}\text { Top, Triassic(?), below } \\
\text { mean sea level } \\
\text { (feet): } 3,792\end{array}$ \\
\hline GA-COF-OT-3 & $\begin{array}{l}\text { Carpenter Oil Co., } \\
\text { J. H. Knight } \# 1\end{array}$ & 3,185 & 182 & 2,895 & 290 & 2,400 & 495 & 1,955 & 445 & 1,525 & 430 & $\begin{array}{l}\text { Top, Triassic(?), below } \\
\text { mean sea level } \\
\text { (feet): } 3,805\end{array}$ \\
\hline \multirow[t]{2}{*}{ GA-COF-OT-8 } & $\begin{array}{l}\text { Chevron Oil Co., } \\
\text { Oveda Fussell }\end{array}$ & 3,277 & 148 & 2,760 & 517 & 2,345 & 415 & 1,880 & 465 & 1,485 & 395 & $\begin{array}{l}\text { Section } D_{-1}^{\prime} \\
\text { Top Triassic(?), below } \\
\text { mean sea level } \\
\text { (feet): } 4,005\end{array}$ \\
\hline & & & \multicolumn{10}{|c|}{ Colquitt County, Ga. } \\
\hline GA-COQ-OT-1 & $\begin{array}{l}\text { R. T. Adams, } \\
\text { D. G. Arrington } \# 1\end{array}$ & 3,040 & 200 & 2,560 & 480 & 2,135 & 425 & 1,632 & 503 & 1,410 & 222 & $\begin{array}{l}\text { Section F-F' } \\
\text { Potential waste-storage } \\
\text { section }\end{array}$ \\
\hline
\end{tabular}


TABLE 6.-Well number, name, location, elevation, depth, and stratigraphic

\begin{tabular}{|c|c|c|c|c|c|c|c|c|c|c|c|c|}
\hline \multirow[b]{2}{*}{ Well number } & \multirow[b]{2}{*}{ Well name } & \multicolumn{2}{|c|}{$\begin{array}{c}\text { Coordinate } \\
\text { location }\end{array}$} & \multirow[b]{2}{*}{$\begin{array}{c}\text { - Elevation of } \\
\text { measuring } \\
\text { point }(\mathrm{ft})\end{array}$} & \multirow[b]{2}{*}{$\begin{array}{l}\text { Elevation } \\
\text { of ground } \\
\text { level }(\mathrm{ft})\end{array}$} & \multirow[b]{2}{*}{$\begin{array}{l}\text { Total depth } \\
\text { (ft) }\end{array}$} & \multicolumn{2}{|c|}{ Unit $\mathbf{H}(?)$} & \multicolumn{2}{|c|}{ Unit $G(?)$} & \multicolumn{2}{|c|}{ Unit F } \\
\hline & & Lat. & Long. & & & & $\begin{array}{l}\text { Depth to } \\
\text { top below } \\
\text { mean sea } \\
\text { level (ft) }\end{array}$ & $\begin{array}{c}\text { Thickness } \\
\text { (ft) }\end{array}$ & $\begin{array}{l}\text { Depth to } \\
\text { top below } \\
\text { mean sea } \\
\text { level (ft) }\end{array}$ & $\begin{array}{l}\text { Thickness } \\
\text { (ft) }\end{array}$ & $\begin{array}{l}\text { Depth to } \\
\text { top below } \\
\text { mean sea } \\
\text { level (ft) }\end{array}$ & $\underset{(\mathrm{ft})}{\text { Thickness }}$ \\
\hline & & \multicolumn{11}{|c|}{ Crisp County, Ga. } \\
\hline GA-CRP-OT-1 & $\begin{array}{l}\text { Kerr-McGee, } \\
\text { Cecil Pate * } 1\end{array}$ & $31^{\circ} 49^{\prime} 36^{\prime \prime}$ & $83^{\circ} 46^{\prime} 12^{\prime \prime}$ & 370 & 364 & 5,008 & abs. & - & $3,385(?)$ & 465 & 2,710 & 675 \\
\hline
\end{tabular}

\begin{tabular}{|c|c|c|c|c|c|c|c|c|c|c|c|c|}
\hline \multirow[b]{2}{*}{ GA-DE-OT-1 } & \multirow{3}{*}{$\begin{array}{l}\text { Renwar Oil Corp., } \\
\text { G. E. Dollar } \# 1 \\
\text { Hunt Oil Coo, } \\
\text { Metcalf *i }\end{array}$} & \multicolumn{11}{|c|}{ Decatur County, Ga. } \\
\hline & & $30^{\circ} 59^{\prime} 2 T^{\prime}$ & $84^{\circ} 29^{\prime} 33^{\prime \prime}$ & 129 & 124 & 4,990 & - & - & $4,596(?)$ & $>265$ & 3,383 & 1,213 \\
\hline GA-DE-0T-2 & & $30^{\circ} 48^{\prime} 40^{\circ}$ & $84^{\circ} 39^{1} 13^{\prime \prime}$ & 104 & - & 6,152 & $5,66 \times ?)$ & $>382$ & $4,906(?)$ & 760 & 3,446 & 1,460 \\
\hline GA-DE-OT-4 & Calvary Development Co., & $30^{\circ} 42^{\prime} 29^{\prime}$ & $84^{\circ} 23^{\prime} 17$ & 278 & 270 & 4,195 & - & - & - & - & 3,604 & $>313$ \\
\hline GA-DE-OT-5 & $\begin{array}{l}\text { D. E. Hughes, } \\
\text { Martin } \% 1\end{array}$ & $30^{\circ} 58^{\prime} 43^{\prime}$ & $84^{\circ} 31^{\prime} 63^{\prime \prime}$ & 132 & - & 3,717 & - & - & - & 一 & 3,298 & $>287$ \\
\hline GA-DOD-OT-1 & $\begin{array}{c}\text { Atlanta Gas Light, } \\
\text { B \& L Farms }\end{array}$ & $32^{\circ} 15^{\prime} 30^{\prime \prime}$ & $83^{\circ} 17^{\prime} 25^{\prime \prime}$ & 310 & 302 & 4,529 & abs. & - & abs. & - & 2,030 & 430 \\
\hline
\end{tabular}

\begin{tabular}{|c|c|c|c|c|c|c|c|c|c|c|c|}
\hline & & & & & Dooly C & y, Ga. & & & & & \\
\hline 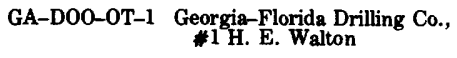 & $32^{\circ} 02^{\prime} 30^{\circ}$ & $83^{\circ} 39^{\prime} 00$ & 446 & 442 & 3,748 & abs. & - & abs. & - & 2,442 & 624 \\
\hline
\end{tabular}

\begin{tabular}{|c|c|c|c|c|c|c|c|c|c|c|c|c|}
\hline \multirow{3}{*}{$\begin{array}{l}\text { GA-DOG-OT-1 } \\
\text { GA-DOG-OT-2 }\end{array}$} & \multirow{3}{*}{$\begin{array}{l}\text { J. R. Sealy, } \\
\text { Reynolds \#1 } \\
\text { J. R. Sealy, } \\
\text { *2 Reynolds Lumber Co. }\end{array}$} & \multicolumn{11}{|c|}{ Dougherty County, Ga. } \\
\hline & & $31^{\circ} 34^{\prime} 08^{\prime \prime}$ & $84^{\circ} 15^{\prime} 1 Z^{\prime}$ & 209 & 199 & 5,012 & 4,531 & $>272$ & $3,841(?)$ & 690 & 2,756 & 1,085 \\
\hline & & $31^{\circ} 27^{\prime} 08^{\prime \prime}$ & $84^{\circ} 21^{\prime} 21^{\prime \prime}$ & 187 & 177 & 5,255 & 4,753 & $>315$ & 4,013 & 740 & 2,803 & 1,210 \\
\hline & & \multicolumn{11}{|c|}{ Early County, Ga. } \\
\hline GA-EA-OT-1 & $\begin{array}{l}\text { Mont-Warren et al, } \\
\text { A. C. Chandler } \# 1\end{array}$ & $31^{\circ} 10^{\prime} 18^{\prime \prime}$ & $85^{\circ} 04^{\prime} 40^{\prime \prime}$ & 187 & 182 & 7,320 & $5,483(?)$ & 915 & $4,513(?)$ & 970 & 2,953 & 1,560 \\
\hline \multirow[t]{2}{*}{ GA-EA-OT_-3 } & $\begin{array}{l}\text { Harris Anderson \& Roy } \\
\text { J. Anderson, *2 Great } \\
\text { Northern Paper Co. }\end{array}$ & $31^{\circ} 10^{\prime} 20^{\prime \prime}$ & $85^{\circ} 04^{\prime} 5 Z^{\prime}$ & 195 & 182 & 7,346 & $5,475(?)$ & 970 & $4,510 ?$ ?) & 965 & 2,955 & 1,555 \\
\hline & & \multicolumn{11}{|c|}{ Echols County, Ga. } \\
\hline GA-EC-OT-3 & $\begin{array}{l}\text { Hunt Oil Co., } \\
\text { Superior Pine Products \#3 }\end{array}$ & $30^{\circ} 36^{\prime} 58^{\prime \prime}$ & $82^{\circ} 46^{\prime} 58^{\prime \prime}$ & 144 & 134 & 4,001 & abs. & - & abs. & - & 3,466 & 45 \\
\hline GA-EC-0T-4 & $\begin{array}{l}\text { Hunt Oil Co., } \\
\text { Superior Pine Products } * 4\end{array}$ & $30^{\circ} 44^{\prime} 12^{\prime \prime}$ & $82^{2} 55^{\prime} 23^{\prime \prime}$ & 157 & 147 & 3,913 & abs. & - & abs. & - & 3,437 & 317 \\
\hline GA-EC-OT-5 & $\begin{array}{l}\text { Humble Oil Co. } \\
\text { Bennett and Langdale } \# 1\end{array}$ & $30^{\circ} 45^{\prime} 29^{\prime \prime}$ & $82^{\circ} 54^{\prime} 36^{\prime \prime}$ & 181 & 171 & 4,185 & abs. & - & abs. & - & 3,554 & 385 \\
\hline
\end{tabular}


data for the 88 wells that make up the key-well network - Continued

\begin{tabular}{|c|c|c|c|c|c|c|c|c|c|c|c|c|}
\hline \multirow[b]{2}{*}{ Well number } & \multirow[b]{2}{*}{ Well name } & \multicolumn{2}{|c|}{ Unit $\mathbf{E}$} & \multicolumn{2}{|c|}{ Unit D } & \multicolumn{2}{|c|}{ Unit C } & \multicolumn{2}{|c|}{ Unit B } & \multicolumn{2}{|c|}{ Unit $\mathbf{A}$} & \multirow[b]{2}{*}{ Remarks } \\
\hline & & $\begin{array}{l}\text { Depth to } \\
\text { top below } \\
\text { mean sea } \\
\text { level (ft) }\end{array}$ & $\begin{array}{c}\text { Thickness } \\
\text { (ft) }\end{array}$ & $\begin{array}{l}\text { Depth to } \\
\text { top below } \\
\text { mean sea } \\
\text { level (ft) }\end{array}$ & $\begin{array}{l}\text { Thickness } \\
\text { (ft) }\end{array}$ & $\begin{array}{l}\text { Depth to } \\
\text { top below } \\
\text { mean sea } \\
\text { level (ft) }\end{array}$ & $\begin{array}{c}\text { Thickness } \\
\text { (ft) }\end{array}$ & $\begin{array}{l}\text { Depth to } \\
\text { top below } \\
\text { mean sea } \\
\text { level (ft) }\end{array}$ & $\begin{array}{l}\text { Thickness } \\
\text { (ft) }\end{array}$ & $\begin{array}{l}\text { Depth to } \\
\text { top below } \\
\text { mean sea } \\
\text { level (ft) }\end{array}$ & $\begin{array}{l}\text { Thickness } \\
\text { (ft) }\end{array}$ & \\
\hline & & & \multicolumn{10}{|c|}{ Crisp County, Ga. } \\
\hline \multirow[t]{2}{*}{ GA-CRP-OT-1 } & $\begin{array}{l}\text { Kerr-McGee, } \\
\text { Cecil Pate } * 1\end{array}$ & 2,630 & 80 & 2,005 & 625 & 1,460 & 545 & 950 & 510 & 555 & 395 & $\begin{array}{l}\text { Section } G-G^{\prime} \\
\text { Top, Triassic(?), below } \\
\text { mean sea level } \\
\text { (feet): } 3,850(?)\end{array}$ \\
\hline & & & \multicolumn{10}{|c|}{ Decatur County, Ga. } \\
\hline GA-DE-OT-1 & $\begin{array}{l}\text { Renwar Oil Corp.; } \\
\text { G. E. Dollar }\end{array}$ & 3,098 & 285 & 2,561 & 537 & 2,153 & 408 & 1,641 & 512 & 1,541 & 100 & Section $G-G^{\prime}$ \\
\hline GA-DE-OT-2 & $\begin{array}{l}\text { Hunt Oil Co., } \\
\text { Metcalf } * 1\end{array}$ & 3,156 & 290 & 2,701 & 455 & 2,266 & 435 & 2,001 & 265 & 1,951 & 50 & section $\mathbf{G}-G^{\prime}$ \\
\hline GA-DE-OT-3 & $\begin{array}{l}\text { J. R. Sealy, } \\
\text { 2 Spindle Top }\end{array}$ & 3,073 & 256 & 2,571 & 502 & 2,281 & 290 & 2,087 & 194 & 2,049 & 38 & $\begin{array}{l}\text { Well actually in Seminole } \\
\text { County, Ga. }\end{array}$ \\
\hline GA-DE-OT-4 & Calvary Development Co., & 3,318 & 286 & 2,842 & 476 & 2,404 & 438 & 2,182 & 222 & abs. & - & \\
\hline \multirow[t]{2}{*}{ GA-DE-OT-5 } & $\begin{array}{l}\text { D. E. Hughes, } \\
\text { Martin } \# 1\end{array}$ & 3,060 & 238 & 2,628 & 532 & 2,128 & 400 & 1,610 & 518 & 1,538 & 72 & \\
\hline & & & \multicolumn{10}{|c|}{ Dodge County, Ga. } \\
\hline \multirow[t]{2}{*}{ GA-DOD-OT-1 } & $\begin{array}{l}\text { Atlanta Gas Light, } \\
\text { B \& L Farms \#1 }\end{array}$ & 1,968 & 62 & 1,706 & 262 & 1,500 & 206 & 990 & 510 & 685 & 305 & $\begin{array}{l}\text { Section } \mathbf{E}-\mathbf{E}^{\prime} \\
\text { Top, Triassic(?), below } \\
\text { mean sea level } \\
\text { (feet): } 2,460\end{array}$ \\
\hline & & & \multicolumn{10}{|c|}{ Dooly County, Ga. } \\
\hline GA-DOO-OT-1 & $\begin{array}{l}\text { Georgia-Florida Drilling Co., } \\
\quad 11 \text { H. E. Walton }\end{array}$ & 2,368 & 74 & 1,690 & 678 & 1,168 & 522 & 630 & 538 & 382 & 248 & $\begin{array}{l}\text { Section } \mathbf{G}-\mathbf{G}^{\prime} \\
\text { Top, Triassic, below } \\
\text { mean sea level } \\
\text { (feet): } \mathbf{3 , 0 6 6}\end{array}$ \\
\hline
\end{tabular}

\begin{tabular}{|c|c|c|c|c|c|c|c|c|c|c|c|}
\hline \multirow{3}{*}{$\begin{array}{ll}\text { GA-DOG-OT-1 } & \text { J. R. Sealy, } \\
\text { GA-DOG-OT-2 } & \text { J. R. Realds } \# 1 \\
& \\
& \end{array}$} & & \multicolumn{10}{|c|}{ Dougherty County, Ga. } \\
\hline & 2,611 & 145 & 2,061 & 550 & 1,571 & 490 & 856 & 715 & 571 & 285 & Section G-G' \\
\hline & 2,663 & 140 & 2,108 & 555 & 1,658 & 450 & 968 & 690 & 718 & 250 & $\begin{array}{l}\text { Section } F-F^{\prime} \\
\text { Potential waste-storage } \\
\text { section }\end{array}$ \\
\hline
\end{tabular}

\begin{tabular}{|c|c|c|c|c|c|c|c|c|c|c|c|c|}
\hline \multirow[b]{2}{*}{ GA-EA-OT-1 } & \multirow[b]{2}{*}{$\begin{array}{l}\text { Mont-Warren et al, } \\
\text { A. C. Chandler } \$ 1\end{array}$} & \multirow[b]{2}{*}{2,738} & \multicolumn{10}{|c|}{ Early County, Ga. } \\
\hline & & & 215 & 2,103 & 635 & 1,618 & 485 & 1,173 & 445 & 1,013 & 160 & $\begin{array}{l}\text { Section H-H' } \\
\text { Potential waste-storage } \\
\text { section Top, Paleozoic, } \\
\text { below mean sea level } \\
\text { (feet): } 6,398\end{array}$ \\
\hline GA-EA-OT-2 & $\begin{array}{l}\text { Harris Anderson \& Roy J. } \\
\text { Anderson, } 11 \text { Great } \\
\text { Northern Paper Co. }\end{array}$ & 2,691 & 305 & 2,092 & 599 & 1,611 & 481 & 1,162 & 449 & 1,018 & 144 & $\begin{array}{l}\text { Potential waste-storage } \\
\text { section Top, Paleozoic, } \\
\text { below mean sea level } \\
\text { (feet): } 6,406\end{array}$ \\
\hline GA-EA-OT-3 & $\begin{array}{l}\text { Harris Anderson \& Roy J. } \\
\text { Anderson, *2 Great } \\
\text { Northern Paper Co. }\end{array}$ & 2,242 & 713 & 2,105 & 137 & 1,625 & 480 & 1,177 & 448 & 1,025 & 152 & $\begin{array}{l}\text { Potential waste-storage } \\
\text { section Top, Paleozoic, } \\
\text { below mean sea level } \\
\text { (feet): } 6,445\end{array}$ \\
\hline
\end{tabular}

\begin{tabular}{|c|c|c|c|c|c|c|c|c|c|c|c|c|}
\hline \multirow[b]{2}{*}{ GA-EC-OT-1 } & \multirow[b]{2}{*}{$\begin{array}{l}\text { Hunt Oil Co. } \\
\text { Superior Pine Products } \# 1\end{array}$} & \multirow[b]{2}{*}{3,324} & \multicolumn{10}{|c|}{ Echols County, Ga. } \\
\hline & & & 70 & 3,124 & 200 & 2,646 & 478 & 2,504 & 142 & 2,469 & 35 & $\begin{array}{l}\text { Potential waste-storage } \\
\text { section Top, Paleozoic, } \\
\text { below mean sea level } \\
\text { (feet): } \mathbf{3 , 6 0 4}\end{array}$ \\
\hline GA-EC-OT-2 & $\begin{array}{l}\text { Hunt Oil Co., } \\
\text { Superior Pine Products } \approx 2\end{array}$ & 3,328 & 142 & 3,248 & 80 & 2,798 & 450 & 2,643 & 155 & 2,576 & 67 & $\begin{array}{l}\text { Section F-F' } \\
\text { Top, Paleozoic, below } \\
\text { mean sea level } \\
\text { (feet): } \mathbf{3 , 5 8 8}\end{array}$ \\
\hline GA-EC-OT -3 & $\begin{array}{l}\text { Hunt Oil Co., } \\
\text { Superior Pine Products } \# 3\end{array}$ & 3,271 & 195 & 3,151 & 120 & 2,678 & 473 & 2,526 & 152 & 2,451 & 75 & $\begin{array}{l}\text { Section D-D' } \\
\text { Top, Paleozoic, below } \\
\text { mean sea level } \\
\text { (feet): } \mathbf{3 , 5 1 1}\end{array}$ \\
\hline GA-EC-OT-4 & $\begin{array}{l}\text { Hunt Oil Co, } \\
\text { Superior Pine Products } * 4\end{array}$ & 3,265 & 172 & 3,105 & 160 & 2,668 & 437 & 2,513 & 155 & 2,463 & 50 & $\begin{array}{l}\text { Top, Paleozoic, below } \\
\text { mean sea level } \\
\text { (feet): } 3,754\end{array}$ \\
\hline GA-EC-OT-5 & $\begin{array}{l}\text { Humble Oil Co. } \\
\text { Bennett and Langdale } \# 1\end{array}$ & 3,389 & 165 & 3,164 & 225 & 2,749 & 415 & 2,629 & 120 & abs & - & $\begin{array}{l}\text { Sections D-D', F-F' } \\
\text { Top, Paleozoic, below } \\
\text { mean sea level } \\
\text { (feet): } 3,939\end{array}$ \\
\hline
\end{tabular}


TABLE 6.-Well number, name, location, elevation, depth, and stratigraphic

\begin{tabular}{|c|c|c|c|c|c|c|c|c|c|c|c|c|}
\hline \multirow[b]{2}{*}{ Well number } & \multirow[b]{2}{*}{ Well name } & \multicolumn{2}{|c|}{$\begin{array}{c}\text { Coordinate } \\
\text { location }\end{array}$} & \multirow[b]{2}{*}{$\begin{array}{c}\text { - Elevation of } \\
\text { measuring } \\
\text { point }(\mathrm{ft})\end{array}$} & \multirow[b]{2}{*}{$\begin{array}{l}\text { Elevation } \\
\text { of ground } \\
\text { level (ft) }\end{array}$} & \multirow[b]{2}{*}{$\begin{array}{l}\text { Total depth } \\
\text { (ft) }\end{array}$} & \multicolumn{2}{|c|}{ Unit $\mathbf{H}(?)$} & \multicolumn{2}{|c|}{ Unit $G(?)$} & \multicolumn{2}{|c|}{ Unit $F$} \\
\hline & & Lat. & Long. & & & & $\begin{array}{l}\text { Depth to } \\
\text { top below } \\
\text { mean sea } \\
\text { level (ft) }\end{array}$ & $\begin{array}{c}\text { Thickness } \\
\text { (ft) }\end{array}$ & $\begin{array}{l}\text { Depth to } \\
\text { top below } \\
\text { mean sea } \\
\text { level (ft) }\end{array}$ & $\begin{array}{l}\text { Thickness } \\
\text { (ft) }\end{array}$ & $\begin{array}{l}\text { Depth to } \\
\text { top below } \\
\text { mean sea } \\
\text { level (ft) }\end{array}$ & $\begin{array}{c}\text { Thickness } \\
\text { (ft) }\end{array}$ \\
\hline & & \multicolumn{11}{|c|}{ Glynn County, Ga. } \\
\hline GA-GLY-OT-1 & $\begin{array}{l}\text { Humble State-1, } \\
\text { Union Bag Camp }\end{array}$ & $31^{\circ} 08^{\prime} 20^{\prime \prime}$ & $81^{\circ} 38^{\prime} 20^{\prime \prime}$ & 29 & 14 & 4,633 & abs. & - & abs. & - & 4,481 & 115 \\
\hline GA-GLY-OT-2 & $\begin{array}{l}\text { Humble } * 1, \\
\text { W. C. MeDonald Estate }\end{array}$ & $31^{\circ} 14^{\prime} 4 Z^{\prime \prime}$ & $81^{\circ} 38^{\prime} 01^{\prime \prime}$ & 25 & 15 & 4,747 & abs. & - & abs. & - & 4,553 & 122 \\
\hline GA-GLY-OT-3 & $\begin{array}{l}\text { E. B. LaRue, } \\
* 1 \text { Roy H. Massey }\end{array}$ & $31^{\circ} 06^{\prime} 49^{\prime \prime}$ & $81^{\circ} 32^{\prime} 32^{\prime \prime}$ & 20 & 15 & 4,240 & - & - & - & - & - & - \\
\hline GA-GLY-OT-7 & $\begin{array}{l}\text { Pan Am. Petroleum, } \\
\text { *1 Union Camp }\end{array}$ & $31^{\circ} 22^{\prime} 20^{\circ}$ & $81^{\circ} 33^{\prime} 54^{\prime \prime}$ & 24 & 13 & 4,460 & abs. & - & abs. & - & 4,216 & 85 \\
\hline
\end{tabular}

\begin{tabular}{|c|c|c|c|c|c|c|c|c|c|c|c|c|}
\hline \multirow[b]{2}{*}{ GA-HO-OT-1 } & \multirow[b]{2}{*}{$\begin{array}{l}\text { Tricon Minerals, Inc. } \\
\text { H.B. Gilbert } \neq 1\end{array}$} & \multicolumn{11}{|c|}{ Houston County, Ga. } \\
\hline & & $32^{2} 24^{\prime} 07$ & $83^{\circ} 43^{\prime} 57$ & 371 & 364 & 1,698 & abs. & - & abs. & - & 861 & 464 \\
\hline
\end{tabular}

\begin{tabular}{|c|c|c|c|c|c|c|c|c|c|c|c|c|}
\hline \multirow[b]{2}{*}{ GA-JD-OT-1 } & \multirow[b]{2}{*}{$\begin{array}{l}\text { Chevron Oil Co., } \\
\text { J. L. Sinclair *1 }\end{array}$} & \multicolumn{11}{|c|}{ Jeff Davis County, Ga. } \\
\hline & & $31^{\circ} 46^{\prime} 08^{\prime \prime}$ & $82^{\circ} 44^{\prime} 53^{\prime \prime}$ & 287 & 271 & 4,058 & abs. & - & abs & - & 3,463 & 284 \\
\hline & & \multicolumn{11}{|c|}{ Laurens County, Ga. } \\
\hline GA-LA-OT-1 & $\begin{array}{l}\text { Calapor Mfg. Corp., } \\
\text { Grace McCain } \# 1\end{array}$ & $32^{\circ} 28^{\prime} 40^{\prime \prime}$ & $82^{\circ} 45^{\prime} 33^{\prime \prime}$ & 287 & 280 & 2,547 & abs. & - & abs. & - & 1,703 & 556 \\
\hline
\end{tabular}

\begin{tabular}{|c|c|c|c|c|c|c|c|c|c|c|c|c|}
\hline \multirow[b]{2}{*}{ GA-LI-OT-1 } & \multirow[b]{2}{*}{$\begin{array}{l}\text { E. B. LaRue, } \\
\text { \#1 Jelks-Rogers }\end{array}$} & \multicolumn{11}{|c|}{ Liberty County, Ga. } \\
\hline & & $31^{\circ} 41^{\prime} 31^{n}$ & $81^{\circ} 20^{\prime} 54^{\prime \prime}$ & 26 & 16 & 4,264 & abs. & - & abs. & - & 3.992 & 232 \\
\hline
\end{tabular}

\begin{tabular}{|c|c|c|c|c|c|c|c|c|c|c|c|c|}
\hline \multirow[b]{2}{*}{ GA-LOW-OT-1 } & \multirow[b]{2}{*}{$\begin{array}{l}\text { Hunt Petroleum Co., } \\
\text { \#1 J. T. Stalvey }\end{array}$} & \multicolumn{11}{|c|}{ Lowndes County, Ga. } \\
\hline & & $30^{\circ} 59^{\prime} 25^{\prime \prime}$ & $83^{\circ} 15^{\prime} 08^{\prime \prime}$ & 167 & 157 & 7,200 & abs. & - & abs. & - & 3,483 & 470 \\
\hline GA-LOW-OT-2 & $\begin{array}{l}\text { Hunt Petroleum Corp., } \\
\text { Langsdale } \# 1\end{array}$ & $30^{\circ} 51^{\prime} 25^{\prime \prime}$ & $83^{\circ} 03^{\prime} 23^{\prime \prime}$ & 182 & 171 & 5,060 & abs. & - & abs. & - & 3,498 & 418 \\
\hline GA-LOW-OT-3 & $\begin{array}{l}\text { Hunt Petroleum Corp., } \\
\text { L. P. Shelton well no. 1A }\end{array}$ & $30^{\circ} 50^{\prime} 54^{\prime \prime}$ & $83^{\circ} 11^{\prime} 16^{\prime \prime}$ & 212 & 201 & 5,000 & abs. & - & abs. & - & 3,520 & 468 \\
\hline GA-LOW-OT-4 & $\begin{array}{l}\text { Hunt Petroleum Corp., } \\
\text { Jack Cole } \# .1\end{array}$ & $30^{\circ} 56^{\prime} 12^{\prime \prime}$ & $83^{\circ} 24^{\prime} 23^{\prime \prime}$ & 254 & 243 & 5,200 & abs. & - & abs. & - & 3,488 & 620 \\
\hline GA-LOW-OT-5 & $\begin{array}{l}\text { Hunt Petroleum Corp., } \\
\# 1 \text { E. N. Murray, Jr. }\end{array}$ & $30^{\circ} 54^{\prime} 21^{\prime \prime}$ & $83^{\circ} 16^{\prime} 52^{\prime \prime}$ & 201 & 191 & 5,004 & abs. & - & abs. & - & 3,482 & 705 \\
\hline
\end{tabular}

\begin{tabular}{|c|c|c|c|c|c|c|c|c|c|c|c|}
\hline \multirow[b]{2}{*}{$\begin{array}{l}\text { GA-MIT-0T-1 Stanolind, } \\
\text { J. H. Pullen } \# 1\end{array}$} & \multicolumn{11}{|c|}{ Mitchell County, Ga. } \\
\hline & $31^{\circ} 08^{\prime} 28^{\prime \prime}$ & $84^{\circ} 04^{\prime} 13^{\prime \prime}$ & 338 & 328 & 7,490 & $5,302(?)$ & 575 & $4,458 ?$ ? & 850 & 3,292 & 1,160 \\
\hline
\end{tabular}

\begin{tabular}{|c|c|c|c|c|c|c|c|c|c|c|c|c|}
\hline \multirow[b]{2}{*}{ GA-MO-OT-2 } & \multirow[b]{2}{*}{$\begin{array}{l}\text { J. E. Weatherford, } \\
\text { Lonnie Wilkes } * 1\end{array}$} & \multicolumn{11}{|c|}{ Montgomery County, Ga. } \\
\hline & & $32^{\circ} 13^{\prime} 01^{\prime \prime}$ & $82^{\prime 2} 28^{\prime} 4 T^{\prime}$ & 293 & 283 & 3,424 & abs. & - & abs. & - & 2,562 & 540 \\
\hline & & \multicolumn{11}{|c|}{ Pierce County, Ga. } \\
\hline GA-PI-OT-1 & $\begin{array}{l}\text { W. B. Hinton-Donald Clark, } \\
\text { Adams MeCaskill } \# 1\end{array}$ & $31^{\circ} 26^{\prime} 30^{\circ}$ & $82^{\circ} 03^{\prime} 40^{\circ}$ & 75 & 75 & 4,354 & abs. & - & abs. & - & abs. & - \\
\hline GA-PI-OT-2 & $\begin{array}{l}\text { Pan American, } \\
\text { Adams-MeCaskill } * 1\end{array}$ & $31^{\circ} 23^{\prime} 47$ & $82^{\circ} 04^{\prime} 16^{\prime \prime}$ & 82 & 75 & 4,378 & abs. & - & abs. & - & abs. & - \\
\hline
\end{tabular}


data for the 88 wells that make up the key-well network-Continued

\begin{tabular}{|c|c|c|c|c|c|c|c|c|c|c|c|c|}
\hline \multirow[b]{2}{*}{ Well number } & \multirow[b]{2}{*}{ Well name } & \multicolumn{2}{|c|}{ Unit $E$} & \multicolumn{2}{|c|}{ Unit $\mathbf{D}$} & \multicolumn{2}{|c|}{ Unit C } & \multicolumn{2}{|c|}{ Unit B } & \multicolumn{2}{|c|}{ Unit A } & \multirow[b]{2}{*}{ Remarks } \\
\hline & & $\begin{array}{l}\text { Depth to } \\
\text { top below } \\
\text { mean sea } \\
\text { level }(\mathrm{ft})\end{array}$ & $\begin{array}{c}\text { Thickness } \\
\text { (ft) }\end{array}$ & $\begin{array}{l}\text { Depth to } \\
\text { top below } \\
\text { mean sea } \\
\text { level (ft) }\end{array}$ & $\underset{(\mathrm{ft})}{\text { Thickness }}$ & $\begin{array}{l}\text { Depth to } \\
\text { top below } \\
\text { mean sea } \\
\text { level }(\mathrm{ft})\end{array}$ & $\begin{array}{l}\text { Thickness } \\
\text { (ft) }\end{array}$ & $\begin{array}{l}\text { Depth to } \\
\text { top below } \\
\text { mean sea } \\
\text { level (ft) }\end{array}$ & $\begin{array}{l}\text { Thickness } \\
\text { (ft) }\end{array}$ & $\begin{array}{l}\text { Depth to } \\
\text { top below } \\
\text { mean sea } \\
\text { level (ft) }\end{array}$ & $\begin{array}{l}\text { Thickness } \\
\text { (ft) }\end{array}$ & \\
\hline & & & \multicolumn{10}{|c|}{ Glynn County, Ga. } \\
\hline GA-GLY-OT-1 & $\begin{array}{l}\text { Humble State-1, } \\
\text { Union Bag Camp }\end{array}$ & 4,426 & 55 & 4,201 & 225 & 3,766 & 435 & 3,376 & 390 & 2,659 & 717 & $\begin{array}{l}\text { Section } \mathrm{C}-\mathrm{C}^{\prime} \\
\text { Top, pre-Cretaceous } \\
\text { crystalline rock, } \\
\text { below mean sea level } \\
\text { (feet): } 4.596\end{array}$ \\
\hline GA-GLY-OT-2 & $\begin{array}{l}\text { Humble } \# 1 \text {, } \\
\text { W. C. McDonald Estate }\end{array}$ & 4,475 & 78 & 4,080 & 395 & 3,665 & 415 & $\mathbf{3 , 3 4 5}$ & 320 & 2,495 & 850 & $\begin{array}{l}\text { Sections } \mathbf{C}-C^{\prime}, E-E^{\prime} \\
\text { Potential waste-storage sect } \\
\text { Top, pre-Cretaceous } \\
\text { crystalline rock, } \\
\text { below mean sea level } \\
\text { (feet): } \mathbf{4 , 6 7 5}\end{array}$ \\
\hline GA-GLY-OT-3 & $\begin{array}{l}\text { E. B. LaRue, } \\
\text { *1 Roy H. Massey }\end{array}$ & - & - & 4,128 & $>92$ & 3,750 & 378 & 3,465 & 285 & 2,600 & 865 & \\
\hline \multirow[t]{2}{*}{ GA-GLY-OT-7 } & $\begin{array}{l}\text { Pan Am. Petroleum, } \\
\text { \#1 Union Camp }\end{array}$ & 4,126 & 90 & 3,906 & 220 & 3,496 & 410 & 3,271 & 225 & 2,346 & 925 & $\begin{array}{l}\text { Section C-C' } \\
\text { Potential waste-storage sect } \\
\text { Top, pre-Cretaceous } \\
\text { crystalline rock, } \\
\text { below mean sea level } \\
\text { (feet): } 4,301\end{array}$ \\
\hline & & & \multicolumn{10}{|c|}{ Houston County, Ga. } \\
\hline \multirow[t]{2}{*}{ GA-HO-OT-1 } & $\begin{array}{l}\text { Tricon Minerals, Inc. } \\
\text { H. B. Gilbert No. } 1\end{array}$ & abs. & - & 599 & 262 & 424 & 175 & 159 & 265 & +181 & 340 & $\begin{array}{l}\text { Section E-E' } \\
\text { Top, pre-Cretaceous } \\
\text { crystalline rock, } \\
\text { below mean sea level } \\
\text { (feet): } 1,325\end{array}$ \\
\hline & & & \multicolumn{10}{|c|}{ Jeff Davis County, Ga. } \\
\hline \multirow[t]{2}{*}{ GA-JD-0T-1 } & $\begin{array}{l}\text { Chevron Oil Co., } \\
\text { J. L. Sinclair } \# 1\end{array}$ & 3,303 & 160 & 2,843 & 460 & 2,337 & 506 & 1,925 & 412 & 1,519 & 406 & $\begin{array}{l}\text { Section D-D' } \\
\text { Top, Triassic(?), } \\
\text { below mean sea level } \\
\text { (feet): } 3,747\end{array}$ \\
\hline & & & \multicolumn{10}{|c|}{ Laurens County, Ga. } \\
\hline \multirow[t]{2}{*}{ GA-LA-OT-1 } & $\begin{array}{l}\text { Calapor Mfg. Corp.; } \\
\text { Grace MeCam }\end{array}$ & 1,573 & 130 & 1,293 & 280 & 1,128 & 165 & 903 & 225 & 673 & 230 & $\begin{array}{l}\text { Section D-D' } \\
\text { Top, Triassic(?), } \\
\text { below mean sea level } \\
\text { (feet): } \mathbf{2 , 2 5 9}\end{array}$ \\
\hline & & & \multicolumn{10}{|c|}{ Liberty County, Ga. } \\
\hline \multirow[t]{2}{*}{ GA-LI-OT-1 } & $\begin{array}{l}\text { E. B. LaRue, } \\
\text { \#1 Jelks-Rogers }\end{array}$ & 3,854 & 138 & 3,444 & 10 & 3,006 & 438 & 2,694 & 312 & 2,209 & 485 & $\begin{array}{l}\text { Sections A-A', C-C' } \\
\text { Top, Triassic(?), below } \\
\text { mean sea level } \\
\text { (feet): } 4,224(?)\end{array}$ \\
\hline & & & \multicolumn{10}{|c|}{ Lowndes County, Ga. } \\
\hline GA-LOW-OT-1 & $\begin{array}{l}\text { Hunt Petroleum Co., } \\
\text { \#1 J. T. Stalvey }\end{array}$ & 3,275 & 208 & 2,983 & 342 & 2,693 & 240 & 2,523 & 170 & abs. & - & $\begin{array}{l}\text { Section F-F"' } \\
\text { Top, Paleozoic, below } \\
\text { mean sea level } \\
\text { (feet): } 3,953\end{array}$ \\
\hline GA-LOW-OT-2 & $\begin{array}{l}\text { Hunt Petroleum Corp., } \\
\text { Langsdale } * 1\end{array}$ & 3,348 & 150 & 3,053 & 295 & 2,768 & 285 & 2,520 & 248 & abs. & - & $\begin{array}{l}\text { Section } \bar{F}-\bar{F}^{\prime} \\
\text { Top, Paleozoic, below } \\
\text { mean sea level } \\
\text { (feet): } \mathbf{3 . 9 1 6}\end{array}$ \\
\hline GA-LOW-OT_3 & $\begin{array}{l}\text { Hunt Petroleum Corp., } \\
\text { L. P. Shelton well no. 1A }\end{array}$ & $3, \mathbf{3 4 3}$ & 177 & 3,028 & 315 & 2,758 & 270 & 2,473 & 285 & abs. & - & $\begin{array}{l}\text { Top Paleozoic, below } \\
\text { mean sea level } \\
\text { (feet): } 3,988\end{array}$ \\
\hline GA-LOW-OT-4 & $\begin{array}{l}\text { Hunt Petroleum Corp., } \\
\text { Jack Cole No. } 1\end{array}$ & 3,236 & 252 & 2,896 & 340 & 2,636 & 260 & 2,316 & 320 & abs. & - & $\begin{array}{l}\text { Top, Paleozoic, below } \\
\text { mean sea level } \\
\text { (feet): } 4,108\end{array}$ \\
\hline \multirow[t]{2}{*}{ GA-LOW-OT-5 } & $\begin{array}{l}\text { Hunt Petroleum Corp, } \\
\quad 1 \text { E. N. Murray, Jr. }\end{array}$ & 3,309 & 173 & 2,979 & 330 & 2,719 & 260 & 2,449 & 270 & abs. & - & $\begin{array}{l}\text { Potential waste-storage } \\
\text { section Top, Paleozoic, } \\
\text { below mean sea level } \\
\text { (feet): } 4,187\end{array}$ \\
\hline & & & \multicolumn{10}{|c|}{ Mitchell County, Ga. } \\
\hline \multirow[t]{2}{*}{ GA-MIT-OT-1 } & $\begin{array}{l}\text { Stanolind, } \\
\text { J. H. Pullen *1 }\end{array}$ & 3,052 & 240 & 2,552 & 500 & 2,102 & 450 & 1,587 & 515 & 1,357 & 230 & $\begin{array}{l}\text { Sections } F-F^{\prime}, G-G^{\prime} \\
\text { Potential waste-storage } \\
\text { section Top, Triassic (?), } \\
\text { below mean sea level } \\
\text { (feet): } 5,877(?)\end{array}$ \\
\hline & & & \multicolumn{10}{|c|}{ Montgomery County, Ga. } \\
\hline \multirow[t]{2}{*}{ GA-MO-OT-2 } & $\begin{array}{l}\text { J. E. Weatherford, } \\
\text { Lonnie Wilkes } * 1\end{array}$ & 2,361 & 201 & 2,082 & 279 & 1,861 & 221 & 1,517 & 344 & 1,207 & 310 & $\begin{array}{l}\text { Top, Triassic(?), below } \\
\text { mean sea level } \\
\text { (feet): } 3,102\end{array}$ \\
\hline & & & \multicolumn{10}{|c|}{ Pierce County, Ga. } \\
\hline GA-PI-OT-1 & $\begin{array}{l}\text { W. B. Hinton-Donald Clark, } \\
\text { Adams MeCaskill } 11\end{array}$ & 4,160 & 110 & 3,812 & 348 & 3,510 & 302 & 3,070 & 440 & 2,670 & 400 & $\begin{array}{l}\text { Section E-E' } \\
\text { Top, pre-Cretaceous } \\
\text { crystalline rock, below } \\
\text { mean sea level } \\
\text { (feet): } 4,270\end{array}$ \\
\hline GA-PI-OT-2 & $\begin{array}{l}\text { Pan American, } \\
\text { Adams-MeCaskill \#1 }\end{array}$ & 4,164 & 102 & 3,874 & 290 & 3,538 & 336 & 3,068 & 470 & 2,638 & 430 & $\begin{array}{l}\text { Top, pre-Cretaceous } \\
\text { crystalline rock, below } \\
\text { mean sea level } \\
\text { (feet): } 4,266\end{array}$ \\
\hline
\end{tabular}


data for the 88 wells that make up the key-well network-Continued

\begin{tabular}{|c|c|c|c|c|c|c|c|c|c|c|c|c|}
\hline \multirow[b]{2}{*}{ Well number } & \multirow[b]{2}{*}{ Well name } & \multicolumn{2}{|c|}{ Unit $\mathbf{E}$} & \multicolumn{2}{|c|}{ Unit $D$} & \multicolumn{2}{|c|}{ Unit $\mathbf{C}$} & \multicolumn{2}{|c|}{ Unit B } & \multicolumn{2}{|c|}{ Unit A } & \multirow[b]{2}{*}{ Remarks } \\
\hline & & $\begin{array}{l}\text { Depth to } \\
\text { top below } \\
\text { mean sea } \\
\text { level (ft) }\end{array}$ & $\begin{array}{c}\text { Thickness } \\
\text { (ft) }\end{array}$ & $\begin{array}{l}\text { Depth to } \\
\text { top below } \\
\text { mean sea } \\
\text { level (ft) }\end{array}$ & $\begin{array}{l}\text { Thickness } \\
\text { (ft) }\end{array}$ & $\begin{array}{l}\text { Depth to } \\
\text { top below } \\
\text { mean sea } \\
\text { level (ft) }\end{array}$ & $\begin{array}{l}\text { Thickness } \\
\text { (ft) }\end{array}$ & $\begin{array}{l}\text { Depth to } \\
\text { top below } \\
\text { mean sea } \\
\text { level (ft) }\end{array}$ & $\begin{array}{c}\text { Thiekness } \\
\text { (ft) }\end{array}$ & $\begin{array}{l}\text { Depth to } \\
\text { top below } \\
\text { mean sea } \\
\text { level (ft) }\end{array}$ & $\begin{array}{l}\text { Thickness } \\
\text { (ft) }\end{array}$ & \\
\hline & & & \multicolumn{10}{|c|}{ Pulaski County, Ga. } \\
\hline GA-PU_OT-3 & $\begin{array}{l}\text { Atlanta Gas Light Co., } \\
* 1 \text { Griffth }\end{array}$ & 429 & 225 & 189 & 240 & - & 105 & - & - & +71 & - & $\begin{array}{l}\text { Sections E-E', G-G' } \\
\text { Top, Triassic(?), below } \\
\text { mean sea level } \\
\text { (feet): } 2,007 \\
\text { No data available for } \\
\text { Units A thru E } \\
\text { Top, Triassic(?), below } \\
\text { mean sea level } \\
\text { (feet): } 1,883\end{array}$ \\
\hline \multicolumn{13}{|c|}{ Screven County, Ga. } \\
\hline GA-SCR-OT-1 & $\begin{array}{l}\text { Boenwell Drilling Co., } \\
\text { McCain-Pryor } * 1\end{array}$ & abs. & - & 1,578 & 475 & 1,475 & 103 & 1,223 & 252 & 773 & 450 & $\begin{array}{l}\text { Sections B-B', C-C' } \\
\text { Top, pre-Cretaceous } \\
\text { crystalline rock, below } \\
\text { mean sea level } \\
\text { (feet): } 2,527\end{array}$ \\
\hline \multicolumn{13}{|c|}{ Seminole County, Ga. } \\
\hline GA-SE-OT-1 & $\begin{array}{l}\text { Humble Oil and Refining Co., } \\
\# 1 \text { J. R. Sealy }\end{array}$ & 3,024 & 320 & 2,554 & 470 & 2,234 & 320 & 1,964 & 270 & 1,944 & 20 & $\begin{array}{l}\text { Site now under water- } \\
\text { Jim Woodruff Reservoir }\end{array}$ \\
\hline GA-SE-OT-2 & $\begin{array}{l}\text { Mont Warren, } \\
\text { Grady Bell } \# 1\end{array}$ & 2,961 & 335 & 2,478 & 483 & 2,220 & 258 & 1,786 & 434 & 1,726 & 60 & \\
\hline GA-SE-OT-3 & $\begin{array}{l}\text { J. R. Sealy } \\
* 5 \text { Spindle Top Ida }\end{array}$ & 3,028 & 294 & 2,612 & 416 & 2,270 & 342 & 2,066 & 204 & 2,024 & 42 & $\begin{array}{l}\text { Section H-H' } \\
\text { Potential waste-storage } \\
\text { section }\end{array}$ \\
\hline GA-SE-OT-4 & $\begin{array}{l}\text { Mont Warren } \\
\text { Emily Harlow }\end{array}$ & 2,908 & 210 & 2,323 & 580 & 1,933 & 390 & 1,363 & 570 & 1,283 & 80 & Section $\mathbf{H}-\mathbf{H}^{\prime}$ \\
\hline GA-SE-OT-6 & $\begin{array}{l}\text { S. C. Dunlap } \\
\text { Saunders Co., } \# 1\end{array}$ & 2,970 & 280 & 2,455 & 515 & 2,150 & 305 & 1,820 & 330 & 1,735 & 85 & $\begin{array}{l}\text { Section } \mathbf{H}-\mathbf{H}^{\prime} \\
\text { Potential waste-storage } \\
\text { section } \\
\text { Top, Triassic(?), below } \\
\text { mean sea level } \\
\text { (feet): } 6,915(?)\end{array}$ \\
\hline \multicolumn{13}{|c|}{ Stewart County, Ga. } \\
\hline GA-ST-OT-1 & $\begin{array}{l}\text { Heinze-Spanel, } \\
\text { W. C. Bradley No. } 1\end{array}$ & 1,332 & 150 & 742 & 590 & 297 & 445 & +28 & 325 & $358 t$ & $\mathbf{3 3 0}$ & $\begin{array}{l}\text { Section } \mathrm{H}-\mathrm{H}^{\prime} \\
\text { Top, Triassic(?), below } \\
\text { mean sea level } \\
\text { (feet): } \mathbf{2 , 3 1 2}\end{array}$ \\
\hline & & & \multicolumn{10}{|c|}{ Sumter County, Ga. } \\
\hline \multirow[t]{2}{*}{ GA-SU-OT-1 } & $\begin{array}{l}\text { Hill \& Son Drilling Co., } \\
\text { Moore-Martino } 1\end{array}$ & 1,510 & 128 & 978 & 582 & 508 & 470 & 8 & 500 & +332 & 340 & \\
\hline & & & \multicolumn{10}{|c|}{ Telfair County, Ga. } \\
\hline \multirow[t]{2}{*}{ GA-TEL_OT-1 } & \#1 Henry Spurlin & 2,853 & 135 & 2,593 & 260 & 2,258 & 335 & 1,918 & 340 & 1,588 & 330 & $\begin{array}{l}\text { Section } \mathbf{E}-\mathbf{E}^{\prime} \\
\text { Top, Triassic(?), below } \\
\text { mean sea level } \\
\text { (feet): } \mathbf{3 , 5 0 0}\end{array}$ \\
\hline & & & \multicolumn{10}{|c|}{ Thomas County, Ga. } \\
\hline \multirow[t]{2}{*}{ GA-THO-OT-2 } & $\begin{array}{l}\text { Thomas A. Durham, } \\
\text { Irene E. W. Sedgewick \#1A }\end{array}$ & 3,227 & 247 & 2,751 & 476 & 2,456 & 295 & 2,161 & 295 & 2,117 & 44 & $\begin{array}{l}\text { Top, Paleozoic, below } \\
\text { mean sea level } \\
\text { (feet): } 5,471\end{array}$ \\
\hline & & & \multicolumn{10}{|c|}{ Toombe County, Ga. } \\
\hline \multirow[t]{2}{*}{ GA-TO0-0T-1 } & $\begin{array}{l}\text { Tropic Oil and Gas, } \\
\text { Gibson } \# 1\end{array}$ & 2,682 & 160 & 2,422 & 260 & 2,222 & 200 & 1,842 & 380 & 1,502 & 340 & $\begin{array}{l}\text { Top, Triassic(?), below } \\
\text { mean sea level } \\
\text { (feet): } \mathbf{3 , 3 1 2}\end{array}$ \\
\hline & & & \multicolumn{10}{|c|}{ Treutlen County, Ga. } \\
\hline GA-TR-OT-1 & $\begin{array}{l}\text { Barnwell Drilling Co., Inc. } \\
\text { Jim L. Gillis, Sr. } 1\end{array}$ & 1,982 & 150 & 1,707 & 275 & 1,492 & 215 & 1,242 & 250 & 1,022 & 220 & $\begin{array}{l}\text { Top, Triassic(?), below } \\
\text { mean sea level } \\
\text { (feet): } 2,695\end{array}$ \\
\hline \multirow[t]{2}{*}{ GA-TR-OT-2 } & $\begin{array}{l}\text { MeCain and Nicholson, } \\
\text { \#1 Jim Gillis, Sr. }\end{array}$ & 2,131 & 170 & 1,811 & 320 & 1,571 & 240 & 1,321 & 250 & 1,081 & 240 & $\begin{array}{l}\text { Top, pre-Cretaceous } \\
\text { crystalline rock, below } \\
\text { mean sea level } \\
\text { (feet): } \mathbf{2 , 8 1 7}\end{array}$ \\
\hline & & & \multicolumn{10}{|c|}{ Wayne County, Ga. } \\
\hline GA-WAY-OT-1 & $\begin{array}{l}\text { Humble \#1 } \\
\text { Union Bag Camp Paper }\end{array}$ & 3,965 & 202 & 3,607 & 358 & 3,335 & 272 & 2,880 & 455 & 2,405 & 475 & $\begin{array}{l}\text { Section } \mathbf{C - C} \mathbf{C}^{\prime} \\
\text { Top, Triassic, below } \\
\text { mean sea level } \\
\text { (feet): } 4,291(?)\end{array}$ \\
\hline GA-WAY-OT-2 & $\begin{array}{l}\text { California Co., } \\
\text { Brunswick Peninsular Corp. } \# 1\end{array}$ & 4,237 & 152 & 3,812 & 425 & 3,497 & 315 & 3,097 & 400 & 2,587 & 510 & $\begin{array}{l}\text { Section E-E' } \\
\text { Top, pre-Cretaceous } \\
\text { crystalhe rock, below } \\
\text { mean sea level } \\
\text { (feet): } 4,502(?)\end{array}$ \\
\hline GA-WAY-OT-6 & $\begin{array}{l}\text { Hunt Petroleum Corp., } \\
\text { W. K. Davis-Scott and } \\
\text { Mead } \# 1 \text { A }\end{array}$ & 4,196 & 146 & 3,921 & 275 & 3,280 & 641 & 3,008 & 272 & 2,281 & 727 & \\
\hline
\end{tabular}


TABLE 6.-Well number, name, location, elevation, depth, and stratigraphic

\begin{tabular}{|c|c|c|c|c|c|c|c|c|c|c|c|c|}
\hline Well number & Well name & \multicolumn{2}{|c|}{$\begin{array}{c}\text { Coordinate } \\
\text { location }\end{array}$} & $\begin{array}{c}\text { - Elevation of } \\
\text { measuring } \\
\text { point }(\mathrm{t})\end{array}$ & $\begin{array}{l}\text { Elevation } \\
\text { of ground } \\
\text { level }(\boldsymbol{f})\end{array}$ & $\begin{array}{l}\text { Total depth } \\
\text { (t) }\end{array}$ & \multicolumn{2}{|c|}{ Unit $H(?)$} & \multicolumn{2}{|c|}{ Unit $\mathbf{G}(?)$} & \multicolumn{2}{|c|}{ Unit $F$} \\
\hline & & \multicolumn{11}{|c|}{ Wheeler County, Ga. } \\
\hline GA-WH-OT-1 & $\begin{array}{l}\text { T. R. Davis \& Assoc, } \\
\text { Jordan Heirs No. i }\end{array}$ & $31^{\circ} 58^{\prime} 47^{\prime \prime}$ & $82^{\circ} 38^{\prime} 48^{\prime \prime}$ & 195 & 185 & 4,010 & abs. & - & abs. & - & 3,070 & 439 \\
\hline GA-WH-OT-3 & $\begin{array}{l}\text { Southern Natural Gas Co., } \\
\text { Ronnie Towns } * 1\end{array}$ & $32^{\circ} 02^{\prime} 3 T^{\prime \prime}$ & $82^{\circ} 38^{\prime} 12^{\circ}$ & 169 & 157 & 4,070 & abs. & - & abs. & - & 3,058 & 598 \\
\hline \multirow[t]{2}{*}{ GA-WH-OT-4 } & $\begin{array}{l}\text { Southern Natural Gas Co., } \\
\text { Dr. D. B. McRae } \$ 1\end{array}$ & $32^{\circ} 02^{\prime} 68^{\prime \prime}$ & $828^{\prime} 8^{\prime} 42^{\prime}$ & 175 & 164 & 3,643 & - & - & - & - & 3,035 & $>433$ \\
\hline & & \multicolumn{11}{|c|}{ Brunswick County, N.C. } \\
\hline NC-BR-T-7 & $\begin{array}{l}\text { N.C. Division of Water } \\
\text { Resources, Calabash- } \\
\text { Test } \$ 1,1972\end{array}$ & $33^{\circ} 53^{\prime} 35^{\prime \prime}$ & $78^{\circ} 35^{\prime} 20^{\prime \prime}$ & 48 & 48 & 1,335 & abs. & - & abs. & - & 1,124 & 163 \\
\hline
\end{tabular}

\begin{tabular}{|c|c|c|c|c|c|c|c|c|c|c|c|}
\hline & & & & & & $\operatorname{sen} \mathrm{C}$ & & & & & \\
\hline AK-P- & $\begin{array}{l}\text { Layne Atlantic, } \\
\text { City of Aiken, } 1953\end{array}$ & $33^{\circ} 31^{\prime} 45^{\prime \prime}$ & $81^{\circ} 42^{\prime} 30^{\circ}$ & 480 & 480 & 519 & abs. & - & abs. & - & +295 \\
\hline
\end{tabular}

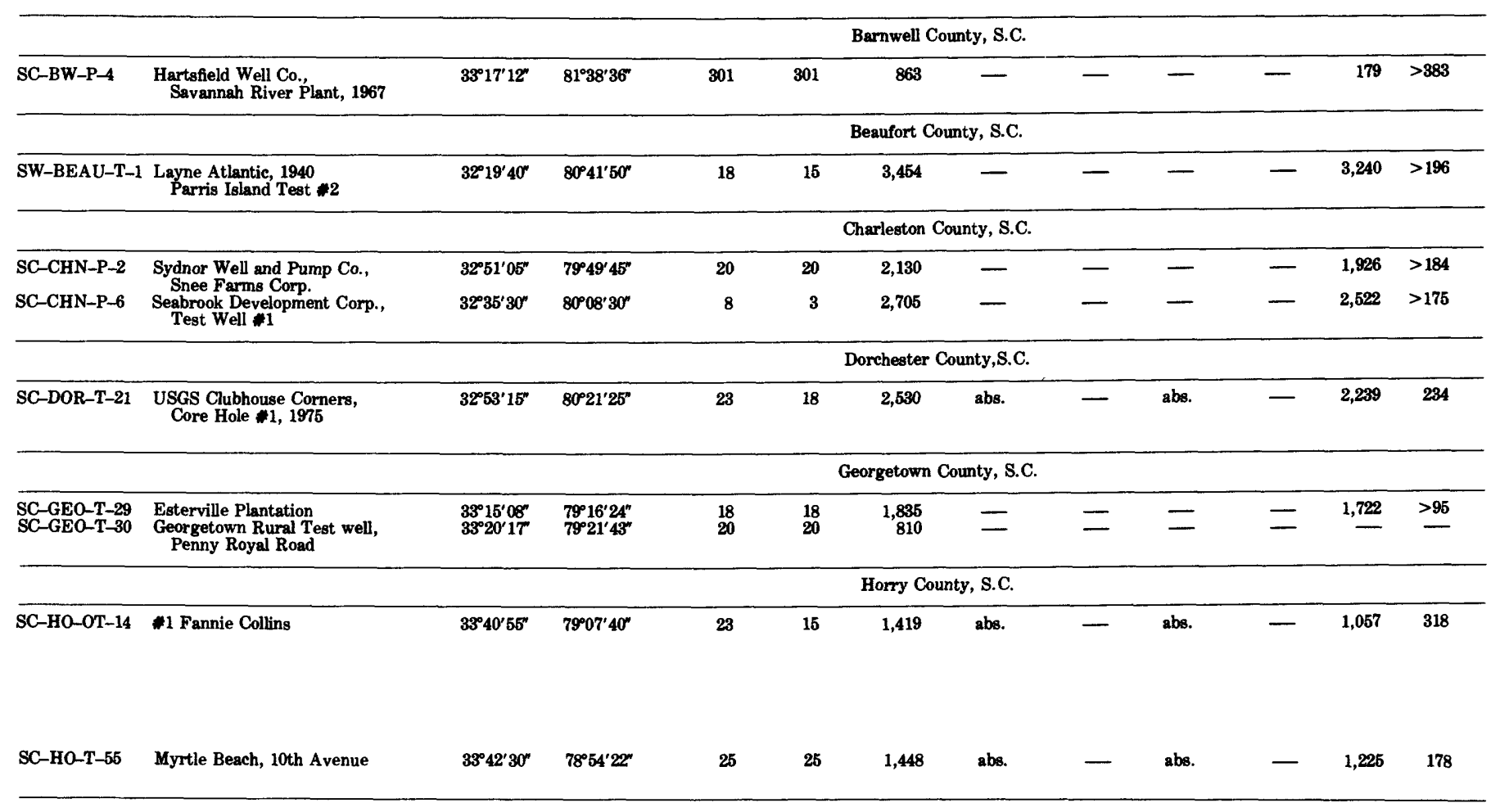


data for the 88 wells that make up the key-well network-Continued

\begin{tabular}{|c|c|c|c|c|c|c|c|c|c|c|c|c|}
\hline \multirow[b]{2}{*}{ Well number } & \multirow[b]{2}{*}{ Well name } & \multicolumn{2}{|c|}{ Unit $\mathbf{E}$} & \multicolumn{2}{|c|}{ Unit $D$} & \multicolumn{2}{|c|}{ Unit $\mathrm{C}$} & \multicolumn{2}{|c|}{ Unit B } & \multicolumn{2}{|c|}{ Unit A } & \multirow[b]{2}{*}{ Remarks } \\
\hline & & $\begin{array}{l}\text { Depth to } \\
\text { top below } \\
\text { mean sea } \\
\text { level }(\mathrm{ft})\end{array}$ & $\begin{array}{c}\text { Thickness } \\
\text { (ft) }\end{array}$ & $\begin{array}{l}\text { Depth to } \\
\text { top below } \\
\text { mean sea } \\
\text { level (ft) }\end{array}$ & $\begin{array}{l}\text { Thickness } \\
\text { (ft) }\end{array}$ & $\begin{array}{l}\text { Depth to } \\
\text { top below } \\
\text { mean sea } \\
\text { level }(\mathrm{ft})\end{array}$ & $\begin{array}{l}\text { Thickness } \\
\text { (ft) }\end{array}$ & $\begin{array}{l}\text { Depth to } \\
\text { top below } \\
\text { mean sea } \\
\text { level }(\mathrm{ft})\end{array}$ & $\begin{array}{l}\text { Thickness } \\
\text { (ft) }\end{array}$ & $\begin{array}{l}\text { Depth to } \\
\text { top below } \\
\text { mean sea } \\
\text { level (ft) }\end{array}$ & $\begin{array}{l}\text { Thickness } \\
\text { (ft) }\end{array}$ & \\
\hline & & & \multicolumn{10}{|c|}{ Wheeler County, Ga. } \\
\hline GA-WH-OT-1 & $\begin{array}{l}\text { T. R. Davis \& Assoc., } \\
\text { Jordan Heirs No. } 1\end{array}$ & 2,967 & 103 & 2,755 & 212 & 2,347 & 408 & 2,025 & 322 & 1,585 & 440 & $\begin{array}{l}\text { Section } \mathbf{E}-\mathbf{E}^{\prime} \\
\text { Top, Triassic(?), below } \\
\text { mean sea level } \\
\text { (feet): } \mathbf{3}, \mathbf{5 0 9}\end{array}$ \\
\hline GA-WH-OT-2 & $\begin{array}{l}\text { Parsons, } \\
\text { No. } 1 \text { Clyde E. Hinson }\end{array}$ & 2,764 & 125 & 2,494 & 270 & 2,166 & 328 & 1,799 & 367 & 1,517 & 282 & $\begin{array}{l}\text { Section D-D' } \\
\text { Top, Triassic(?), below } \\
\text { mean sea level } \\
\text { (feet): } \mathbf{3 , 2 1 4}\end{array}$ \\
\hline GA-WH-OT-3 & $\begin{array}{l}\text { Southern Natural Gas Co., } \\
\text { Ronnie Towns } \# 1\end{array}$ & 2,911 & 142 & 2,686 & 225 & 2,431 & 255 & 2,041 & 390 & 1,711 & 330 & $\begin{array}{l}\text { Top, Triassic(?), below } \\
\text { mean sea level } \\
\text { (feet): } \mathbf{3 , 6 5 1}\end{array}$ \\
\hline \multirow[t]{2}{*}{ GA-WH-OT-4 } & $\begin{array}{l}\text { Southern Natural Gas Co., } \\
\text { Dr. D. B. McRae } \# 1\end{array}$ & 2,900 & 135 & 2,680 & 220 & 2,345 & 335 & 2,005 & 340 & 1,675 & 330 & \\
\hline & & & \multicolumn{10}{|c|}{ Brunswick County, N.C. } \\
\hline \multirow[t]{2}{*}{ NC-BR-T-7 } & $\begin{array}{l}\text { N.C. Division of Water } \\
\text { Resources, Calabash- } \\
\text { Test } * 1,1972\end{array}$ & abs. & - & 944 & 180 & 630 & 314 & 352 & 278 & 12 & 340 & $\begin{array}{l}\text { Section A-A' } \\
\text { Top, pre-Cretaceous } \\
\text { crystalline rock, below } \\
\text { mean sea level } \\
\text { (feet): } 1,287\end{array}$ \\
\hline & & & \multicolumn{10}{|c|}{ Aiken County, S.C. } \\
\hline \multirow[t]{2}{*}{ SC-AK-P-1 } & $\begin{array}{l}\text { Layne Atlantic, } \\
\text { City of Aiken, } 1953\end{array}$ & abs. & - & +385 & 90 & abs. & - & abs. & - & abs. & - & $\begin{array}{l}\text { Section B-B' } \\
\text { Top, pre-Cretaceous } \\
\text { crystalline rock, below } \\
\text { mean sea level } \\
\text { (feet): } 39\end{array}$ \\
\hline & & & \multicolumn{10}{|c|}{ Barnwell County, S.C. } \\
\hline \multirow[t]{2}{*}{ SC-BW-P-4 } & $\begin{array}{l}\text { Hartsfield Well Co., } \\
\text { Savannah River Plant, } 1967\end{array}$ & abs. & - & 31 & 148 & abs. & - & abs. & - & abs. & - & Section B-B' \\
\hline & & & \multicolumn{10}{|c|}{ Beaufort County, S.C. } \\
\hline \multirow[t]{2}{*}{ SW-BEAU-T-1 } & $\begin{array}{l}\text { Layne Atlantic, } 1940 \\
\text { Parris Island Test } \% 2\end{array}$ & 3,122 & 188 & 2,509 & 613 & 2,187 & 322 & 1,612 & 575 & 1,247 & 365 & Section $\mathbf{A}-\mathbf{A}^{\prime}$ \\
\hline & & & \multicolumn{10}{|c|}{ Charleston County, S.C. } \\
\hline SC-CHN-P-2 & $\begin{array}{l}\text { Sydnor Well and Pump Co., } \\
\text { Snee Farms Corp. }\end{array}$ & abs. & - & 1,616 & 310 & 1,244 & 372 & 912 & 332 & 622 & 290 & Section $\mathbf{A}-\mathbf{A}^{\prime}$ \\
\hline \multirow[t]{2}{*}{ SC-CHN-P-6 } & $\begin{array}{l}\text { Seabrook Development Corp., } \\
\text { Test well } \# 1\end{array}$ & abs. & - & 2,008 & 514 & 1,642 & 366 & 1,184 & 458 & 842 & 342 & Section $\mathbf{A}-\mathbf{A}^{\prime}$ \\
\hline & & & \multicolumn{10}{|c|}{ Dorchester County, S.C. } \\
\hline \multirow[t]{2}{*}{ SC-DOR-T-21 } & $\begin{array}{l}\text { USGS Clubhouse Corners, } \\
\text { Core Hole } \# 1,1975\end{array}$ & abs. & - & 1,837 & 402 & 1,517 & 320 & 1,077 & 440 & 777 & 300 & $\begin{array}{l}\text { Top, Triassic(?), below } \\
\text { mean sea level } \\
\text { (feet): } 2,473\end{array}$ \\
\hline & & & \multicolumn{10}{|c|}{ Georgetown County, S.C. } \\
\hline \multirow[t]{2}{*}{$\begin{array}{l}\text { SC-GEO-T-29 } \\
\text { SC-GEO-T-30 }\end{array}$} & $\begin{array}{l}\text { Esterville Plantation } \\
\text { Georgetown Rural Test well, } \\
\text { Penny Royal Road }\end{array}$ & abs. & $=$ & $\underline{1,422}$ & $\underline{300}$ & 1,082 & 340 & $\begin{array}{l}740 \\
665\end{array}$ & $\begin{array}{r}342 \\
>125\end{array}$ & $\begin{array}{l}360 \\
225\end{array}$ & $\begin{array}{l}380 \\
440\end{array}$ & Section A-A $\mathbf{A}^{\prime}$ \\
\hline & & & \multicolumn{10}{|c|}{ Horry County, S.C. } \\
\hline SC-HO-OT-14 & \#1 Fannie Colhns & abs. & - & 897 & 160 & 647 & 250 & 379 & 268 & 47 & 332 & $\begin{array}{l}\text { Top, pre-Cretaceous } \\
\text { crystalline rock, below } \\
\text { mean sea level } \\
\text { (feet): } 1,375\end{array}$ \\
\hline SC-HO-T-55 & Myrtle Beach, 10th Avenue & abs. & - & 1,023 & 202 & 717 & 306 & 431 & 286 & 23 & 408 & $\begin{array}{l}\text { Section } \mathbf{A - \Lambda ^ { \prime }} \\
\text { Top, pre-cretaceous } \\
\text { crystalline rock (?), } \\
\text { below mean sea level } \\
\text { (feet) } 1,403\end{array}$ \\
\hline
\end{tabular}


TABLE 7.-Geohydrologic data for the 18 wells judged to have waste-storage potential

Unit A

Potential reservoir sand determination

Well number

GA-GLY-OT-7

Depth to top of unit (MSL)

Thickness of unit (feet)

Unit's total sand thickness (feet/perce

Unit's total shale thickness (feet/percent)

Unit's sand-shale ratio

Number of potential reservoir sands in unit

Total thickness (feet) of unit's potential reservoir sands -

Average thickness (feet) of unit's potential reservoir sands

Maximum thickness (feet) of a potential reservoir sand layer in unit --..-.

Ratio - unit's potential reservoir sand thickness: umit's total thickness _._._._._._._._._.

Ratio-umit's potential reservoir thickness: unit's total sand thickness

Thickness (feet)-Immediately underlying shale seal-potential reservoir

sand-immediately overlying shale seal

Ratio (feet)-Thickness of immediately underlying shale seal: thickness of potential

reservoir sand: thickness of immediately overlying shale seal-

Depth to top of uppermost potential reservoir sand (MSL)

Depth to top of lowermost potential reservoir sand (MSL)

Average depth to top of unit's potential reservoir sand (MSL)

Percent of potential reservoir sand in upper third of unit -

Percent of potential reservoir sand in middle third of unit

Percent of potential reservoir sand in lower third of unit

$\mathrm{D} / \mathrm{PR}$ factor (average depth of potential reservoir sand occurrence/total

thickness of unit's potential reservoir sand)-

Average sodium chloride in $\mathrm{mg} / \mathrm{L}$

Average depth (feet)

$-2,346$

925

$155 / 17$

40043

0.4

1

155

155

.17

1

42-155-205

$0.27: 1: 1.32$

3,116

3,116

3,116

0

100

20

10.2

\section{Unit B}

Potential reservoir sand determination

Well number

GA-CAM-OT-1

Depth to top of unit (MSL)

Thickness of unit (feet)

Unit's total shale thickness (feet/percent)

Unit's sand-shale ratio

Number of potential reservoir sands in unit

Total thickness (feet) of unit's potential reservoir sand

Average thickness (feet) of unit's potential reservoir sands

in thess (feet) of a potential reservoir sand layer in unit

Ratio-unit's potential reservoir sand thickness: unit's total thickness

Ratio-unit's potential reservoir thickness: unit's total sand thickness -

Thickness (feet)-Immediately underlying shale seal-potential reservoir sand-immediately overlying shale seal

Ratio (feet)-Thickness of immediately underlying shale seal: thickness of potential

reservoir sand: thickness of immediately overlying shale seal-

Depth to top of uppermost potential reservoir sand (MSL)

Depth to top of lowermost potential reservoir sand (MSL)

Average depth to top of unit's potential reservoir sand (MSL)

Percent of potential reservoir sand in upper third of unit -

Percent of potential reservoir sand in middle third of unit

Percent of potential reservoir sand in lower third of unit

D/PR factor (average depth of potential reservoir sand occurrence/total thickness of unit's potential reservoir sand)

Average sodium chloride in $\mathrm{mg} / \mathrm{L}$

$-\mathbf{3 , 3 1 5}$

310

$195 / 63$

$115 / 37$

1.7

195

195

195

0.63

1

$95-195-80$

0.49:1:0.41

3,415

3,415

3,415

2

17.5

11.9

Average depth (feet) 
TABLE 7.-Geohydrologic data for the 18 wells judged to have waste-storage potential-Continued

Unit D

\begin{tabular}{|c|c|c|c|}
\hline \multirow[t]{2}{*}{ Potential reservoir sand determination } & \multicolumn{3}{|c|}{ Well number } \\
\hline & GA-CAM-OT-1 & GA-EC-OT-1 & GA-GLY-OT-2 \\
\hline Depth to top of unit (MSL) -.. & $-4,070$ & $-3,124$ & $-4,080$ \\
\hline Thickness of unit (feet) & 267 & 200 & 395 \\
\hline Unit's total sand thickness (feet/percent) - & $85 / 32$ & $85 / 42$ & 18145 \\
\hline Unit's total shale thickness (feet/percent) & $182 / 68$ & $115 / 58$ & $214 / 55$ \\
\hline Unit's sand-shale ratio & 0.5 & 0.7 & 0.8 \\
\hline Number of potential reservoir sands in unit & 1 & 1 & 1 \\
\hline Total thickness (feet) of unit's potential reservoir sands & 85 & 85 & 100 \\
\hline Average thickness (feet) of unit's potential reservoir sands- & 85 & 85 & 100 \\
\hline Maximum thickness (feet) of a potential reservoir sand layer in unit & 85 & 85 & 100 \\
\hline Ratio-unit's potential reservoir sand thickness: unit's total thickness & 0.32 & 0.4 & 0.25 \\
\hline Ratio-unit's potential reservoir thickness: unit's total sand thickness & 1 & 1 & 0.55 \\
\hline \multirow{2}{*}{\multicolumn{4}{|c|}{ 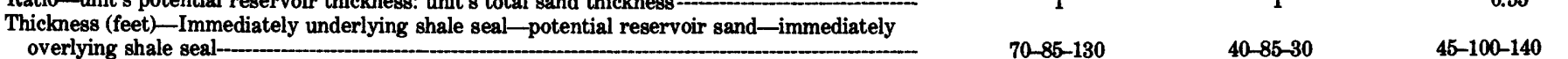 }} \\
\hline & $70-85-130$ & $40-85-30$ & $45-100-140$ \\
\hline \multicolumn{4}{|l|}{ Ratio (feet)-Thickness of immediately underlying shale seal: thickness of potential } \\
\hline reservoir sand: thickness of immediately overlying shale seal-- & 0.82:1:1.5 & $0.47: 1: 0.35$ & $0.45: 1: 1.4$ \\
\hline Depth to top of uppermost potential reservoir sand (MSL) & 4,075 & 3,114 & 4,080 \\
\hline Depth to top of lowermost potential reservoir sand (MSL) - & 4,075 & 3,114 & 4,080 \\
\hline Average depth to top of unit's potential reservoir sand (MSL) - & 4,075 & 3,114 & 4,080 \\
\hline Percent of potential reservoir sand in upper third of unit - & 100 & 78 & 100 \\
\hline Percent of potential reservoir sand in middle third of unit & 0 & 22 & $\mathbf{0}$ \\
\hline Percent of potential reservoir sand in lower third of unit & 0 & $\mathbf{0}$ & 0 \\
\hline \multicolumn{4}{|l|}{ D/PR factor (average depth of potential reservoir sand occurrence/total thickness of unit's } \\
\hline potential reservoir sand) & 48 & 37 & 41 \\
\hline Average sodium chloride in $\mathrm{mg} / \mathrm{L}$ & 12.1 & 12.4 & 12.7 \\
\hline Average depth (feet) & & & \\
\hline
\end{tabular}

\section{Unit $\mathbf{E}$}

Potential reservoir sand determination

Well number

GA-COQ-OT-1

GA-EA-OT-1

Depth to top of unit (MSL)

Thickness of unit (feet)

Unit's total sand thickness (feet/percent)

Unit's total shale thickness (feet/percent)

Unit's sand-shale ratio

Number of potential reservoir sands in unit

Total thickness (feet) of unit's potential reservoir sands

Average thickness (feet) of unit's potential reservoir sands

Maximum thickness (feet) of a potential reservoir sand layer in unit

Ratio-unit's potential reservoir sand thickness: unit's total thickness

Ratio-unit's potential reservoir thickness: unit's total sand thickness

Thickness (feet)-Immediately underlying shale seal-potential reservoir sand-immediately

overlying shale seal

Ratio (feet)-Thickness of immediately underlying shale seal: thickness of potential

reservoir sand: thickness of immediately overlying shale seal-

Depth to top of uppermost potential reservoir sand (MSL)

Depth to top of lowermost potential reservoir sand (MSL)

Average depth to top of unit's potential reservoir sand (MSL)

Percent of potential reservoir sand in upper third of unit-

Percent of potential reservoir sand in middle third of unit

Percent of potential reservoir sand in lower third of unit

D/PR factor (average depth of potential reservoir sand occurrence/total thickness of unit's potential reservoir sand)

Average sodium chloride in $\mathrm{mg} / \mathrm{L}$

$\begin{array}{cc}-3,040 & -2,738 \\ 200 & 215 \\ 58 / 29 & 4019 \\ 142 / 71 & 175 / 81 \\ 0.4 & 0.2 \\ 1 & 1 \\ 58 & 40 \\ 58 & 40 \\ 58 & 40 \\ .29 & 1 \\ 1 & \\ & 50-40-33 \\ 20-58-34 & \\ & 1.25: 1: 0.6 \\ 0.35: 1: 0.59 & 2,898 \\ 3,174 & 2,898 \\ 3,174 & 2,898 \\ 3,174 & 0 \\ 0 & 0 \\ 10 & 100 \\ 90 & \\ & 72 \\ 55 & 3.9 \\ 23.8 & \end{array}$

Average depth (feet) 
TABLE 7.-Geohydrologic data for the 18 wells judged to have waste-storage potential-Continued

Unit F

\begin{tabular}{|c|c|c|c|}
\hline \multirow[t]{2}{*}{ Potential reservoir sand determination } & \multicolumn{3}{|c|}{ Well number } \\
\hline & GA-AT-OT-1 & GA-DE-OT-1 & GA-DOG-OT-2 \\
\hline Depth to top of unit (MSL) - & $-3,777$ & $-3,383$ & $-2,803$ \\
\hline Thickness of unit (feet) & 222 & 1,213 & 1,210 \\
\hline Unit's total sand thickness (feet/percent) -... & 10849 & $841 / 69$ & $950 / 79$ \\
\hline Unit's total shale thickness (feet/percent) --. & $114 / 51$ & $372 / 31$ & $260 / 21$ \\
\hline Unit's sand-shale ratio & 0.9 & 2.3 & 3.6 \\
\hline Number of potential reservoir sands in unit & 1 & 1 & 1 \\
\hline Total thickness (feet) of unit's potential reservoir sands & 42 & 62 & 42 \\
\hline Average thickness (feet) of unit's potential reservoir sands- & 42 & 62 & 42 \\
\hline Maximum thickness (feet) of a potential reservoir sand layer in unit --. & 42 & 62 & 42 \\
\hline Ratio - unit's potential reservoir sand thickness: unit's total thickness -- & 0.19 & 0.05 & 0.03 \\
\hline Ratio-unit's potential reservoir thickness: unit's total sand thickness - & 0.39 & 0.07 & 0.04 \\
\hline \multicolumn{4}{|l|}{ Thickness (feet)-Immediately underlying shale seal-potential reservoir sand-immediately } \\
\hline \multicolumn{4}{|l|}{ Ratio (feet)-Thickness of immediately underlying shale seal: thickness of potential } \\
\hline reservoir sand: thickness of immediately overlying shale seal & 0.71:1:0.48 & $0.97: 1: 0.65$ & 0.55:1:0.71 \\
\hline Depth to top of uppermost potential reservoir sand (MSL) - & 3,885 & 4,214 & 2,833 \\
\hline Depth to top of lowermost potential reservoir sand (MSL) & 3,885 & 4,214 & 2,833 \\
\hline Average depth to top of unit's potential reservoir sand (MSL) & 3,885 & 4,214 & 2,833 \\
\hline Percent of potential reservoir sand in upper third of unit - & $\mathbf{0}$ & 0 & 100 \\
\hline Percent of potential reservoir sand in middle third of unit & 95 & 0 & 0 \\
\hline Percent of potential reservoir sand in lower third of unit - & 5 & 100 & $\mathbf{0}$ \\
\hline \multicolumn{4}{|l|}{ D/PR factor (average depth of potential reservoir sand occurrence/total thickness of unit's } \\
\hline 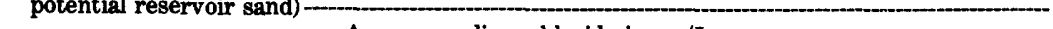 & 92 & 68 & 67 \\
\hline Average sodium chloride in $\mathrm{mg} / \mathrm{L}$ & 19.2 & 15.9 & - \\
\hline Average depth (feet) & & & \\
\hline
\end{tabular}

\section{Unit F}

Potential reservoir sand determination

Well number

GA-EA-OT-1

GA-EA-OT-2

GA-EA-OT-3

Depth to top of unit (MSL)

Thickness of unit (feet)

Unit's total sand thickness (feet/percent)

Unit's total shale thickness (feet/percent)

Unit's sand-shale ratio -

Number of potential reservoir sands in unit

Total thickness (feet) of unit's potential reservoir sands

Average thickness (feet) of unit's potential reservoir sands

Maximum thickness (feet) of a potential reservoir sand layer in unit

Ratio-unit's potential reservoir sand thickness: unit's total thickness

Ratio-unit's potential reservoir thickness: unit's total sand thickness

Thickness (feet)-Immediately underlying shale seal-potential reservoir sand-immediately

overlying shale seal-

Ratio (feet)—Thickness of immediately underlying shale seal: thickness of potential reservoir sand: thickness of immediately overlying shale seal

Depth to top of uppermost potential reservoir sand (MSL)

Depth to top of lowermost potential reservoir sand (MSL)

Average depth to top of unit's potential reservoir sand (MSL)

Percent of potential reservoir sand in upper third of unit

Percent of potential reservoir sand in middle third of unit

Percent of potential reservoir sand in lower third of unit -

D/PR factor (average depth of potential reservoir sand occurrence/total thickness of unit's potential reservoir sand)

\section{Average sodium chloride in $\mathrm{mg} / \mathrm{L}$} Average depth (feet)
$-2,953$

1,560

$890 / 57$

$670 / 43$

1.3

1

50

50
50

50

0.03

0.06

44-50-30

$-2,996 \quad-2,955$

$1,530 \quad 1,555$

$1,208 / 80$

$\begin{array}{rr}1,228 / 80 & 788 / 51 \\ 302 / 20 & 767 / 49\end{array}$

4.1

2

79

39.5

0.05

0.06

1.0

1

58
58

58

0.04

0.07

4-54-38

43-58-20

23-25-24

$0.88: 1: 0$.
3,683
3,683
3,683
0
100
0
74
12

0.44:1:0.7

0.92:1:0.96

3,762

3,840

3,801

0

100
0

48.1

$0.74: 1: 0.34$

3,686

3,686

3,686

0
100

100
0

64

12.9

17.2 
TABLE 7.-Geohydrologic data for the 18 wells judged to have waste-storage potential-Continued

Potential reservoir sand determination

Well Number

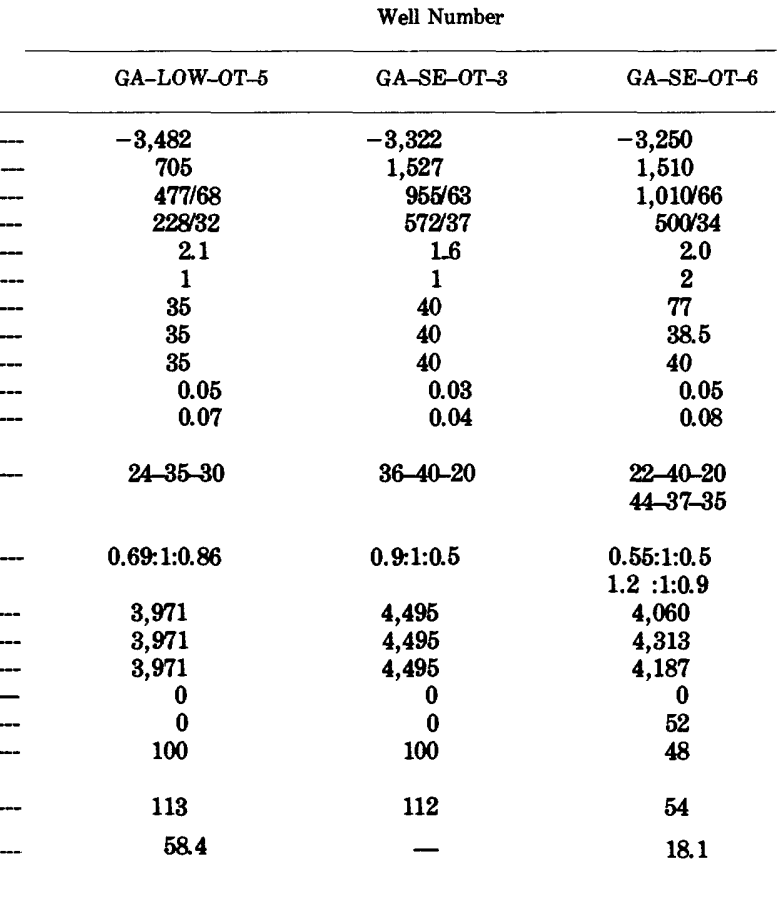

Depth to top of unit (MSL)

Thickness of unit (feet)

Unit's total sand thickness (feet/percent)

Unit's total shale thickness (feet/percent)

Unit's sand-shale ratio

Number of potential reservoir sands in unit

Total thickness (feet) of unit's potential reservoir sands

Average thickness (feet) of unit's potential reservoir sands

Maximum thickness (feet) of a potential reservoir sand layer in unit

Ratio-unit's potential reservoir sand thickness: unit's total thickness

Ratio-unit's potential reservoir thickness: unit's total sand thickness

Thickness (feet)-Immediately underlying shale seal-potential reservoir sand-immediately overlying shale seal

Ratio (feet)-Thickness of immediately underlying shale seal: thickness of potential reservoir sand: thickness of immediately overlying shale seal-

Depth to top of uppermost potential reservoir sand (MSL)

Depth to top of lowermost potential reservoir sand (MSL)

Percent of potential reservoir sand in upper third of unit

Percent of potential reservoir sand in middle third of unit

Percent of potential reservoir sand in lower third of unit

D/PR factor (average depth of potential reservoir sand occurrence/total thickness of unit's potential reservoir sand)

Average sodium chloride in $\mathrm{mg} / \mathrm{L}$ Average depth (feet)
Average depth to top of unit's potential reservoir sand (MSL)

\section{Unit $F$}


TABLE 7.-Geohydrologic data for the 18 wells judged to have waste-storage potential-Continued

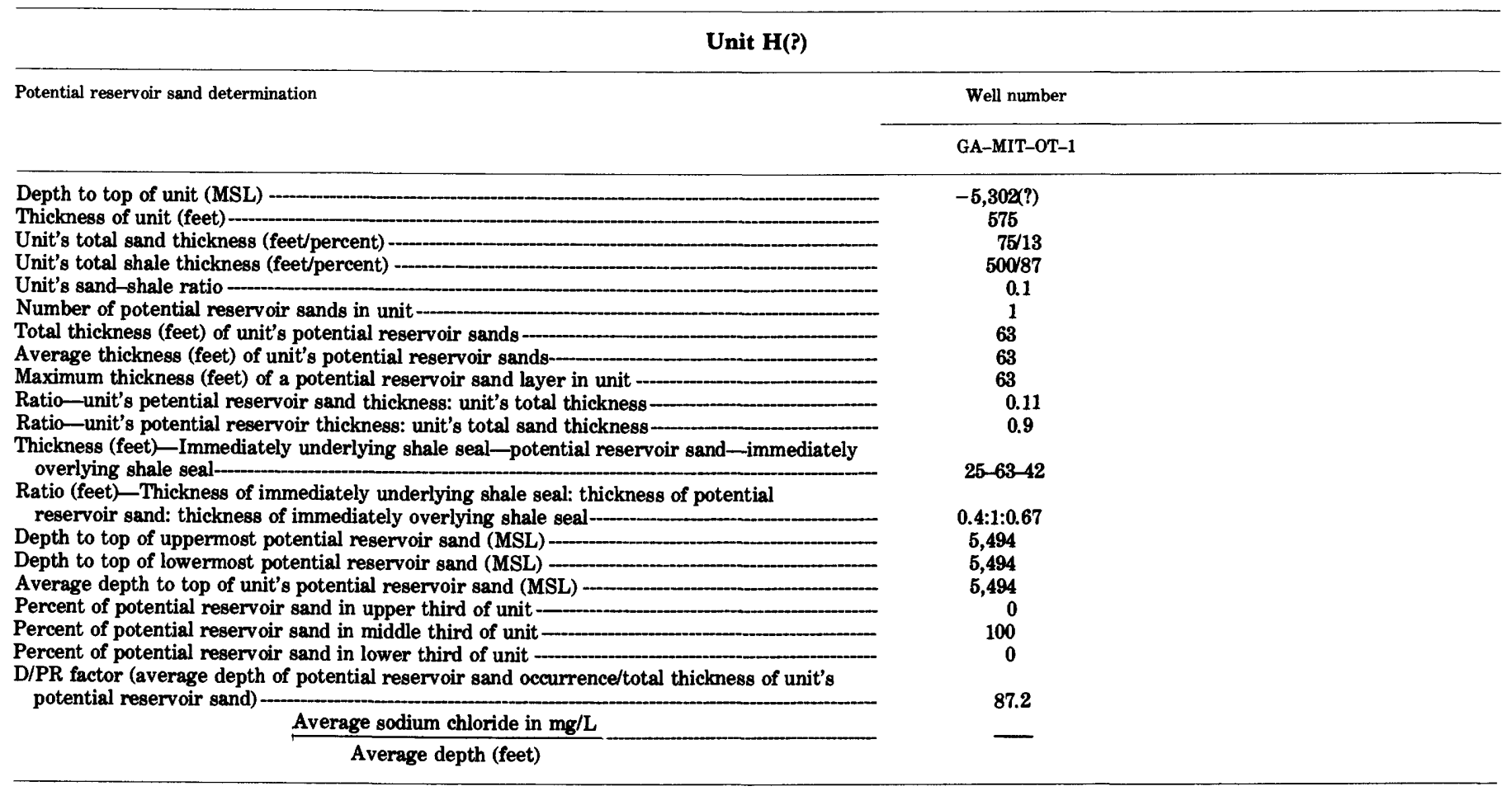

TABLE 8.-Approximate sodium chloride concentration of ground water in Units A through H(?) in wells forming the key-well network

[C, data calculated; D, data from drill stem test]

\begin{tabular}{|c|c|c|c|c|c|c|c|}
\hline Well number & Unit & $\begin{array}{l}\text { Depth interval, } \\
\text { feet below mean } \\
\text { sea level }\end{array}$ & $\begin{array}{l}\text { Concentration of } \\
\text { sodium chloride } \\
\text { (NaCl) in forma- } \\
\text { tion water, in } \\
\text { milligrams per } \\
\text { liter }\end{array}$ & Well number & Unit & $\begin{array}{l}\text { Depth interval, } \\
\text { feet below mean } \\
\text { sea level }\end{array}$ & $\begin{array}{l}\text { Concentration of } \\
\text { sodium chloride } \\
\text { (NaCl) in forma- } \\
\text { tion water, in } \\
\text { milligrams per } \\
\text { liter }\end{array}$ \\
\hline
\end{tabular}


TABLE 8.-Approximate sodium chloride concentration of ground water in Units A through H(?) in wells forming the key-well network Continued

\begin{tabular}{|c|c|c|c|c|c|c|c|}
\hline Well number & Unit & $\begin{array}{l}\text { Depth interval, } \\
\text { feet below mean } \\
\text { sea level }\end{array}$ & $\begin{array}{l}\text { Concentration of } \\
\text { sodium chloride } \\
\text { (NaCl) in forma- } \\
\text { tion water, in } \\
\text { milligrams per } \\
\text { liter }\end{array}$ & Well number & Unit & $\begin{array}{l}\text { Depth interval, } \\
\text { feet below mean } \\
\text { sea level }\end{array}$ & $\begin{array}{l}\text { Concentration of } \\
\text { sodium chloride } \\
\text { (NaCl) in forma- } \\
\text { tion water, in } \\
\text { milligrams per } \\
\text { liter }\end{array}$ \\
\hline
\end{tabular}

